\title{
Re-approaching Celts: Origins, Society, and Social Change
}

\author{
Rachel Pope ${ }^{1}$
}

Accepted: 9 February 2021 / Published online: 24 March 2021

(c) The Author(s) 2021

\begin{abstract}
This work re-approaches the origins of "the Celts" by detailing the character of their society and the nature of social change in Europe across 700-300 BC. A new approach integrates regional burial archaeology with contemporary classical texts to further refine our social understanding of the European Iron Age. Those known to us as "Celts" were matrifocal Early Iron Age groups in central Gaul who engaged in social traditions out of the central European salt trade and became heavily involved in Mediterranean politics. The paper focuses on evidence from the Hallstatt-La Tène transition to solve a 150-year-old problem: how the Early Iron Age "Celts" became the early La Tène "Galatai," who engaged in the Celtic migrations and the sacking of Rome at 387 BC.
\end{abstract}

Keywords Celts $\cdot$ Archaeological method $\cdot$ Vix $\cdot$ Galatai $\cdot$ Gaul $\cdot$ Herodotus

\section{Introduction}

A good place to begin is to state what this paper on Iron Age "Celts" does not do. I do not address modern "Celtic" identity (see Collis 2017; James 1999), nor do I consider "Celts" of the early medieval period (papers in Karl and Stifter 2007) each has relatively little to do with the task of understanding the people of Iron Age Europe. I do touch briefly on "Celtic" language, where the archaeology allows it, and I hope that this work, in combining archaeology and historical texts, will assist those interested in Celtic linguistics. My primary aim is to further refine our

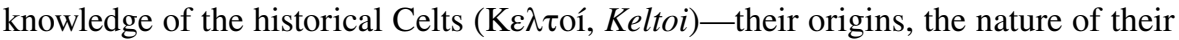
society (plural), and social change (between 700 and 300 BC). To this end, I use a large dataset and new method to produce an evidence-based narrative, one that foregrounds chronology, regional archaeological traditions, and the integration of evidence from contemporary historical texts. My aim is to more closely define what

Rachel Pope

rachel.pope@liverpool.ac.uk

1 Department of Archaeology, Classics, and Egyptology, University of Liverpool, 12-14

Abercromby Square, Liverpool L69 7WZ, UK 
was meant in those first uses of the word "Celt," which should assist in understanding its continued use through time. First, I must set out the inherited problem.

The origin of "the Celts" is a problem that has eluded resolution for over 150 years, as "impossible" and "lost in the mists of time" (Chadwick 1971; Duval 1997; Karl 2012; Pauli 1980). For this author, however, the problem lies only in how we have approached the evidence. Our main setback has been a reading of the historical sources that lacks temporal context. Previous narratives on the Celts (singular) see a mixing together of classical ideas on "Celts" from across 1000 years (see Stopford 1987). The result is construction of a static, romantic notion of "Celtic society" operating independently of regional-level archaeologies. Instead, on the basis of broad-brush similarities in material culture, a pan-European "Celtic culture" continues to be imagined across Europe, acting historically via events-in-time mentioned in the texts (e.g., Cunliffe 2019a; Cunliffe and Koch 2012, 2013; Hornblower et al. 2012). This historicist narrative of "the Celts" has then been linked to an equally fossilized Celtic linguistics that operates at a similar geographical scale, which has led to the retention of outdated notions of cultural diffusionism (see Karl 2012). Despite archaeological thinking moving against this early 20th century practice, both in the 1950s-1960s and again in the 1980s (see below), mainstream scholarship continued to accept "Celt" in its early first millennium AD romantic state to fit the final linguistic spread.

Unfortunately, this old thinking on "cultures" has also reemerged in European Bronze Age studies, where the scientific term "population replacement"-innocent enough in research with aDNA datasets-has been applied culturally, leading to simplistic narratives of Beaker/Yamnaya invasion and intercultural violence. The method and ethics of such work, where material culture distributions, or language, or aDNA is mapped onto ideas of ethnicity or nation-states/empire/culture is not only methodologically unsound, it is anachronistic and politically dangerous (Booth 2019; Collis 2019; Furholt 2018; Hakenbeck 2019; Heyd 2017; Saini 2019). Here, I follow Collis (1996) and Feinman and Neitzel (2020) in explicitly rejecting notions of cultures and attempts to determine ethnicity that seek to elucidate large-scale, bounded entities in the archaeological material. It is clear that these large-scale distributions represent fossilized and artificial social datasets over deep time. The "spread" is an artifact of hindsight and exists only through the medium of our own study; it does not in any real sense belong to the past. Broad similarities in material culture over large geographical areas do not make those groups the same; ideas travel further than people. Clarke (1968) was very clear that different data categories (material culture types, language, aDNA) each diverge in the scale of their reach and overlap and are not coherent signatures of "culture." It is hard to understand how this fundamental learning on the nature of our data has been lost by some of our most senior archaeologists.

Our problem, then, in seeking to understand the nature of later European prehistoric society has primarily been one of scale and data resolution. Over the last 150 years, archaeology has been a struggle, through the generations, between those who accept large-scale cultures and grand narrative (historicist method, broad-brush material culture distributions, linguistic spreads) and those who seek instead to determine "regional characteristics" in the archaeology (Bertrand 1876, Cunnington 
1923, Clarke 1968; Kenyon 1952). In this paper, I try something that might bring the two schools together by building social narrative out of regional archaeological characteristics and historical sources, via method that centers temporal context.

I argue here that overturning 20th century romanticism-"Celts" as an inherited historical/mythical conglomeration - and completing archaeology's 1960s-1980s paradigm shift lies in all archaeologists working to build contextual method. Our quest to understand past people, scientifically, requires a local/regional analytical focus from which we can provide broader synthesis. I seek to develop the idea that modern archaeological studies must center contextual practice. Context is achieved temporally (refining chronologies, sequencing data-a stratigraphy almost) alongside accepting cultural particularism (via unbounded, regional traditions-a route in, at present, to what are actually smaller-scale social groups). An older generation of social narrative that lacked temporal context has overlooked critical social information in the archaeology itself and instead imposed typically Roman or early medieval social forms onto prehistory (via analogy from first millennium AD textual sources and abstract social modeling). The move now is toward reconstructing past societies (plural) from the archaeological data by seeking to achieve greater contextual resolution (temporal and spatial) that moves us toward identifying generational, local/regional social forms, their temporalities, and the mechanisms of social change. This will require new learning on social networks and anthropologies of kinship, as well as archaeological work on mobility (Clarke and Haraway 2018; Latour 2005; Strathern 2020), to understand the various scales and temporalities at which people interact across space. I offer this work as an example of how we can begin doing this. Where better to begin applying new method than to the "impossible" question of origins.

To situate the research, I begin the paper with a potted history of thinking on Iron Age Celts, from the 19th century to present day (see also Collis 2003), bringing us up to date with current objectives in archaeology more generally. The methodology section details how archaeological data were chosen and approached to improve the quality of social information, as well as the method for contextualizing and integrating the historical sources. The majority of the paper is a chronological narrative, developed from the sequenced archaeological and historical data, for 700-300 BC. First, I detail the historical and archaeological evidence for the seventh and sixth centuries $\mathrm{BC}$, encountering the Celts in the era of a burgeoning salt trade out of Austria. The second section discusses 550-450 BC, when Europe was politically involved with the Mediterranean, with unrest among the "Galatai"-resolved here as the historically distinct descendants of the Celts - and the decline of the Hallstatt era at $450 \mathrm{BC}$. The final section focuses on $450-300 \mathrm{BC}$, the period surrounding the "Celtic migrations" and the 387 BC attack on Rome; here I use texts and archaeology to discover how ancient writers understood/documented "the Celts." I then discuss what has been revealed about Iron Age Celts and conclude by reflecting on how the application of new method brings new information. 


\section{Iron Age Celts: Previous Study}

\section{The "Celts" Problem}

In the early 19th century, we understood Celts as from Gaul. Thierry (1827) used first century BC Caesar and Strabo to locate Livy's Celts (see Collis 2003, fig. 20). This classicist understanding subsequently became confused with the inclusion of archaeological studies. By the 1860s-1870s, "Celtic" was used by archaeologists to mean pre-Roman. Our Iron Age type sites-the Hallstatt salt mine in Austria and La Tène ritual lake in Switzerland-were each labeled Celtic, with British La Tène art "Late Celtic" (Collis 1996, pp. 22-23; Kruta 1997, p. 27). The whole of the Iron Age had become Celtic. Meanwhile, a link was established between the archaeology of La Tène and neighboring North Italy (Mortillet 1871), apparently corroborating Polybius and Livy on early Celtic migrations to Italy. By the mid-1870s, an important debate began between medieval historian and philologist d'Arbois de Jubainville (1875) and archaeologist Bertrand (1876). After the "several names" problem identified first by Pezron (1703), d'Arbois de Jubainville conflated "Celts" and "Galatai," using linguistics to argue for Celts across Europe: a "Celtic empire" of south German origin. Bertrand instead saw social distinction between "Celts" and "Galatai," seeking instead to marry texts and material culture with applied dating to define smaller social units across space/time. The difference between the two scholars and their evidence was one of scale-large-scale linguistics versus small-scale archaeology. It was also one of method-generalist versus particularist—-the debate that remains today.

The political and social context of this expansion of "the Celts"-from Thierry's (1827) Gaul to d'Arbois de Jubainville's (1875) empire-is a backward projection of contemporary European imperialist attitudes (Trigger 1984, p. $110 \mathrm{ff}$.). In Britain, Pitt Rivers saw hillforts reflecting the perpetual hostility of tribal society, as he employed craniometry in his Cranborne Chase excavations to understand race (Lane Fox 1868). At Oxbridge, contemporaries of Darwin saw different types of hillfort as denoting "successive races of men" advancing in civilization-indigenous British supplanted by Caesar's Belgae, with invasion of Goidelic/Brythonic Celts explaining language change (Cardale Babington 1881; Rhŷs 1882). Some late 19th century Iron Age scholars chose generalizing method (history/linguistics) in support of evolutionary thinking, invasionism, and race science over burgeoning notions of cultural particularism (archaeology/anthropology) under Bertrand.

By the 1910s, however, influential Iron Age scholars in France and Britain were developing method toward archaeological cultures-Déchelette mapping burials to historical groups and Cunnington developing chronology from ceramics (Collis 2009b). Déchelette (1913) saw Celts “arriving” while Cunnington (1923) proposed instead long-term, small-scale incursions. Unfortunately, Déchelette continued to follow d'Arbois de Jubainville in accepting French La Tène art as "Celtic" and of Hallstatt origin (Collis 2003, p. 90). In early 20th century French scholarship, with Celts=La Tène, Celts spread from Gaul to 
Bohemia. Déchelette's acceptance of the Victorian Celtic labeling of European Iron Age archaeology, supported by geographically broad linguistics/material culture spreads and late 19th century imperialist thinking, was retained by the British School into the late 1950s. Despite the methodological progress of Cunnington and her demonstration of development from Bronze Age ceramics, British thinking reverted to historicism/invasionism following WWI, taken forward by Hawkes (Hawkes and Dunning 1931; Wheeler 1921), albeit critiqued by Cunnington (1932). Meanwhile, Childe's "cultures" (1929, pp. v-vi) continued to focus on large-scale synthesis, diffusionism, and notions of progress.

Celtic art scholars continued to apply this old method. Powell (1958) saw a "Hallstatt culture" across all of Europe, his La Tène "Celts" of the art style saw fourth/third century BC "expansion" via the historically attested migrations. While Powell was content to split culture temporally, he continued to lump it geographically, meaning that the Victorian idea of "empire" simply morphed into large-scale early-mid-20th century "cultures" on the basis of broad-brush similarities in material culture. Critically, the important work of Irish scholar Dinan (1911) was absent from Powell's bibliography, leading to a continued acceptance of historical Celts $=$ La Tène art style, which we now know to be incorrect. In the post-war publishing boom, Thames and Hudson books on Celts by Powell (1958) and medievalist Chadwick (1964), intended for a popular audience, saw La Tène art=Celtic cemented in the imagination of the British public. Meanwhile, Piggott (1967) began the project, continued by Collis, of resolving the scholastic histories. These broad 1950s-1960s ideas on "Celtic culture" in art history and medieval studies were very different, however, from contemporary archaeological thinking in British hillfort studies.

By the 1950s, a generation of British fieldworkers, particularly out of the London Institute, were moving against Hawkes' historicism, having recognized that the theory did not fit the ceramics (see Cunliffe 1991, pp. 13-15; Prtak 2019). More akin to Bertrand/Cunnington, this field was increasingly interested in defining "regional characteristics" from the archaeology, e.g., the enormously important work of Kenyon (1952). Hodson (1964) subsequently focused on the material differences between Britain and the Continent (e.g., round versus rectilinear houses). Two years later, an influential paper by Clark (1966) saw full and final rejection of invasionism in British archaeology. Younger scholars stressed continuity in their efforts to move against narratives of culture change as external. As a result, both Chadwick (1971, p. 38) and Powell $(1971,1976)$ began to consider late Hallstatt culture as "Celtic," having previously accepted culture change at 450 BC. In 1970s France, however, Kruta's (1976) popular paperback Les Celtes began at Herodotus and the sacking of Rome, a separate $450 \mathrm{BC}$ origin for the Celts (=La Tène) akin to Powell (1958). The following year, Duval (1977), restating Déchelette, labeled the well-known "watershed distribution" of late Hallstatt archaeology as "origin of the Celts." As a result, "Celts" remained La Tène, of late Hallstatt origin, into the late 20th century (e.g., James 1993; Kruta 1997; Pauli 1980). The thinking of d'Arbois de Jubainville remained. 


\section{Hillforts and Social Modeling}

Meanwhile, discovery of the high-status tombs of Vix (1953) and Hochdorf (1968, excavated 1978-1979) created interest in their related settlements (Joffroy 1954, 1960; Kimmig 1969). Kimmig established a link between small late Hallstatt/Early Iron Age hilltop enclosures and an apparent social hierarchy, as demonstrated by these associated "princely" burials. Meanwhile in Cambridge, Clarke's (1972) social model for Glastonbury saw Iron Age society divided by sex (see Pope 2011 for social context). Having reconstructed regional settlement and ceramics types for Britain in 1974, after Kenyon (1952), Cunliffe (1984, p. 561) understood that Iron Age social structure varied across space. However, 1980s' archaeology lacked the method to reconstruct "society" beyond analogy, something upon which later 20th century archaeology relied very heavily (Binford 1967; Clarke 1972; Hodder 1982). As such, German and British scholars constructed social evolutionary models of "Celtic society" (Cunliffe 1984; Eggert 1988; Fischer 1995; Frankenstein and Rowlands 1978). Ideas of "warrior societies" and territorial expansion were linked to trade-based interactions with the Mediterranean in core-periphery models (Brun 1994; Cunliffe 1988; Nash 1984, 1985; Pare 1991), with hilltop enclosures as central places (Brun 1988; Büchsenseschütz 1995; Cunliffe 1974, p. 305, 1984). This flowed into ideas of late Hallstatt kingship/royalty (Cunliffe 1983, fig. 94; Krausse 1999; Kristiansen 1998; Veit 2000) and on into urbanism and state formation, with the advent of second century BC oppida (Brun 1995; Collis 1995; Cunliffe and Rowley 1976). Ideas of aggregation as urbanism continue, with late Hallstatt Heuneburg now a "town" (Fernandez-Götz 2014a, b; see Moore 2017).

Thinking in these later 20th century archaeologies was evolutionary, diffusionist, and hierarchical, and an important retrospective on "Celtic society" is provided by Collis (2019). Thinking was also androcentric. High-status burials evidenced "Celtic" social hierarchies (princes, kings, cities, states): Celtic society was male dominated, with any "princely" graves of women explained away as ritualists or transvestites (e.g., Pauli 1972; Spindler 1983; see Arnold 1991). The sex of Vix was heavily debated. Apparently "only a fraction of the population was formally buried... members of the political, economic, and religious elite" (Brun 2018), an idea stemming perhaps from the social profile of late Hallstatt burials failing to adhere to a stratified, triangular society, as envisaged (e.g., Fernández-Götz and Ralston 2017). Ideas of Celtic society retained Celts as a monolithic entity, so that by the mid-1990s Celts were as widespread as ever. Arnold and Gibson (1995) saw Celts from Britain to Anatolia, and Green's substantial edited volume (1995) took Celts through the medieval period and into the modern era. Celts of the 1990s were as widespread as during the late 19th century.

In all this work, the central problem in Iron Age studies (Celts=La Tène) remained unresolved, despite both Piggott (1967) and Chadwick (1971) recognizing that, in the texts, the term dated to before 450 BC. Piggott (1983) avoided the issue, bringing out a second edition of Powell's (1958) book. Meanwhile in Italian philology, Prosdocimi (1984) recognized Celtic-Etruscan inscriptions in the Golasecca region, dating to 600-400 BC. This, alongside textual references to Celts at 500 BC, suggested that Celts=La Tène (i.e., Powell (1958)/Kruta (1976) must not be 
correct. After Duval (1977), some 1990s' scholars (e.g., Fischer 1995; James 1993) continued to use "early Celts" for the late Hallstatt period. Others followed Powell/ Kruta more closely, including French scholar Brun (1995) who considered "with certainty" that Celts=La Tène, from 400 BC onward, with the continued assertion (after d'Arbois de Jubainville, Piggott) that "Celts" and "Gauls" were terms used interchangeably in the early texts. Cunliffe (1997), too, continued to accept Celts=La Tène, pairing the La Tène archaeology of Rhineland/Champagne/Bohemia with Livy's Celts, and late Hallstatt as equivalent to Plato's "barbarians." Only Collis $(1994,1996,1997)$ began to state that Celts $\neq$ La Tène.

Nevertheless, the Oxford School brought 1960s', and ultimately Victorian, ideas on Celts into the early 21 st century. Using the "Celtic mixing pot" method, one could never study origins (due to a lack of chronological precision), the subregional nature of society, or ideas of ongoing, small-scale mobility, beyond notions of large-scale migrations/invasion. Oxford continued to accept historicism (d'Arbois de Jubainville, Déchelette, Powell) over archaeological method (Bertrand, Cunnington, Kenyon). In material culture studies, Nash Briggs (2003, 2007) discussed economic links and transmission of culture. Koch, a linguist, attempted "Celticization" and a retrogressive bid to salvage invasionism (Koch et al. 2007). Koch's (2009, 2011) premise that Tartessian might be considered an [early] Celtic language was heavily critiqued by philologists (see Sims-Williams 2016, footnote 47, 2020, p. 12). Similarly, the subsequent Celtic from the West hypothesis (Cunliffe and Koch 2012) was rapidly critiqued on its archaeological modeling, as culture-historical diffusionism (Karl 2012). Cunliffe did, however, make good the problematic 1990s' English/ French notion of Celts=La Tène, making clear our need to separate Celts and La Tène material culture (Cunliffe 2012, p. 17), as suggested by Collis since 1994. A major achievement has been to uncouple the link between Atlantic western "Celtic" linguistics and Iron Age archaeology alone, with a successful argument for deeper, prehistoric ancestry, as this interdisciplinary collaboration now begins to bear fruit (Cunliffe and Koch 2013, 2016, 2019; see Pope 2020).

\section{Settlements and Critical Method}

Contemporary with Hodder's post-processualism out of Cambridge, a turning point for Iron Age studies was Collis (1984), who rejected culture-historical "Celts" in favor of the increasingly archaeological study of the European Iron Age (Collis 1986, 1996; comment by Megaw and Megaw 1992, p. 254). In British Iron Age studies, reviews critical of Cunliffe's social model for Danebury (Collis 1985; Haselgrove 1986) set the tone for new thinking on the Iron Age, including radical theory from Bowden and McOmish (1987), Stopford's critically important (1987) work against historicist narrative, followed by Hill (1989), and feminist thinking out of the United States (Arnold 1991; Ehrenberg 1989). Even among the older generation, Pauli (1994) labeled much of the 1980s' social modeling "banal," while Collis (1994) critiqued warrior societies and nucleation=hierarchy even as he remained focused on notions of power. Meanwhile, Hill $(1995,1996)$ began to consider a different, egalitarian Iron Age, critiquing the settlement hierarchy=social hierarchy 
principle and offering alternative routes into the data; Crumley (1995a) called for polity-level research; and Arnold (1995a) focused on the nature of the Hallstatt-La Tène transition. In Celtic art studies, an important debate developed between Collis and the Megaws, primarily about La Tène art being mislabeled "Celtic" but, more importantly, on false and politically dangerous notions of European "Celtic" ethnicity. Collis' argument was that the spread of "Celtic art," or language, does not reveal shared "Celtic" ideology/ethnicity, not only because "Celtic art" is not actually Celtic but because (after Clarke 1968) the relationship between art, language, and ethnicity is complex and intersecting (Collis 1996, 1997; Karl 2004; Megaw and Megaw 1996; Sims-Williams 1998). A particular turning point was Collis' (1996) explicit rejection of a Celtic "culture," especially if linked to ethnicity. Another came in the publication of the 1991 Celts exhibition at the Palazzo Grassi, Venice, with its clear focus on material by region (Moscati et al. 1997).

Settlement archaeology of the 1990s brought methodological progress. A continued focus on hillforts (e.g., Hill 1996; Pauli 1994) provided only limited ready information on regional social structures and thus new understandings of "society." In northern Europe, however, a new school of archaeological method was developing, with a focus on houses, households, and the social organization of settlements (Gwilt and Haselgrove 1997; Hingley 1984; Samson 1990). This late 20th century work was a development of the regional traditions that have been recognized in settlement studies since the work of Fox (1953), Hodson (1964), and Cunliffe (1974). Scholars began to exchange abstract social modeling for regional-level household studies and a longue durée approach to larger archaeological datasets (e.g., Brück 1999; Fokkens 1998; Fontijn and Fokkens 2007; Gerritsen 2003; Hedeager 1992; Pope 2003, 2007; Webley 2008). Interest turned to Marx's "Germanic" mode of production and Evans-Pritchard's east African pastoralist/segmentary societies (Hill 1995; Hingley 1984), where households retain the means of production (cattle/arable) alongside communal rites over pasture/surplus (see Sastre 2011). This was very different from Kimmig's hierarchical "Celtic society" modeled on the hillforts and high-status burials of the "watershed area" farther east. As a result, the "Celtic expansion from core" model for Iron Age Europe was rejected by the mid2000s, with archaeologically distinct "culturally differentiated groups" recognized instead (Diepeveen-Jansen 2007; Kruta 2005, pp. 14; 29), more in line, finally, with Bertrand. As settlement archaeology focused on households, the scale of analysis around Celts also reduced. This involved detailing the historiography surrounding the conflation of modern and first millennium AD Celtic identities with the Iron Age archaeology, separating out Celtic studies into sister fields (archaeology, history, linguistics) in a bid to gain a developed academic understanding of each (Collis 1996, 2003, 2008; Cunliffe 2013, Cunliffe and Koch 2016; James 1999; Karl and Stifter 2007). On the question of origins of the Celts, however, the answer remained: "we do not know" (Collis 2003, p. 223).

Attempts to understand "Iron Age society" were improved by critiquing social hierarchy as a baseline state (Cripps 2007; Crumley 1995b; Hill 2006) and moving beyond analogy to contextual practice, with social models led more explicitly by the material evidence (see Pope 2007). In two important papers, Collis (2008, 2009a) called for an end to grand narrative around "the Celts" and instead new method-a 
sequencing of events-more akin to that of settlement archaeology, with a focus on chronology and regionality. Karl (2012) requested more scholarly, scientific practice, with notions of pan-European culture, expansion, and diffusionist spread no longer accepted (Pope 2015a). Arnold (2012) and Fernández-Götz (2014a, fig. 5, 2014b) instead considered temporality/biography. Hill (2011) began to consider British Iron Age societies as heterarchical/segmentary, with households linked to (15-20 km) kin-networks, gathering periodically as wider hillfort communities. That archaeologists understand the mechanisms of kinship and how households build into community is now of fundamental importance (see Brück 2021; Carsten 2003; Currás and Sastre 2019a, b; Sastre 2011; Strathern 2020). For this author, "segmentary societies" seems a good fit for the household-based pastoralist groups of the Early Iron Age Atlantic west (Scandinavia, Netherlands, Britain, Galicia, western France), which contrast with burial evidence for late Ha "lineages" farther east (Brun 2018, p. 19; Pope 2018, fig. 34.6). Different, too, is growth in communal/tribal identity in the "developed hillforts" of Britain after $400 \mathrm{BC}$, alongside lowland settlement agglomeration (Netherlands, Denmark, eastern England). To date, we have two models of Iron Age society (hierarchy and heterarchy), although we accept that there were many more-see Cunliffe (1984, p. 561) and Hill (2011) on multiple "messy" Iron Age societies, as cautiously identified here (Table 1; see also Currás and Sastre 2019a, b).

\section{Burials: Integrating Women}

One way in to a perceived multiplicity of prehistoric societies is to break down a further normative assumption that often partners hierarchy: social structures as necessarily universally male authored, an idea that was first critiqued by Chadwick (1971). Problematic thinking on the social role of prehistoric women in scholarship of the 1980s-2000s, particularly out of Cambridge, has been explored fully elsewhere (Arnold 1991; Ehrenberg 1989; Gilchrist 1999, pp. 17-18; Pope 2007, 2011; Pope and Ralston 2011, p. 376 ff.). Despite this, in our "different" Iron Age the focus continued to be on the primacy of men (Hill 2011). Even in this now more egalitarian society, women were apparently "not so equal," an assertion unsupported by archaeological evidence. Many working with the burial archaeology have now demonstrated that age rather than sex was the more important structuring principle for La Tène Gaul and Britain, with women equally likely to achieve high social status, apparently in their own right (e.g., Evans 2004; Giles 2012; Milcent 2003; Pope 2018; Pope and Ralston 2011, p. 409; Trémeaud 2019). Nevertheless, Collis and Karl (2018) use first century BC Roman texts to suggest that: "The political power of women in most of these societies was very limited." While accepting wealth in primary female burials as evidence for matrilineal inheritance, after Pauli (1972), with the possibility of women achieving high status in their own right grudgingly accepted for Vix, they speak of "exceptional circumstances" and reassure that high political status was typically for men. Collis and Karl argue uncritically that because Caesar saw women in a derogatory way, women across the Iron Age held no social power. They became keen to state that 


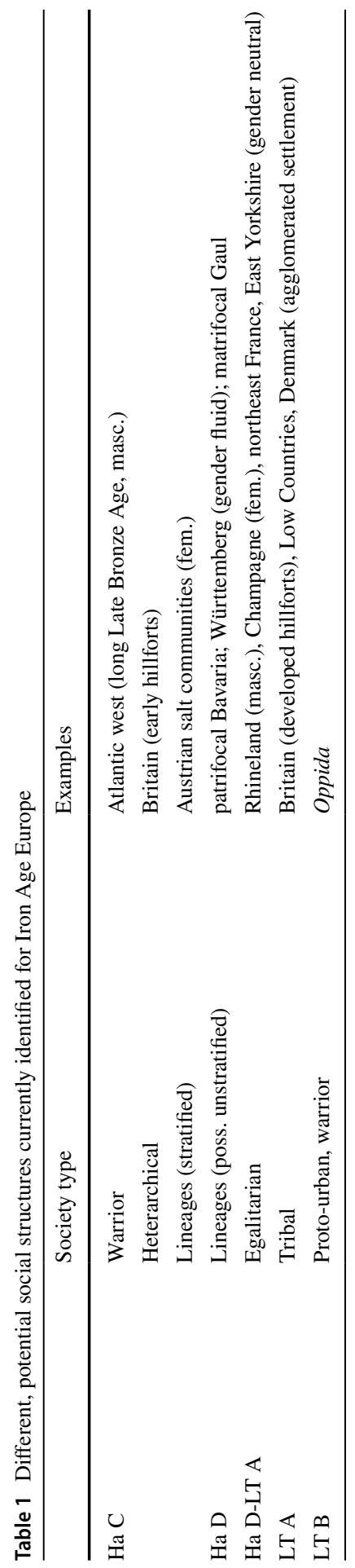


burial wealth need not imply power in these cases, preferring instead medieval, Roman, and modern ethnographic analogy over the Iron Age burial archaeology with its difficult-to-explain high-status women (see also Collis 2011, p. 233; Karl 2008). We find again the tired repetition of female wealth as only ever linked to marital status (i.e., Hinton 1986; James 1993), when indeed marriage may itself be an anachronism in some places, with gendered burial clusters in late Hallstatt Austria and Gaul and Caesar's reference to polyandry (women with several partners) in Britain. So it is that some scholars argue against the archaeology in favor of abstracted versions of Roman patriarchy and medieval feudalism as representing Iron Age Europe. While breaking down baseline notions of social hierarchy in Iron Age studies and advocating for radically "different" Iron Ages, the same scholars retain static and disappointingly conservative ideas on past women.

Instead, moving beyond binary (hierarchy vs. heterarchy) and unsupported a priori assumptions regarding social hierarchies, the attempt now is toward a form of cultural relativism/particularism in the vein of Boas. The idea is to gain information on multiple "societies" from a chronological sequencing of the regional burial archaeology. Certainly, Hill's ideas of a more egalitarian Iron Age find support in analysis of French and British La Tène cemeteries. Unfortunately, recent British work on "society" does not engage with a wealth of scholarship that works to reconstruct social forms from the mortuary evidence (Arnold 1991, 1995a, 2012; Burmeister 2000; Evans 2004; Giles 2012; Hodson 1990; Pope and Ralston 2011; Trémeaud 2019). Here, notions of what constitutes relative status and identity are explored, not via tired repetition of Caesar nor various forms of analogy and generalizing argument but in the steadfast development of new thinking and applied method to burial datasets. The regionality of these social forms is recognized in work at the level of cemetery/region (Pope and Ralston 2011, fig. 17.2; Trémeaud 2019, fig. 9), as a recent move into supraregional synthesis attempts the complex task of elucidating data-led social narratives (Pope 2018; Trémeaud 2018).

Mainstream British scholarship, nevertheless, continues to ignore comment, predominantly from French scholars, on the elevated status of women and the potential for matrilineal Early Iron Age society (e.g., Brun 2018; Fernández-Götz and Ralston 2017; Milcent 2003; Pauli 1972; Pope 2018; Pope and Ralston 2011; Roualet 1997; Trémeaud 2019). The terms matrifocal/patrifocal are preferred here rather than matrilineal/patrilineal. Matrifocal suggests female-authored social forms without alluding to the social mechanism (i.e., inheritance patterns, prescribed mobility) through which this might be achieved, although lineages are suggested by the Early Iron Age archaeology (see Pope 2018). Beyond France, Arnold (2012) suggests that patrilocal social forms are visible in the archaeology of contemporary southwestern Germany. Future, targeted, strontium isotope and aDNA studies might help identify any formal pattern (if indeed there were any) of men being brought into female lineages (matrilocality) or women brought into male lineages (patrilocality) among particular groups, leading to discussions on what this might then mean socially from the rest of the archaeological evidence. Reconstructing Iron Age societies (plural) must now be increasingly built up from regional archaeological data rather than via application of a notional, generic, top-down social model. 


\section{Recent Trends: Understanding Mobility}

This corpus of work that seeks to understand the nature of society from the burial data sits well alongside new thinking on networks and mobility, as discussed by Champion (1994, p. 149) and now aided by new science. This new potential enables us to discover patterns of movement in the archaeological data rather than only from historical texts (e.g., Polybius and Livy). The excellent, multistranded analysis of the Early Iron Age Magdalenenberg used osteology and isotopes to discuss diet, movement, and social structure, revealing individuals from Austria and the Alps/northern Italy (Oelze et al. 2012). Here and in Middle Iron Age Britain and Germany, isotope studies show that long-distance mobility was restricted to a few individuals (Green 2008; Jay and Montgomery 2020; McKinley et al. 2014; Scheeres et al. 2013) and was ungendered (Giles et al. 2020, pp. 58-59; Pope and Ralston 2011, p. 408). Meanwhile, archaeological evidence for potential migrations (e.g., Ha D1 Austria, Rhineland/Champagne across 550-450 BC, La Tène France) do reveal gendered signatures (Arnold 2012, p. 105; Pope 2018). Most recently, Fernández-Götz (2020) provides an excellent review of thinking on migration in recent scholarship, while Brunel et al. (2020) reveal aDNA studies as unable yet to reveal these small-scale events. aDNA studies seem to work best at the level of the cemetery (e.g., Kiesslich et al. 2005), such as important work by Antcil (2019) on contemporary burials from Hallstatt and Dürrnberg. Antcil's work revealed similar aDNA signatures in each cemetery, suggesting high levels of contact between the two-i.e., connected social networks rather than distinct, isolated groups. Similar homogeneity is now discussed by Brunel et al. (2020). Retaining a distinction between mobility (various scales and motivators for movement) as different from migration (a specific process) now seems sensible, as archaeological studies on mobility and isotopes/aDNA open up new thinking on identifying social/kinship networks archaeologically (Bickle 2019; Brück 2021; Frieman et al. 2019; Hakenbeck 2018). This is an exciting time for all who study past human populations.

\section{Methodology}

\section{Approaching the Archaeology}

The method I apply is primarily concerned with scale (see Champion 1994, pp. 145-147). As contextual archaeologists, our scale must be separate from that of Celtic language studies, which has a particular problem with the temporal/geographical resolution of the data. Archaeologists cannot define early first millennium $\mathrm{BC}$ Celts using the geographical distribution of Celtic place names, the language that survives in its most fully diffused state and widest geographic spread in the late Roman/early historic period. The scale of archaeological study has decreased steadily over time: from Victorian empires to Childe's prehistoric civilizations/cultures of Europe and the Middle East to Kenyon's regional characteristics, as expanded by the Scandi-Dutch school of the 1990s/2000s. With roots in the latter, I seek to move Iron Age Celts beyond 20th century grand narrative-the generalist, historical 
"mixing pot" where Celts (=Galatai=Gauls) are pan-European, across millennia. I seek to move, too, beyond the evolutionary narratives of chiefdom-tribe-state of the 1960s-1980s and analogy-reliant social modeling. This work is instead an attempt at cultural relativism and historical particularism; I seek to develop method toward identifying this archaeologically by comparing/contrasting increasingly detailed regional chronological information (Champion 1994, p. 150; Collis 1994, p. 33). As Bertrand (1876) wanted, this is ultimately an appreciation of cultural scale built from the archaeological record itself, revealing social forms through the archaeology. It is somewhat akin to settlement archaeology of the 1990s-2000s in documenting local/regional social characteristics, chronologically, with a focus on social change over time.

Methodologically, the first emphasis is on recognized regional archaeologies. I accept that, for Iron Age Europe, regional-level variation is most readily and consistently apparent in the burial archaeology-e.g., Ha D2/3 Bavaria has a different archaeological signature from the grave assemblages of (contemporary) neighboring Austria, which is different again from that to the west in Württemberg. Meanwhile, Württemberg's neighbor in northeast France has comparative material culture but different gender information, the latter more similar to Switzerland. The burial archaeology reveals "society" as a distinctly regional affair, at most (Clarke 1968). The dataset I use employs sequenced information from high-status Early-Middle Iron Age graves across seven key regions-primarily Austria, Bavaria, Württemberg, Rhineland, eastern central Gaul, Switzerland, and northern England-with data also from the Netherlands, Denmark, Ireland, Scotland, southern England, Spain, Portugal, Bohemia, Slovakia, Slovenia/Croatia and Hungary, comprising 374 entries (see Supplemental Tables 1-4).

From a literature of several thousand burials, and building on the data collation of Pare (1992), data were collected according to two principles: sex/gender information and relative high status (e.g., largest barrows, relative high-status goods, evidence for Mediterranean contact). This method has developed rapidly in the field since Hodson's (1990) work on the Hallstatt cemetery, which revealed status material culture and gender information, in particular, as two important markers for identifying social traditions in the European Iron Age (Clarke's 1968 social and sex subcultures). I consider these two areas as having the most potential to provide regional-level social information (i.e., interregional and Mediterranean connections, gendered social structures). Analyzing status variation within cemetery populations (e.g., Brun 2018) is also critical work but not the focus of this paper, due to the geographical scope currently necessary to approach the question of the Celts. Ideas around these twin sampling principles of relative status and gender information require some unpacking.

Archaeologists think critically about what grave goods represent, with potential meaning rooted in many things other than simplistic notions of social hierarchy or role, or even as necessarily related to individual identity/personhood in life (Arnold 2006; Brück 2004; Giles 2012). As such, discussing grave wealth in terms of an elite is problematic, especially as we do not yet understand the late Ha data sufficiently well, temporally or regionally, to necessarily demonstrate social stratification, beyond perhaps at Hallstatt, although critically workers there also had wealth. 
Meanwhile, Brun's (2018) argument for stratification in La Tène France is convincing. The social meaning of traditions involving grave wealth is increasingly ours to discover through contextual analysis, not something to assume. As such, I do not seek here to learn the meaning of status, instead I isolate status data as having the most potential to reveal variant regional social forms. What constitutes status on death is relative, varying in character between groups, and potentially representing different things to each; material culture perhaps may be a marker of authority in one region, but not another (see Collis 1994, p. 33; Collis and Karl 2018, pp. 5-7; Pope and Ralston 2011, p. 376). What we do know is that where ranking by grave wealth has been attempted, it is Iron Age women who hold more material wealth on death (e.g., Hinton 1986; Hodson 1990). In a much wider analysis of the north Alpine complex (721 graves), the two higher wealth classes are feminine; while masculine gender is quantitatively better represented, it is associated with the two poorer wealth classes (Trémeaud 2019). We also know that graves of both men and women display the material culture of political structures. Our objective here is to see how these matters varied across space, and over time, in our aim to develop a more nuanced understanding of Iron Age societies.

Developed thinking on the nature of gender is also critical. Despite early critical thinking in anthropology and social theory (de Beauvoir 1949; MacCormack and Strathern 1980; Mead 1935, 1950) and subsequently in archaeology (Conkey and Spector 1984; Gero 1983; Gero and Conkey 1991; Gilchrist 1999), mainstream studies have continued to struggle to understand gender beyond binary sex stereotypes. This extends also into method. Despite interpreting grave wealth with male bodies as power, we instead begin to question that relationship when female burials display wealth or weapons (e.g., Hinton 1986, pp. 364-365; see Arnold 1991; Trémeaud 2019). We might now label this the Birka problem, after the mental gymnastics that followed aDNA science demonstrating the Birka warrior as a woman (HedenstiernaJonson et al. 2017). The past is different and changing our interpretations of material culture associations on the basis of sex/gender alone tells us more about contemporary attitudes to women than it does about people in the past.

Early queer theory saw gender as a social structure tied to (binary) biological sex, imposed and performative (Butler 1990). Since then, gender has increasingly been understood more as a spectrum than binary (Richards et al. 2017). Currently, gender is seen in terms of identity/agency, with a biological element perhaps next to be resolved. For Butler (2020), this presents culturally as the "diverse and historically shifting meanings of gender," signatures that may then be glimpsed structurally in the burial archaeology, or they equally may be socially prohibited (see Arnold 2006; Trémeaud 2019, p. 278; Turek 2016; Walley 2019). As archaeologists, we must clearly distinguish between osteological sex and perceived genders built up from archaeological analysis (Table 2). Rather than talking about male and female burials, I prefer to refer to masculine/feminine assemblages, which allows for different and complex notions of past gender and helps extend potential identities beyond those determined by biological sex as we currently perceive it.

Iron Age studies in Austria and Germany were first to attempt acquisition of gender information, experimenting with assemblage seriation in the absence of biological data. Hodson (1990) found status ungendered; Arnold (1991) identified 
Table 2 Sex and gender signifiers used in the dataset, including most-securely gendered artifacts in Iron Age Austria and Germany (after Arnold 1991, 2012; Burmeister 2000; Hodson 1990)

\begin{tabular}{|c|c|}
\hline $\mathrm{M}, \mathrm{F}$ & Sexed bodies \\
\hline $\mathrm{m}$. & $\begin{array}{l}\text { Typically masculine assemblages (i.e., razor, single arm ring, bicep } \\
\text { ring, iron belt plate, iron needle) }\end{array}$ \\
\hline f. & $\begin{array}{l}\text { Typically feminine assemblages (i.e., bronze neck ring, arm-ring pair, } \\
\text { anklets, amber, earrings, hair ornament, bronze belthooks, bronze } \\
\text { needles }\end{array}$ \\
\hline $\mathrm{m} . / \mathrm{f}$. & Where non-binary gender is indicated in the assemblage, uncertainty \\
\hline
\end{tabular}

feminine assemblages with spears; while Burmeister (2000) found a 10-15\% crossover between masculine and feminine assemblages. Evans (2004) found that even when gender was most defined (La Tène A France), still $40 \%$ of burials were gender neutral; Trémeaud (2019) gives a 20\% figure. Using osteological analysis, Pope and Ralston (2011, fig. 17.8) found some objects more gendered (martial masculine, mirrors feminine) than others (chariots, craftworking, jewelry), as we also recognized that gender markers vary across time and space (Arnold 2012, p. 95). We are now identifying different genders, both for women (Bickle 2019; Pope and Ralston 2011, p. 397) and men (Giles 2012; Pope 2018). For example, while Iron Age highstatus masculinity often displays a concern with martial metaphors, in patrifocal Ha D1 Bavaria some elder high-status men instead displayed toilet equipment. In Middle Iron Age Britain, martial ideologies seem open to elder women, but martial practice is linked to younger men-Iron Age gender was more concerned with age than sex. It is understood that analysis beyond the scale of the grave, as necessary here, obscures detail. Grave assemblages require close contextual study to determine whether goods were worn by the deceased or placed by mourners (e.g., Arnold 2012; Giles 2012). At the Magdalenenburg, for example, bodies with both masculine and feminine markers turned out, on inclusion of the osteology, to be children/ adolescents, perhaps with goods from each parent (Pope 2018, pp. 8-9). As such, method/analysis at both scales must develop in tandem.

Data collection had to span the period 800-250 BC to resolve what constitutes "Celts" by explicitly covering origins, the late Hallstatt period, and the Hallstatt-La Tène transition. Understanding the latter, which moves from wealthy Ha D lineages to egalitarian La Tène groups, with warrior ideologies at the Ha D periphery, is of particular importance in resolving "Celts" due to the inherited Celts=La Tène problem. Absolute dating remains limited; however, period categories (Ha D1-LT A) are each approximately of two generations (Table 3), with recent French scholarship putting more of what was once cautiously Ha D2/3 into Ha D2 (540-510 BC), i.e., the Vix generation. Data collection, rather than selection, was reliant on accessibility, so it is not exhaustive, and omissions must be expected. Much work remains, both in refining our chronologies and in continually improving our thinking/method around what burial status and gender constitute.

Archaeological data for $800-250 \mathrm{BC}$, with markers for status and sex/gender information, were sequenced chronologically (see Supplemental Tables 1-4). 
Table 3 Chronology used in the text

\begin{tabular}{ll}
\hline Period & Dates \\
\hline Ha C & $800-615$ BC \\
Ha D1 & $615-550$ BC \\
Ha D2 & $550-500$ BC \\
Ha D3 & $500-450$ BC \\
LT A & $450-400$ BC \\
LT B & $400-250$ BC \\
\hline
\end{tabular}

Then, approaching the texts as a chronologist/contextual archaeologist, I similarly sequenced information from 31 contemporary textual sources (Table 4), working to accept the usual caveats regarding partial survival, bias, translation. The objective was to add textual sources into the contemporary archaeological framework, combining historical and archaeological evidence and allowing each to help structure the other. Archaeology and texts were then combined in writing a chronological social narrative, in a bid to help Celts become contextual. This method builds on 1980s' thinking (Hodder 1986; Wylie 1985) that greater context enables a relatively better indication of meaning. While not resorting to the acceptance of objective truths, we can realize the potential for relatively "better" narratives of the past by increasingly grounding them in contextual archaeological data instead of analogy. The method is akin to archaeological principles of stratigraphy in applied single-context field method, the breakdown of time into contexts (events) and sequencing them to build narrative (see also Pope et al. 2020). Beyond historicist romanticism and analogy, this applied method attempts to bring together text and archaeology (humanities and science) in increasingly contextual approaches to the past.

\section{Archaeologists and Historical Sources}

Before turning to our new chronological narrative, I briefly consider the problematic way that archaeologists have previously employed historical texts. Archaeologists trained in the 1960s and 1970s continued to generalize. Instead of working to understand texts historically/contextually (i.e., what fifth/fourth century BC Greeks thought of Celts versus what first century BC/AD Romans thought of Celts), references to Keltoi, Celtae, Galatai, Galatae, and Galli were all simply conflated. This was the generalizing method of d'Arbois de Jubainville (1875). The core of the problem can be traced back to Piggott (1967), who believed the ancient authors were muddled, as repeated most recently by Cunliffe (2019a, p. 1) who suggests "Celt" as a general term, used "rather loosely" by classical authors for the people of central and western Europe. However, this notion of Celt as a general term is an artifact of archaeologists melding together of early and late texts. While Piggott was right that the Romans were muddled-Diodorus Siculus even left us a cautionary note on conflation by Roman authors (5.32.1), the Greeks were markedly less so. Rather than following Piggott (1967), we would have learned more on the early texts from Chadwick (Dillon and Chadwick 1967). Unfortunately, Chadwick's method on 


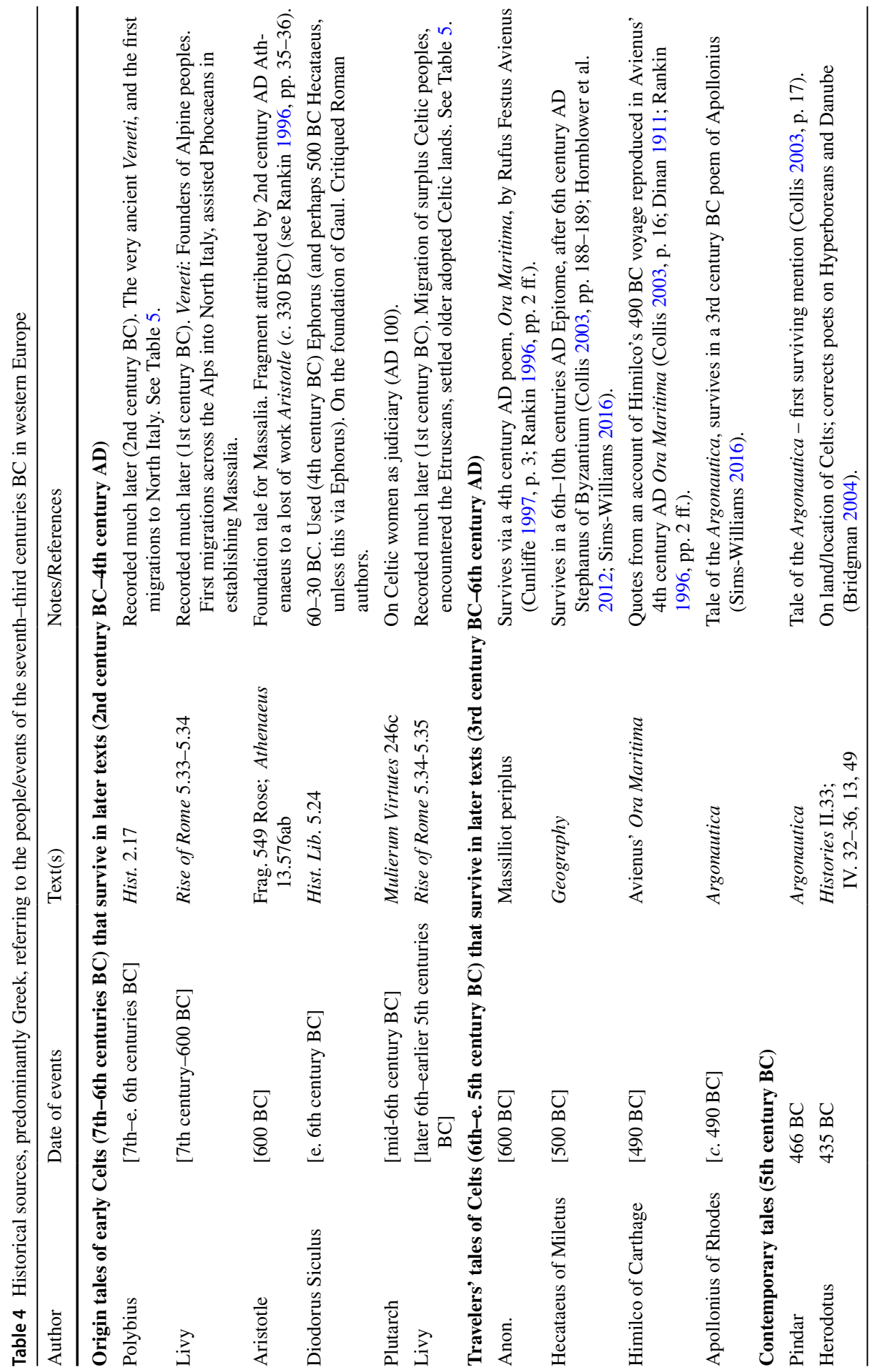




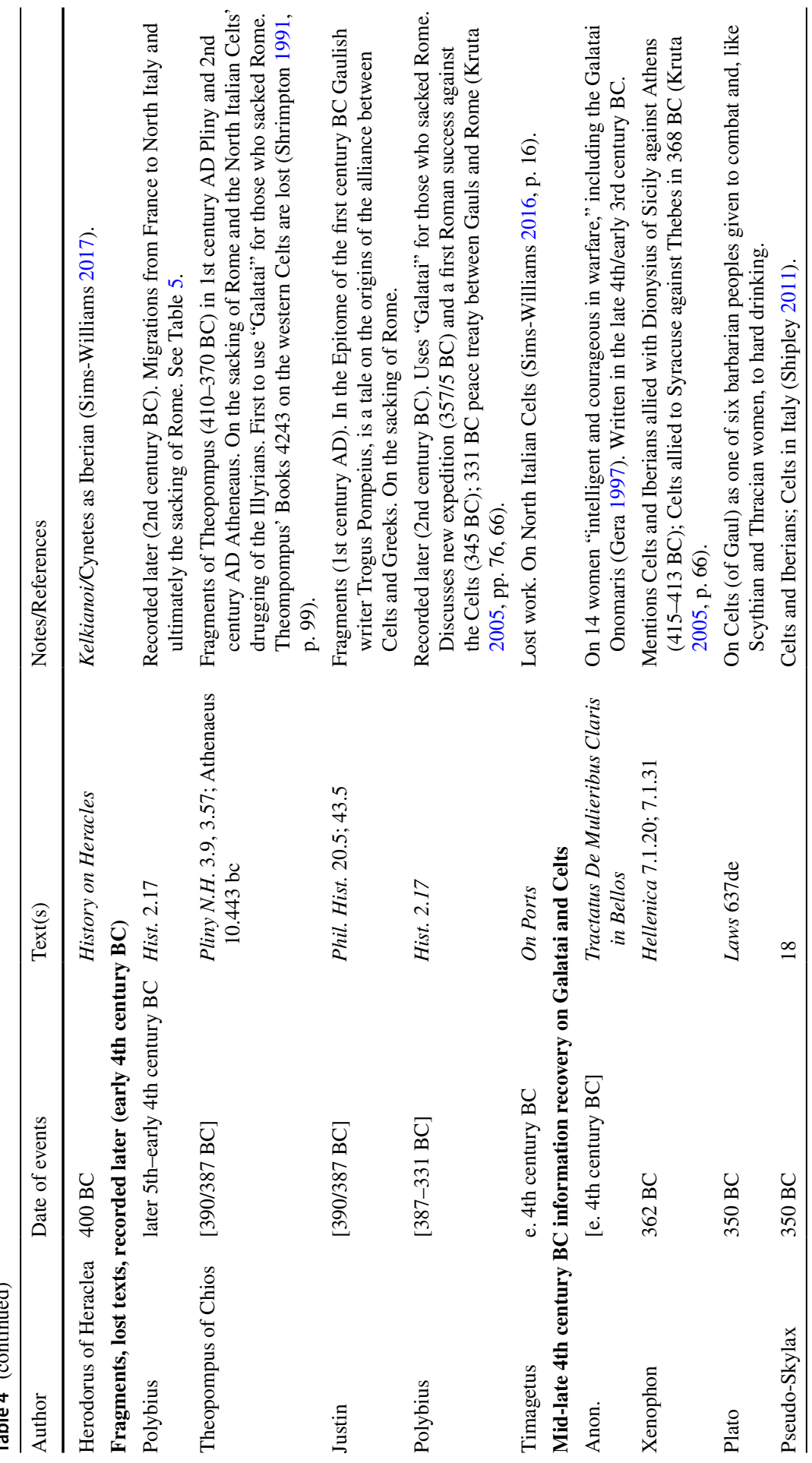




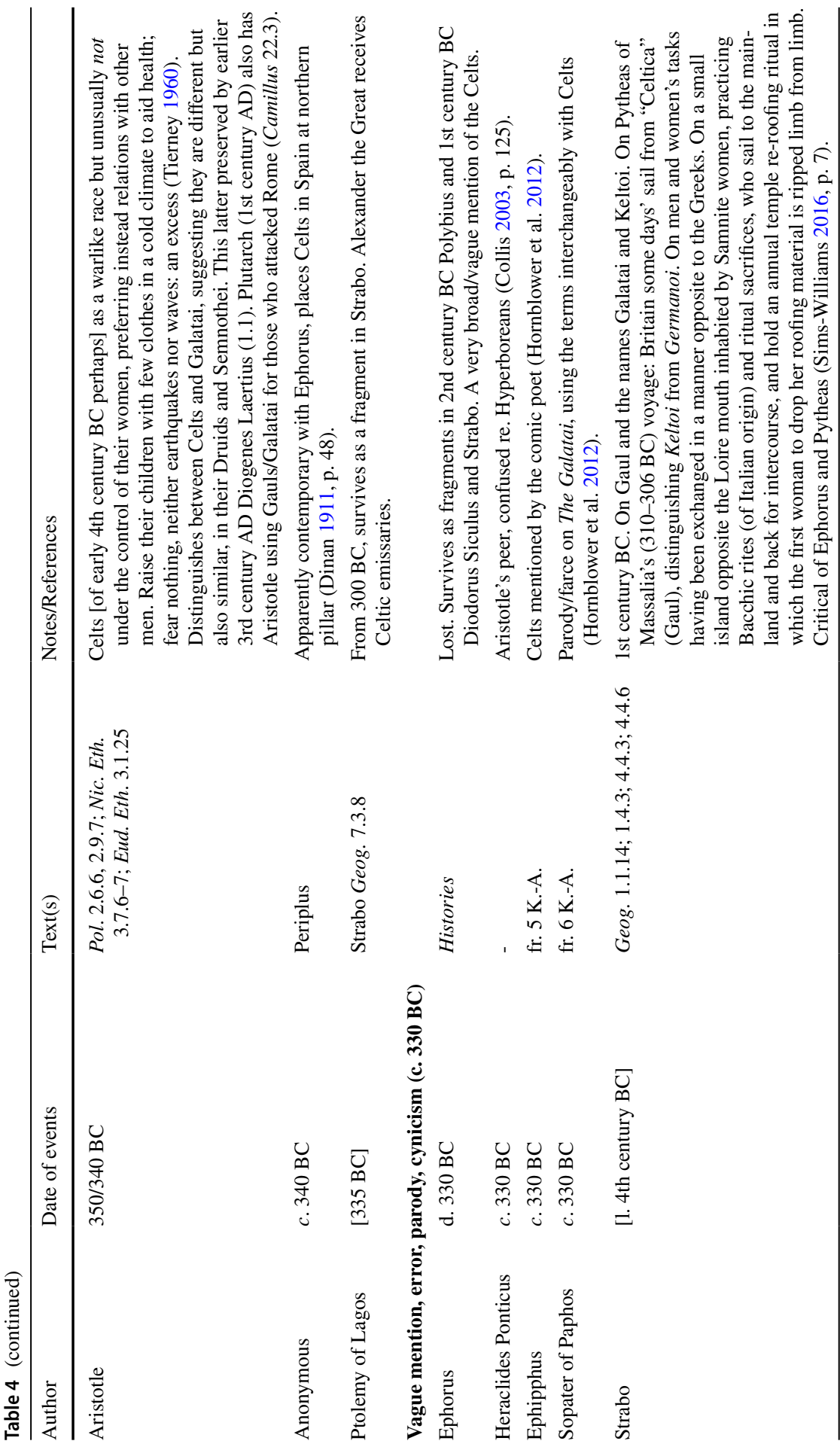




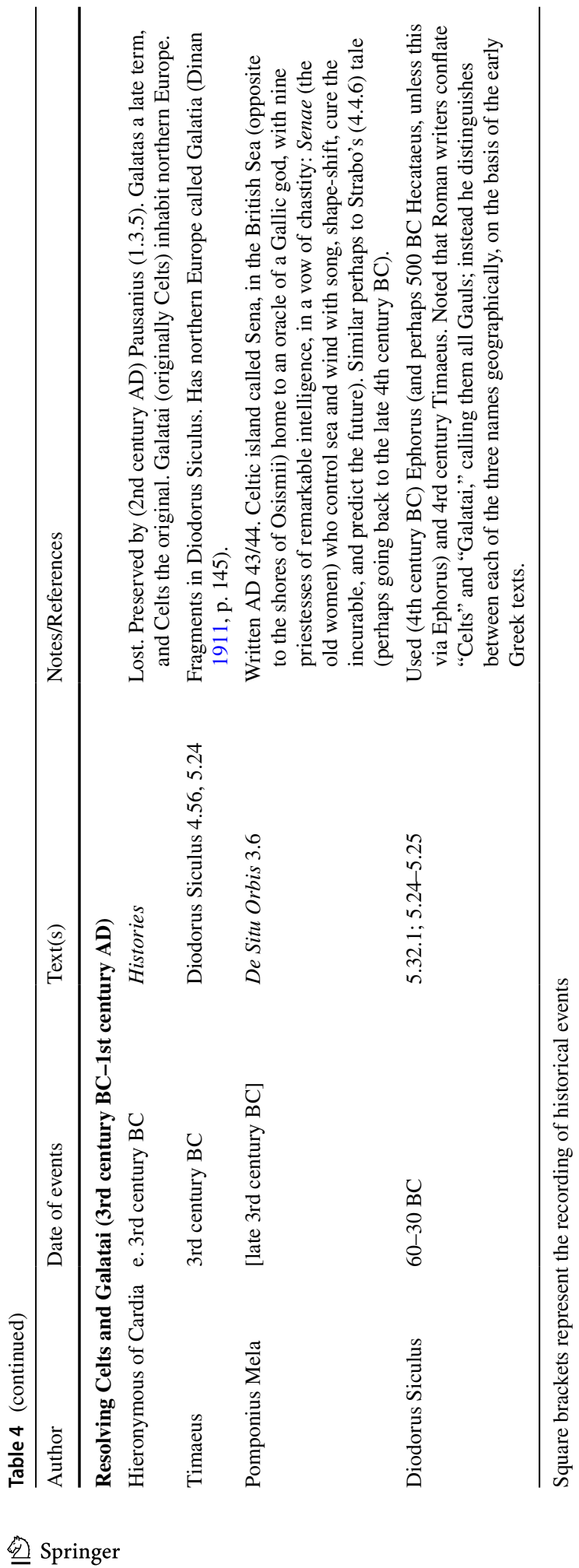


the early texts was not carried forward by late 20th century archaeologists in Cambridge, leaving our field poorer for it (see Pope 2011 for context). The result was that late 20th century archaeologists continued to see Celts spread across Europe, as in Victorian times (e.g., Brun 1995, p. 13; Cunliffe 1997, fig. 55; Megaw and Megaw 1989, fig. 2); only Collis was working toward separating out the textual evidence and beginning to think critically about its scope (1996, 2003, chapters 1, 6).

For archaeologists trained in the 1980s and 1990s, this earlier approach to the texts also revealed a lack of understanding of the importance of context (i.e., a lack of learning in post-processual archaeology). It revealed, too, a lack of understanding of the historical development of ideas in texts across time (i.e., a lack of learning from younger classicist colleagues) as well as of notions of cultural scale since Childe (i.e., a lack of learning from colleagues in anthropology). A generalizing approach to the texts was again validated by static "fossil maps" of linguistics data (e.g., Cunliffe 2012, fig. 1.1) that are devoid of temporal depth. As such, the pan-European notion of "Celts" cannot be blamed on the historical texts but on our own poor method (Karl 2012). Instead of treating the textual evidence contextually, like Chadwick, we now find that only some authors (usually Roman) used "Celt" as a general term, while early writers (Greek) were, in fact, relatively geographically specific.

A further problem was an archaeological focus on Caesar (e.g., Collis 1996). However, by Caesar's time we were several centuries on from understanding the origin of Celts, a term/identity already over half a millennium old. Our mid-late 20th century continuation of a generalizing notion of culture led us easily to ideas that a monolithic Celtic identity lasted into the early medieval period, when in fact we might now argue that Iron Age Celts had already begun morphing into new social identities at least as early as $450 \mathrm{BC}$. That said, the potential cultural continuity/ adoption of Celts as a subsequent identity-in North Italy, central Europe, and the Atlantic west-becomes an interesting topic for critical study in its own right. Different again, of course, is the Roman understanding of those identities and their histories. A further contextual textual assessment, in the nature of that undertaken here, is now required for the period after $300 \mathrm{BC}$.

Linked to the above is the assumption by archaeologists that Roman knowledge was as valid as Greek regarding Celts, rather than seeking to treat both the texts and the notion of identity temporally and working to unfold classical knowledge across time. We have instead been subjected to a circular argument: If we begin from the principle that everyone across Europe is a Celt, then we can throw all texts into the Celtic mixing pot and pull out confirmation that everyone across Europe is a Celt. The result is that we began, as a result of our own generalizing method, to develop a mistrust of the sources when they did not reflect back our own generalist understanding, a distrust that has moved beyond healthy critical engagement (e.g., Freeman 2001; or Collis 2003, p. 126 and Sims-Williams 2016, p. 17 on Herodotus), purely because the texts have been continuously, repeatedly taken out of historical context. We have seen progress in recent years on understanding historical texts as containing (political) bias and as relative in a cultural sense; every undergraduate can now recite this by rote. What we have not understood is that texts are also historically/temporally contingent. Texts are a manifestation of knowledge at a specific 
point in time; they are not an absolute. As with any other archaeology, trends in knowledge shift across time/space and do not follow the path of social evolutionary thinking. Caesar's first century BC understanding of Celts is very different from that of fourth century BC Plato.

A major problem, made worse by our constant bid to generalize, lies in acceptance of a later third century BC misreading of Herodotus' "beyond." In an era of confusion/parody in the classical texts (330 BC, see Table 4), the historian Ephorus considers Spain Celtic. This is heavily critiqued by first century BC Strabo: "Ephorus extends the boundaries of Keltica too far, including within it most of what we now name Iberia, as far as Gades" (Geog. 4.4.6). Arguably Strabo, who is also critical of Pytheas, may have too literal a reading of Ephorus' essentially schematic geographic trope (Sims-Williams 2016, p. 7). The degree of confusion caused by Ephorus' trope in subsequent scholarship, however, lends support to Strabo's slight pedantry. A further misreading of Herodotus by third century BC librarian, Eratosthenes, as Celts in Spain with the exception of Cadiz, only enhanced the scholastic problem (Kruta 2005, p. 14). In its fifth century BC seafaring context, Herodotus' Celts "beyond Cadiz" most likely references a coastal outpost, in the vein of Narbo, on the coast beyond Cadiz, supported by the fact that he differentiates between Keltoi and the more western Cynetes, the latter considered by near-contemporary Herodorus to be Iberian. Beyond this group of Celts beyond Cadiz, Spain-as-originallyCeltic is a misreading (ancient and modern) of Herodotus. The idea relies on Celtic place names, largely of the Roman period and late third century BC at their earliest (cf. Collis, 2003, pp. 130-131, 175-179; Cunliffe 1997, p. 137; Sims-Williams 2016; 2020, pp. 11-12). Beyond Herodotus' group in the southwest, most of Iberia then may not be considered "Celtic" until relatively late, i.e., late third century BC (the time of Eratosthenes, see comment by Dinan 1911, p. 145), as we begin to see Celtic language and La Tène material culture farther east. The dating of Celtiberian archaeology is critical here.

With these issues resolved, the texts can become another strand of archaeology. Classical texts become most useful in helping us understand the past when they are contextualized, something best achieved by archaeologists collaborating with classicists. Table 4 provides a synthesis of historical references to the Celts of the late Hallstatt and Hallstatt-La Tène transition period. This updates Dinan (1911) and Collis (2003) and will hopefully serve as a useful resource for future scholars. The texts are ordered chronologically, regarding the date of events recounted (given in square brackets when historical). If existing as later fragments, this is noted to aid contextualization.

This sequencing of the classical texts has revealed several distinct phases of historical activity. Apparently oral histories of the late seventh-early fifth centuries $\mathrm{BC}$ were written down in later texts, with the first contemporary accounts recorded in the mid-late fifth century BC. The early fourth century BC is a period of lost accounts (e.g., Theopompus' book on the western Celts), and it is interesting to consider that this may be a result of Rome desiring to rewrite its origins. After this there is a period of information recovery (mid-late fourth century BC) followed by an episode of vagueness/error/parody (330 BC). The third century BC is then a period of subsequent clarifications. Texts, like archaeology, are contextual. 
Historical texts are subject to temporal rhythms, and our reading of them can only benefit from the adoption of increasingly contextual archaeological method, toward a "genealogy" almost of classical thinking. Iron Age archaeologists must seek greater integration of classicists and ancient historians in our bid to further understand the social context of the texts, as we build them together with the archaeological evidence. In our bid to learn more about the origins of Celts, their society (plural), and social change, the combined historical and archaeological evidence is discussed below, chronologically, in three parts: Encountering the Celts (seventh-sixth centuries BC), power politics and the decline of Hallstatt/the Celts (550-450 BC), and making sense of a new era (450-350 BC).

\section{Encountering the Celts (Seventh-Sixth Centuries BC)}

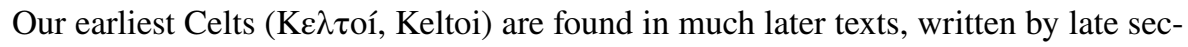
ond-first century BC historians, Polybius (Greek) and Livy (Roman). Here, the very ancient Veneti, Italic-Celts on the Adriatic coast, founders of the Alpine peoples, had at least seventh century BC origins, from Gaul (Table 5). In the archaeology of that time, final seventh century BC Celtic-Etruscan inscriptions farther west, in Golasecca, provide evidence for cultural integration of Celtic speakers in North Italy (Collis 2003, p. 191; Kruta 2005, p. 30). Celts, from Gaul, were perhaps settled then in two areas of North Italy by the seventh century BC. A well-established relationship between Etruscans and Celts was certainly reported by second century BC Polybius: "Their chief intercourse was with the Celts, because they occupied the adjoining districts" (Hist. 2.17). This relationship is attested archaeologically by Etruscan drinking vessels in high-status graves (Austria, Germany, France) typically between 700 and $400 \mathrm{BC}$ (continuing to $350 \mathrm{BC}$ at Waldalgesheim and $300 \mathrm{BC}$ in the Paris basin). For late second-first century BC classical writers, the first Celts were from Early Iron Age Gaul, small groups of whom had settled in North Italy to become friendly with the Etruscans.

Celtic language studies now consider Celtic to have developed originally in Bronze Age France (Sims-Williams 2020, p. 13). Similarly, following initial heavy critique, Koch's (2019) "Tartessian-Celtic" is now thought to be pre-700 BC, an Early Iron Age predecessor to La Tène Celtic of Bronze Age and deeper roots (Cunliffe and Koch 2019), and as such pre-dating our first classical references to Celts. Our earliest recognized Early Celtic languages (Venetic, Lepontic) are currently dated to $600 \mathrm{BC}$ (Koch 2019, p. 25), which my reworking of the classical evidence might now push slightly earlier. It seems possible that the fragments of an early Celtic language identified by Koch (2019) in Tartessian might stem from Sims-Williams' (2020) early Celtic language in Gaul, something perhaps confirmed by Herodotus' group of Celts beyond Cadiz. Celtic language proper became more widespread only in the La Tène period, with a late third century BC date at earliest for Spain and perhaps also Britain (Sims-Williams 2016, 2020, p. 13). A third century BC date is also given for Galatia in the east, converging now with the archaeology. The linguistics then appear to be resolving. 


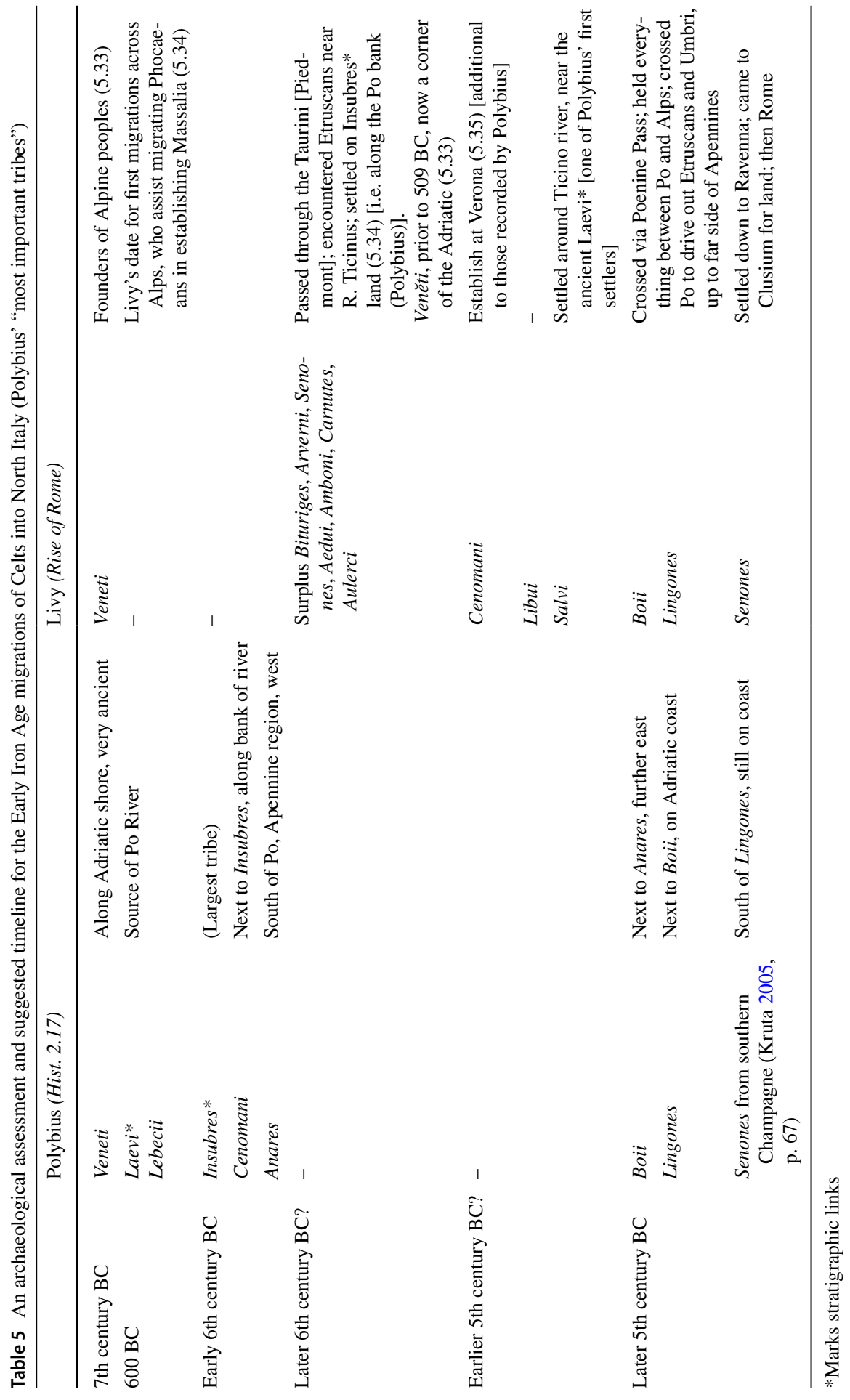


A new continuity of Late Bronze Age burial traditions is now recognized in the archaeology (Verger and Pernet 2013), meaning that these seventh century BC Celts in Gaul did not arrive (see Cunnington 1923; Chadwick 1971), now confirmed by the aDNA evidence (Brunel et al. 2020). Analysis by Trémeaud (2019) reveals a Middle Bronze Age rise in female status, followed by a period of well-documented Late Bronze Age masculine display. These social traditions continued into the earliest Iron Age in the Atlantic west, with iron swords the notable artifact between 800 and 625 BC (Brun 2018, p. 6), contemporary with lowland cattle-raising settlements in eastern Scotland that lack formal burial rites (Pope 2015b, 2018). Social signatures, however, were different farther east. Late Bronze Age Poland was instead more feminine/neutral, with wealthy women noted east to Slovenia and the Balkans, female warriors among the Scythians, and extraordinary female wealth among early Etruscan women, e.g., Regolini-Galassi (Cerveteri) and Barberini (Preneste) (Brun 2018; Cunliffe 2019b; Trémeaud 2019). In terms of location, status Ha C burials surrounded the Alps, and the settlement pattern reveals a focus on the upper valleys of the main European river systems (Fig. 1). This was at a time when the Hallstatt salt trade was at its seventh century BC height, revealing connections east to Italy, Slovenia, and Scythia, with feminine graves typically the richer (Supplemental Table 1; Hodson 1990; Pope 2018; Trémeaud 2019). Contemporary Germany/France, however, looked west, continuing patrifocal Late Bronze Age traditions, although some high-status female graves have now been found in France, prior to female status exploding after 600 BC (Trémeaud 2019; Supplemental Table 1). At 615 BC, an important social transition took place in western Europe, from $\mathrm{Ha} \mathrm{C}$ continuity of patrifocal Late Bronze Age mortuary traditions to an increasingly matrifocal Early Iron Age proper, in line with social norms farther east, out of the salt trade (Fig. 2).

A 600 BC foundation tale for Massalia (Marseilles) - recorded first by Aristotle (fourth century BC) and subsequently by Athenaeus (second century AD)-relates that, in the time of Tarquin (616-579 BC), a Gaulish leader's daughter, Petta, chose a Phocaean as her husband, and together they founded Massalia (Athen. 13.576a, b; Rankin 1996, pp. 35-36). Justin, in the Epitome of first century BC Trogus Pompeius of Gaul, tells a further tale on the origins of the alliance between Celts and Greeks (Phil. Hist. 43.5). In the archaeology, this Celtic-Greek friendship is referenced by Greek items in high-status graves in France typically between 540 and 450 $\mathrm{BC}$, and continuing to $350 \mathrm{BC}$ at Bourges. Meanwhile, second century BC Polybius describes the wandering open settlements of the Celts in Gaul, their concern for combat, cattle, and gold, with the Laevi and Lebecii moving first to the Po source near the Etruscans.

First century BC Livy has 600/590 BC as the first migration of Celts across the Alps, again in the form of an origin tale: two high-born brothers, Segovesus and Bellovesus, set out east with surplus population, one north to the Danube source, one south to the Po source. The archaeology does reveal the Danube source as a clear Ha D1 settlement focus (Fig. 3). The Celts, finding themselves in the same position as the migrating Phocaeans, helped the latter establish Massalia. Collis (2003, pp. 21-22, 121) suggests an error by Livy; however, Collis' reading conflates separate historical events. Despite Livy knowing that migrations began at 600 BC, he seems to detail those of the fifth century BC (see also Collis 2003, p. 170). 


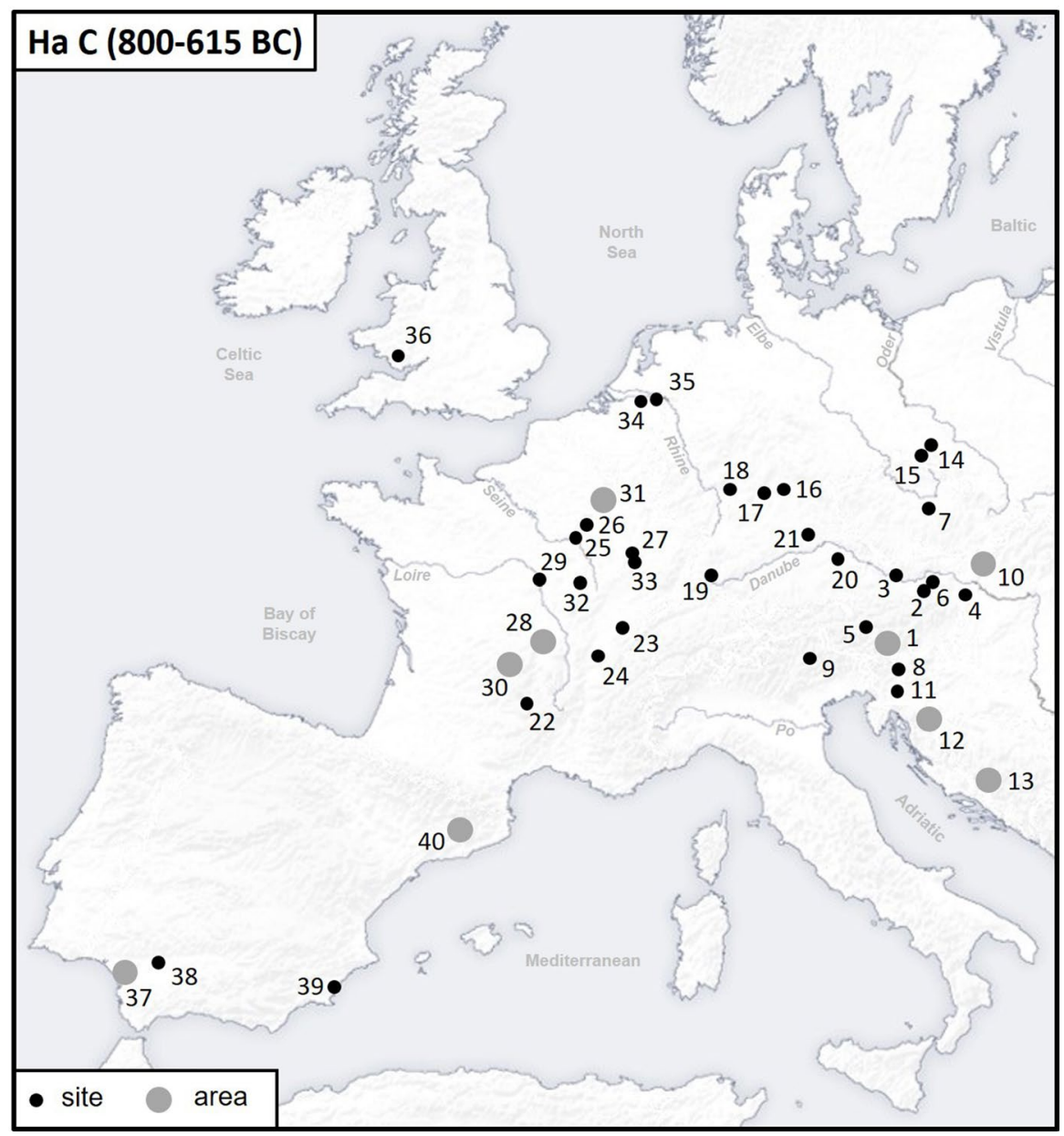

Fig. 1 Map of Ha C sites mentioned in the text (800-615 BC). Austria: 1 eastern Alps, 2 Statzendorf, 3 Mitterkirchen, 4 Zagersdorf, 5 Hallstatt, 6 Grafenwörth, 7 Inzersdorf an der Traisen, 8 Strettweg, 9 Ampass-Demfeld, 10 eastern Austria/Slovakia. Slovenia: 11 Stična. 12 Croatia. 13 Balkans. Czechia: 14 Platênice, 15 Hradenín. Germany: 16 Großeibstadt, 17 Donauwörth, 18 Frankfurter Stadtwald, 19 Magdalenenberg, 20 Pilsting-Oberndorf, 21 Schirndorf. France: 22 Séverac-le-Château, 23 Grand Communal (Doubs), 24 Chemilla, 25 Périgny-la-Rose, 26 Crancey, 27 Haroué, 28 northern massif central, 29 Berry, 30 Auvergne, 31 Champagne, 32 Magny-Lambert, 33 Diarville. Netherlands: 34 Oss, 35 Wijchen. Britain: 36 Llyn Fawr. Spain: 37 Tartessos, 38 Setefilla, 39 Cabeza Lucero, 40 northeastern Spain

Applying the principle of archaeological stratigraphy to the texts (Table 4), we find Livy's travelers, rather than being first to cross the Alps, occupy land already settled by the Insubres of Polybius' account, positioning the Greek account as earlier sixth century BC and Livy's as slightly later. In mapping the area of the groups mentioned by Polybius and Livy, using the geography of Strabo and Caesar-as undertaken by Thierry/Bertrand and Collis (Collis 2003, figs. 20 and 55)—we find their Celts in central Gaul (Fig. 4). Using second/first century BC oral histories and locations 


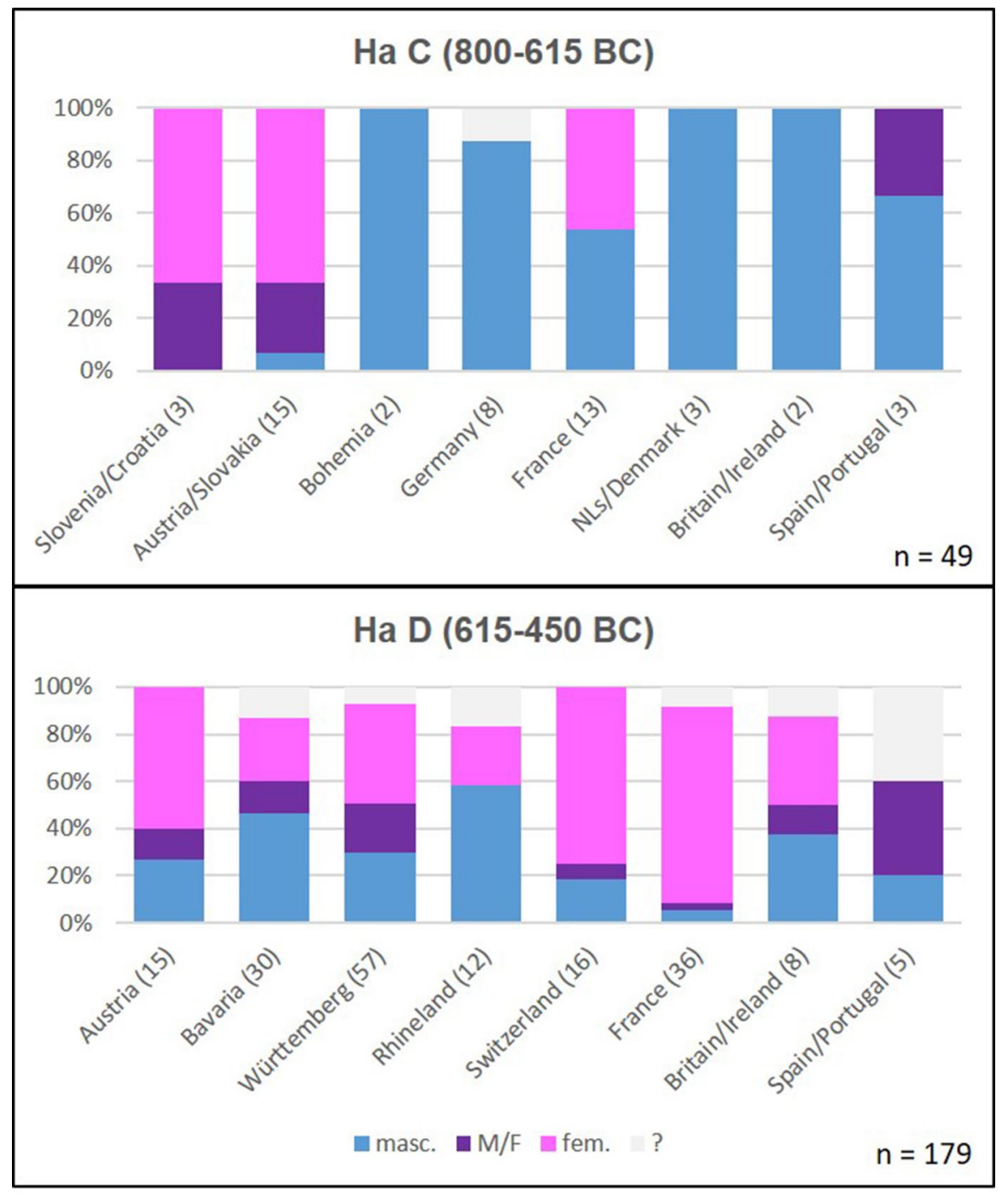

Fig. 2 The Ha C-D transition $(615 \mathrm{BC})$ as seen in the changing status of burial assemblages $(\mathrm{n}=228)$

to map groups reported four to five centuries earlier, however, is problematic, and it is assumed that the geographical area of the Early Iron Age groups was somewhat smaller. Also, Early Iron Age groups were valley based and did not span whole areas. As such, Fig. 4 remains an approximate reconstruction, based on later textual information. It is worth recognizing, too, that Hecataeus' recording Celts in southern central Gaul is not an indication of where Celts originated, it is simply where Greeks began to encounter them.

Classical tales, then, position Celts of $600 \mathrm{BC}$ as those of central Gaul, who, through population growth, sought land at the newly popular Danube source (i.e., 


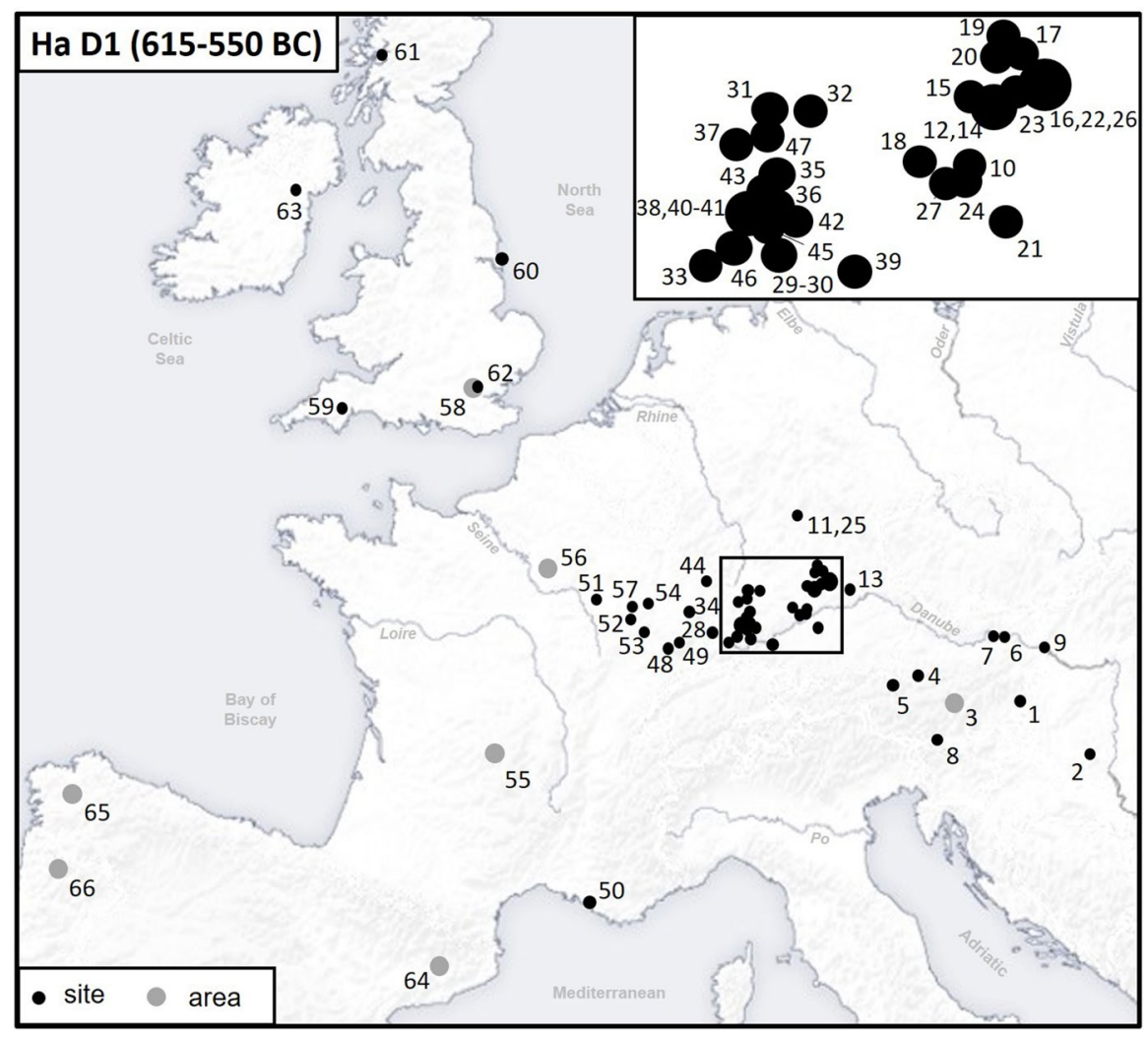

Fig. 3 Map of Ha D1 sites mentioned in the text (615-550 BC). Eastern Slovakia and Hungary: 1 Sopron, 2 Pécs, 3 eastern Alps. Austria: 4 Hallstatt, 5 Bischofshofen-Pestfriedhof, 6 Langenlebarn, 7 Gemeinlebarn, 8 Frög, 9 Mia á Saint-Georges-les-Baillargeaux. Bavaria: 10 Ausber-Kriegshaber, 11 Bad Königshofen-Merkershausen, 12 Beilngries, 13 Beratzhausen, 14 Dietfurt, 15 Hilpoltstein-Weinsfeld, 16 Hohenfels, 17 Illschwang-Gehrsricht, 18 Leipheim, 19 Neukirchen-Gaisheim, 20 Pilsach-Niederhofen, 21 Pöcking-Aschering, 22 Schmidmühlen-Markhof, 23 Velburg-Lengenfeld, 24 Wehringen. Bavaria: 25 Großeibstadt, 26 Lupburg-Gottesberg, 27 Waltenhausen. Württemberg: 28 Magdalenenberg, 29-30 Heuneburg environs (Bettelbühl, Hohmichele), 31 Gerlingen, 32 Heidenheim, 33 Neuhausen ob Eck, 34 Kappel-Grafenhausen, 35 Sankt Johann, 36 Hohenstein-Oberstetten, 37 Sulz am Neckar, 38 MeßstettenHossingen, 39 Tannheim, 40 Albstadt-Ebingen, 41 Bitz, 42 Emerkingen, 43 Engstingen-Großengstingen, 44 Hügelsheim (Heiligenbuck), 45 Immendingen-Mauenheim, 46 Inzigkofen-Vilsingen, 47 TübingenBebenhausen. Switzerland: 48 Rances, 49 Ins. France: 50 Massalia, 51 Ste-Colombe-sur-Seine, 52 Apremont (Haute-Saône), 53 Franche-Comté, 54 Marainville-sur-Madon, 55 The Auvergne, 56 Paris Basin, 57 Courtesoult (Haute Saône). Britain and Ireland: 58 River Thames, 59 Teigngrace (Devon), 60 Roos Carr (Withernsea), 61 Ballachulish (Argyll), 62 Dagenham (Essex), 63 Shercock (Co. Cavan). Spain and Portugal: 64 northeastern Spain, 65 Galicia, 66 northern Portugal

the Heuneburg) and Po River (near the Etruscans); in migrating to North Italy, they allied with the Phocaean Greeks and helped establish Massalia. Important, too, is the relationship between Celts and Ligurians. Surviving in a much later text, the lost Massilliot Periplus (600 BC) placed Celts in coastal northern France beyond Brittany, on land taken from the coastal Ligurians (Table 4), suggesting that Celts 


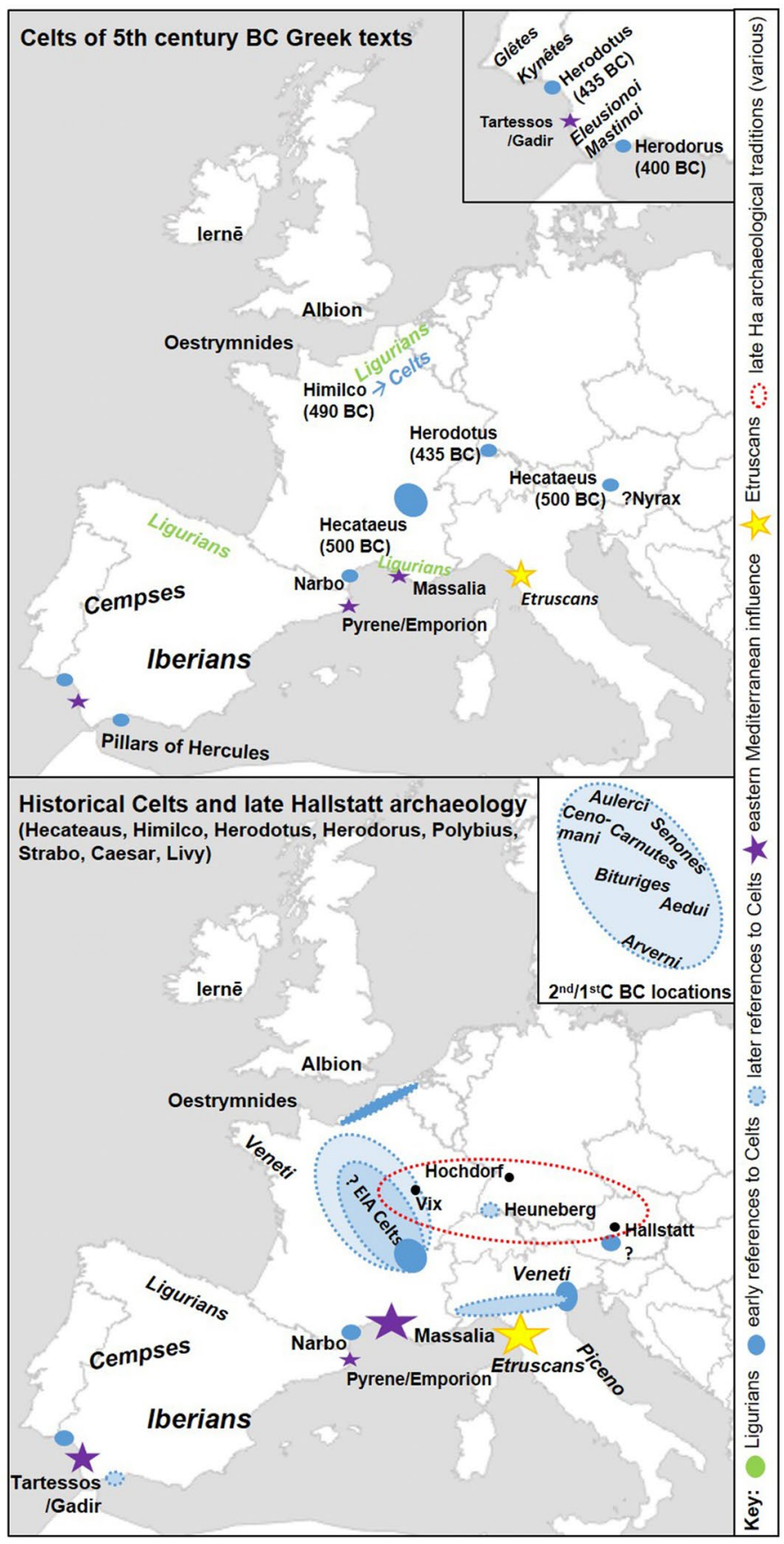

Fig. 4 Mapping fifth century BC textual references and the sixth century BC tribes of Polybius and Livy, via Strabo and Caesar (inset: after Collis 2003, figs. 20 and 55) to reveal the location of groups of people identified in shorthand as "Celts" (and their market settlements); note the overlap with western late Hallstatt archaeological traditions 
were initially inland rather than coastal groups (Sims-Williams 2016, p. 10). Ligurians were also recorded on the southern coast of France (Hecataeus, 500 BC) and in northern, coastal Spain (Himilco, 490 BC; Fig. 4). Ligurians, then, seems shorthand for coastal (non-Iberian) groups, as opposed to Celts who were initially those farther inland. By the time of Caesar, those of northern Gaul were "Belgae," from across the Rhine, while Celts, as they by then apparently called themselves, were again more central, a return perhaps to traditional landscapes.

The archaeology of $600 \mathrm{BC}$ reveals an established, well-connected, and equitable/ feminine Austrian salt trade, connected west to a thriving Heuneburg of high-status women (Hohmichele, Bettelbühl), where female burials outnumber males (39\% to $21 \%$ ) and burials were segregated by sex (Arnold 2012, p. 97). The Heuneburg was connected to the Magdalenenberg, south to the Mediterranean and west to an apparently matrifocal Gaul, where all high-status Ha D1 graves were feminine (Arnold 2012, p. 105; Milcent 2003; Pope 2018; Supplemental Table 2). The archaeology shows a new geographical focus between Danube and Seine (Fig. 3), perhaps supporting Livy, and a new trend through to LT B, with feminine graves the wealthier in western Germany/northeast France (Evans 2004; Trémeaud 2019, fig. 10). This emergence of matrifocal society seems to have been more short-lived in Germany than in Ha D1 France; it is not apparent in patrifocal Bavaria and is found only later farther east to Poland (Trémeaud 2019, p. 286; Supplemental Table 2). The period around $600 \mathrm{BC}$ seems to have been one of relative mobility, with long-distance connections attested in the grave goods of Hallstatt and some early movement perhaps from Austria to Bavaria (Pope 2018, pp. 7-8). After 616 BC, individuals of Hallstatt and North Italian heritage were buried at the Magdalenenberg, with a new love of Italian coral found in the west (Kruta 2005, p. 72; Oelze et al. 2012). The Heuneburg was rebuilt in Mediterranean style circa 600 BC (Krausse et al. 2016), and Livy's tale of Gauls moving to the Danube source at 600/590 BC fits well here. It should not surprise us that people traveled; indeed, the status item of late Hallstatt Europe was the wagon (Pare 1992; Piggott 1983), which both Powell (1958) and Cunliffe (1997) considered as having eastern, Ha C origins, with burnt wagon burials present in Late Bronze Age southern Germany (J. Collis, personal communication 2019).

Throughout the sixth century BC, the pattern of settlement in Bavaria to central France is one of small hilltop enclosures, with settlement focused in particular valleys (Büchsenseschütz and Mordant 2005; Collis 2003, fig. 72). Broadly 20 fürstensitze are known, in association with the increasingly wealthy fürstengräber of their occupants (Fernández-Götz and Ralston 2017). Meanwhile, pastoralist farmsteads formed around Bronze Age urnfields in the Netherlands, and contemporary early hillforts in southern England seem to have engaged only in pastoralism, with no formal burial tradition, except perhaps excarnation. In Britain, gender-ambiguous wooden figurines were deposited in natural, coastal locations, traditions relatively contemporary with the origin of formal Iron Age burials, including five women north of the Humber estuary (Melton) and a cemetery in Somerset (Supplemental Table 2, no. 239-245). In the texts, Polybius and Livy see continuation of smallscale migrations from Gaul to the Po source (Table 5), while wagon burials but few settlements are found in Switzerland (Kruta 2005, p. 46). The archaeology of early sixth century BC burials seems to document a relatively gender-fluid society 


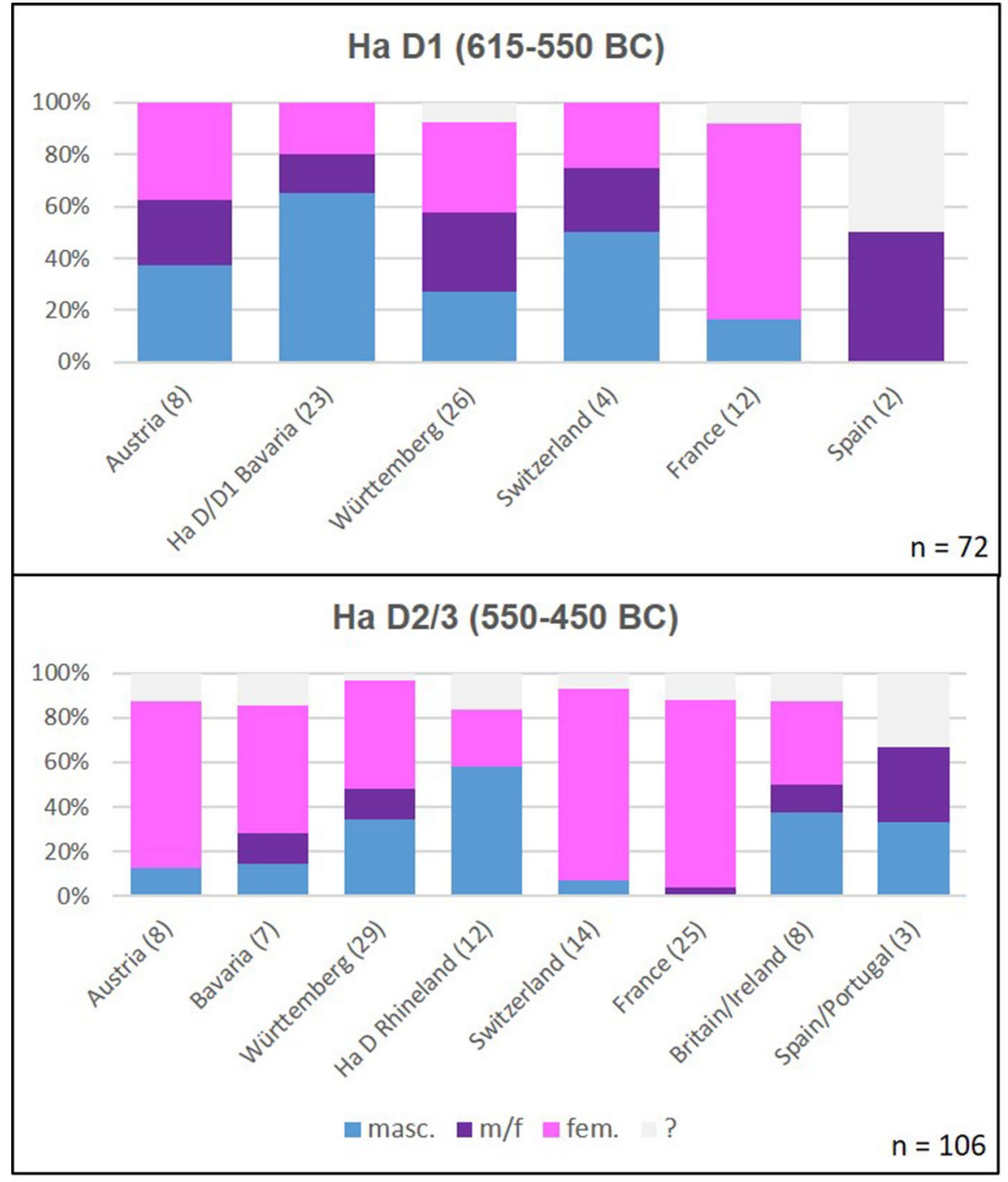

Fig. 5 The Ha D1-D2/3 transition $(550$ BC) as seen in the changing status of burial assemblages $(\mathrm{n}=$ 180)

in Germany, alongside matrifocal groups in France, with an increasingly feminine character to society after 550 BC (Burmeister 2000; Fig. 5). In the archaeology, we see late Hallstatt traditions adopted by those the Greeks called "Celts" in east-central France, with possible (social/kin) links east to Württemburg (Pope 2018, fig. 34.6). Leaving archaeology aside for the moment, I continue our quest for Celts by turning to the word of contemporary Greeks.

Our first contemporary classical references to Celts are found at $500 \mathrm{BC}$, as fragments of writing about early fifth century BC voyages that survived in later texts (Table 4). For Carthaginian explorer, Himilco, after the earlier Massaliot Periplus, 
Celts were on the coast of Gaul opposite Albion (Britain) beyond the Oestrymides (tin isles, considered here as the twin peninsulas of Brittany and Cornwall) on previously Ligurian land. This is perhaps confirmed in the Argonautica with a journey along a three-mouthed river (Po, Rhône, Rhine) to a vast area of stormy lakes in the land of the Celts. While Sims-Williams (2016) has the journey up the Po to the north Italian/Swiss lakes, if it continued down the Rhine-as indicated by the "three mouths" element (Collis 2003, p. 17)—we would meet Himilco's Celts on the north coast of Gaul. The Argonautica also has Celts inland of Ligurians in a journey down the Rhône (Sims-Williams 2016, p. 10). For geographer Hecataeus of Miletus (500 $\mathrm{BC}$ ), the keltikei, land of the Celts, was above (i.e., inland from) Massalia, a Phocaean colony in the land of the Ligurians (coastal southern Gaul). Finally, Hecataeus, a geographer, mentions a Celtic settlement at Nyrax that early French scholars thought, after Caesar, was Noreia/Noricum in Austria. This is disputed by Collis (2003, pp. 188-189) and Sims-Williams (2016), although an Austrian interpretation might make sense in a "trading outpost" model as a means of accessing salt. Hecataeus also mentions a "market settlement" at Narbo (thought to be Narbonne), although Collis believes Lattes (Montpellier) is the important Gaulish port (Collis, personal communication 2019; Powell 1958; Rankin 1996, p. 8).

So, for Mediterranean sailors at $500 \mathrm{BC}$, Celts were the people they encountered farther inland from the Mediterranean coast of France, with some perhaps also inland from the Adriatic (Hecataeus), including presumably those who occupied the small hillforts of central France (e.g., Mont Lassois). Himilco, and perhaps the Argonautica, also had Celts on the coast of northern Gaul, from Normandy to the Rhine. Interestingly, Brittany, as one of the Oestrymnides, seems neither Celtic nor Ligurian, its tin perhaps holding the land in common. Brittany was perhaps conceptually linked to its pair in Cornwall, which aligns with the settlement archaeology, as the presence of roundhouses distinguishes Brittany from the rest of France (Godard 2013). Early fifth century BC Celts, then, were primarily inland and non-Mediterranean, but with Mediterranean interests, as represented by traditional seventh/sixth century BC friendships with Masalliots and Etruscans and the "market settlement" of coastal Narbo (Fig. 4). This is the distribution largely accepted by Sims-Williams (2016, p. 24), a linguist who notes that these are the areas (North Italy, France, Switzerland) where Celtic language inscriptions (Lepontic, Gaulish) first appeared, with Lepontic dating from 600 BC (Koch 2019, p. 25).

In summary, while 20th century archaeologists (Déchelette, Kruta, Cunliffe) used "Celts" as a generic term for Iron Age Europe, this was not the case among early Mediterranean writers. A Celts-as-west trope can be found in later work (i.e., Ephorus) but only after the greater accuracy of the early term was already lost. Contemporary writers tell of Celts in central/northern Gaul from $500 \mathrm{BC}$, which Aristotle and Polybius subsequently extended back to the seventh/sixth centuries BC. This subsequent writing down of Celtic origin tales was presumably the result of their notoriety in the Mediterranean after 400 BC. The Early Iron Age archaeology of central France, the area of the Celts, is one of small hillforts, with burials that reveal people who were well-connected, traveled, and accumulated wealth in apparently matrifocal social structures. To help us further resolve the issue of the Celts, we turn to their relationship with the "Galatai." A long history of scholars conflated the two, 
assuming Galatai to mean those of Gaul. Here, following application of contextual method to both texts and archaeology of the Hallstatt-La Tène transition, we find that this is not the case. The archaeology suggests that as early as $550 \mathrm{BC}$, prior to our first Greek references, new social structures-the origins of the Galatai-were already beginning to form.

\section{Power Politics: Hochdorf, Vix, and Galatai (550-450 BC)}

\section{Origins of the Galatai? (550/540 BC)}

The archaeology reveals 550/540 BC as a politically significant time when settlement expanded north and south of the earlier Danube-Seine corridor (Fig. 6). In Württemberg, the archaeology reveals strong Mediterranean links, i.e., the Heuneburg architecture, Greek couch fittings and ceramics, and Etruscan drinking cups and local copies (Krausse et al. 2016), with some evidence in the early Heuneburg burials (Hohmichele, Bettelbühl) indicating that women had authority. The Heuneburg, however, suffered a major fire at 540/530 BC. The majority of the outer settlement was abandoned, and after 550 BC Württemberg burials reveal a decline in gender ambiguity, with the highest-status grave ultimately that of Hochdorf (Burmeister 2000; Fernández-Götz and Ralston 2017; Pope 2018; Fig. 5). While it is reported that Württemberg's neighbors to the west in northeast France-as Celtshad initial ties with Phocaean Greeks through Massalia, Gaul seems, ultimately, more connected to the Etruscans (northwest coast of Italy). Württemberg, on the other hand, saw initial influences from the Piceno region (northeast coast of Italy), e.g., the 600 BC Guerriero di Capestrano, which influenced both Hirschlanden and Hochdorf, before developing a stronger relationship with Greece. This relationship reached its zenith in the lifetime of Hochdorf (25 years old at $550 \mathrm{BC}$ ) and Grafenbühl (d. 500 BC), whose graves involved an ostentatious display of Greek furniture. Toward the end of this period, around $550 \mathrm{BC}$, some feminine grave assemblages had daggers/spears (Neuhausen ob Eck, Kappel-Grafenhausen T1, Stuttgart-Bad Cannstatt G1) as well as the first disproportionate deposition of curated feminine wealth (e.g., "matriarchal" Mühlacker, Esslingen-Sirnau), a practice that continued into the early La Tène period (Table 6). The martial material culture and rapid deposition of feminine wealth are signatures of unrest that, perhaps, are broadly contemporary with the Heuneburg fire and the ostentation of Hochdorf/Grafenbühl.

Contemporary, apparently matrifocal, eastern Gaul—the women of Ste-Colombe and Apremont buried beneath some of the largest barrows (70-80 m diameter) in western Europe-reveals less evidence for unrest at 550/540 BC, notwithstanding perhaps some migration to Champagne and North Italy. In Champagne, from 550 $\mathrm{BC}$, at the periphery of the late Hallstatt fürstensitze/furstengraber tradition, an austere Jogassian settlement was established and became densely populated by $400 \mathrm{BC}$ (Kruta 2005, p. 46). At Les Jogasses cemetery, graves were spatially segregated by sex (as at Hallstatt), and some women were buried with an iron dagger. The authority of Jogassian women is discussed by Milcent (2004, pp. 197-211), as high-status graves in eastern France became exclusively female (550-450 BC) and possessed 


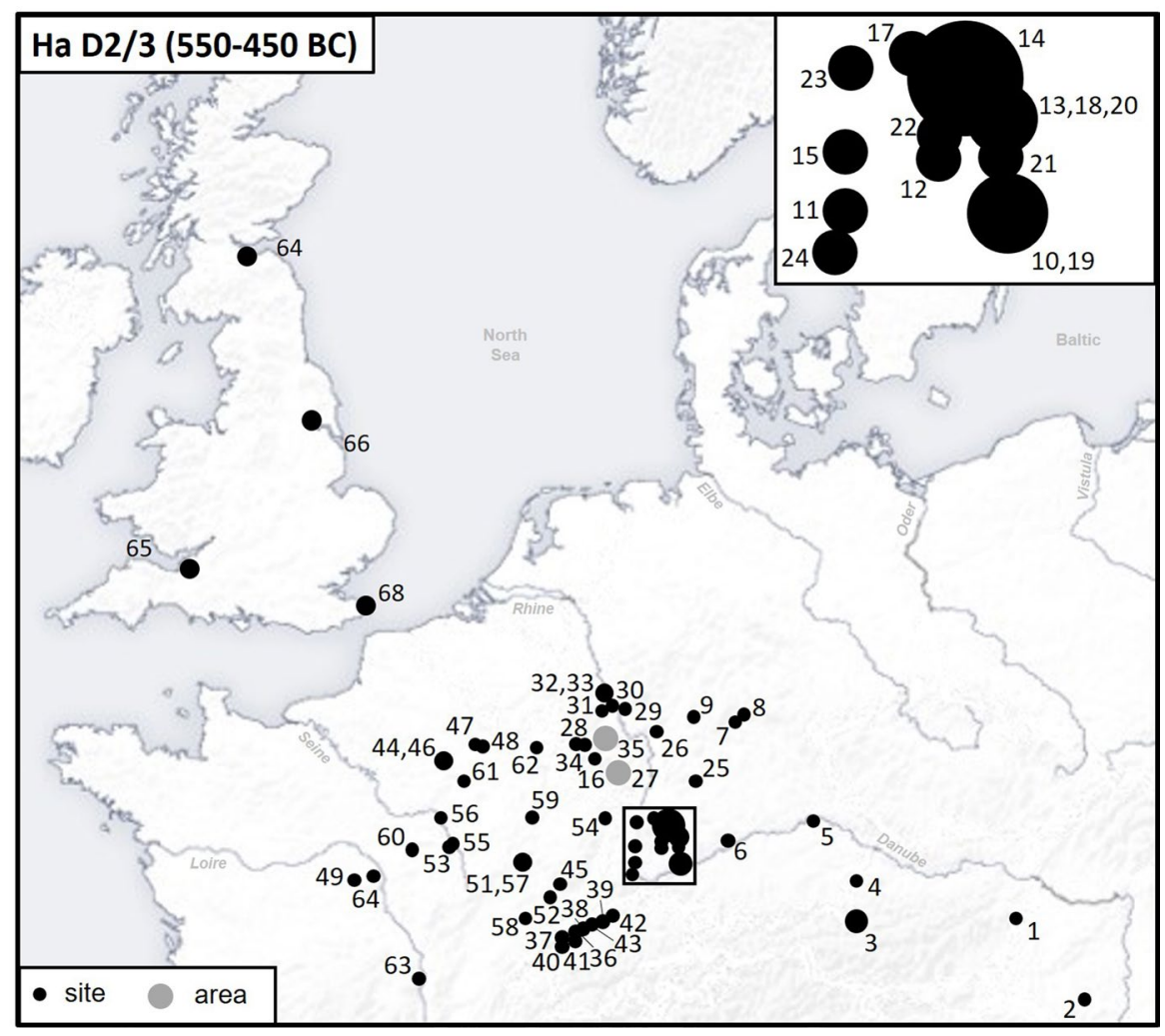

Fig. 6 Map of Ha D2/3 sites mentioned in the text (550-450 BC). Western Slovakia and Hungary: 1 Sopron, 2 Pécs. Austria: 3 Dürrnberg (Eislfeld, Hexenwandfeld, Simonbauernfeld), 4 Helpfau-Uttendorf "Moos." Bavaria: 5 Straubing, 6 Dillingen-Kicklingen, 7 Schesslitz-Demmelsdorf, 8 Weismain-Görau, 9 Leinach-Oberleinach. Württemberg: 10 Heuneburg (Speckhau, Gießübel-Talhau, Herbertingen-Hundersingen [Gießübel]), 11 Kappel-am-Rhein, 12 Dußlingen, 13 Stuttgart-Bad Cannstatt, 14 Hohenasperg (Ludwigsburg-Römerhügel, Ditzingen-Schöckingen, Hirschlanden, Hochdorf, Kleinspergle, Grafenbühl), 15 Nordhouse (Bas-Rhin), 16 Hochwald-Nahe, 17 Mühlacker, 18 Esslingen-Sirnau, 19 ZweifaltenMörsingen, 20 Hegnach, 21 Erkenbrechtsweiler, 22 Stuttgart-Weilimdorf, 23 Söllingen, 24 Breisach am Rhein-Gündlingen, 25 Kirchberg and der Jagst-Lendsiedel. Rhineland: 26 Offenbach-Rumpenheim, 27 Middle Rhine-Moselle, 28 Elm-Sprengen, 29 Schwalbach, 30 Oberlahnstein, 31 Niederweiler, 32 Bell, 33 Hundheim, 34 Wallerfangen, 35 Hunsrück-Eifel. Switzerland: 36 Allenlüften, 37 Payerne, 38 Grächwil, 39 Adiswil, 40 Châtonnaye, 41 Düdingen, 42 Unterlunkhofen, 43 Urtenen. France: 44 Les Jogasses, 45 Ensisheim (Alsace), 46 Chouilly J., 47 Aure, 48 Manre, 49 Paudy "Ste-Favrille," 50 Champagne, 51 Savoyeux, 52 Grandvillars, 53 La Motte de Cérilly, 54 Diarville, 55 Vix, 56 Lavau, 57 Mercey-surSaône, 58 Forêt des Moidons (Chilly-sur-Salins), 59 Hatten, 60 Gurgy (Yonne), 61 Heiltz-l'Évêque, 62 Mondelange (Metz, Lorraine), 63 Le Pâturel (Auvergne), 64 Bourges. Britain: 65 Dibble Farm (Christon, Somerset), 66 Melton, 67 Newbridge (Edinburgh), 68 Cliffs End (Kent)

most grave wealth until the LT B1 period (375 BC) (Supplemental Tables 3-4; Pope and Ralston 2011, p. 381; Trémeaud 2019, p. 286). The adoption of late Hallstatt (Württemberg-Greek) traditions in central-eastern France perhaps inspired some women to move north, with contemporary Brittany (tin source) instead influenced by North Italy (Kruta 2005, p. 52). As Württemberg became friendly with Greece, 


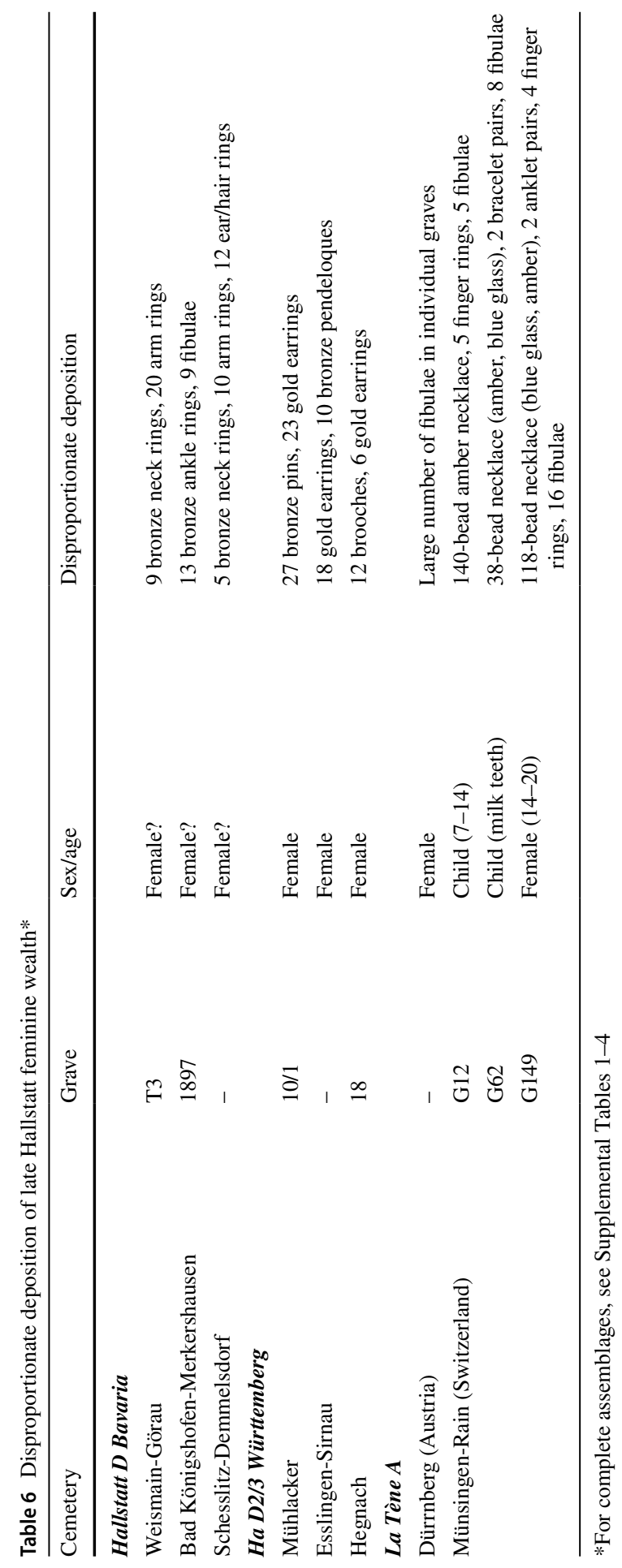


the long-established links between Celts and Etruscans/North Italy ultimately became more binding. From classical authors, we heard how Celts in North Italy continued to be joined by additional groups from Gaul (Table 5).

In neighboring Rhineland, the archaeology reveals a society different again from both Hochdorf's Württemberg and Jogassian Champagne. By contrast, Rhineland barrow cemeteries have excess men (1 feminine to 7 masculine); wagons and highstatus goods were predominantly buried with men, typically with spears (Fig. 5b), with Trémeaud's (2019) analysis revealing a surge in masculine grave wealth after 550 BC (see Fig. 2). The archaeology reveals these more masculine, northern groups to be much less concerned with displaying Mediterranean contact. The impression is of male authority, greater insularity, and a concern for martial identity over wealth display, a new austere social order in which women played a lesser role. Interestingly, it is here, toward the end of the Hallstatt period, when chariots are first found in Hunsrück-Eifel west of the Rhine, at the same time that the number of status burials increased (after 475 BC) in Rhine-Moselle (Pope and Ralston 2011, p. 384).

A new martial masculinity is also found in Bavaria, whose elder Ha D1 men had instead prized their appearance (Ha D1 grave goods included toilet sets, razors, tweezers). The majority (85\%) of Pare's (1992) "Ha D" Bavarian wagon burials, however, had typically masculine grave goods, and, as in Rhineland, this masculinity now displayed a martial identity ( $82 \%$ had weapons). As in Rhineland, these groups in Bavaria were less concerned with displaying Mediterranean contact; while there is limited evidence for some continuity of contact, Bavarian tradition instead preferred feasting from ceramics (e.g., Großeibstadt I G4 and his 56 vessels). In Bavaria, however, unlike Rhineland, some of the wealthiest wagon burials were feminine (e.g., Schesslitz-Demmelsdorf with five bronze neck rings, five pairs of arm rings, amber, and gold); this is a further example of disproportionate deposition, in which tokens of absent female relatives were displayed, perhaps, as some women left family behind in the late Hallstatt heartland. Also of interest are the depictions of a 50:50 representation of men and women on Bavarian vessels (RebaySalisbury 2016).

The archaeology shows $\mathrm{Ha} \mathrm{D} 2 / 3$ as a time of population growth; new settlements and 400 cemeteries were established to the north in Rhineland/Champagne, with tens of thousands of graves (Brun 2018, pp. 12-13; Fig. 6). Both texts and archaeology reveal 550/540 BC as a period of movement (Fig. 7), north and east out of late Hallstatt traditions (to Bavaria, Rhineland, Champagne) and south to North Italy. This movement apparently was gendered by region-feminine in Champagne (among matrifocal groups), masculine in Rhineland (among patrifocal groups), and mixed in Bavaria. These new, northern communities reveal martial identities: daggers with Württemberg/Champagne women, spears in Rhineland/Bavaria. Groups perhaps fought their way out of late Hallstatt society, whether literally or metaphorically. There also was movement to already established communities: eastern groups to Bavaria and Celts to North Italy. Among older communities (Württemberg, Bavaria), Hallstatt-derived wealth was rapidly deposited, indicating fractured communities where family items were deposited instead of passed on. There was similarly high feminine grave wealth in northeast Germany/Poland from Ha D2/3-LT B (Trémeaud 2019, pp. 286-289). This seems to have been a period of upheaval that 


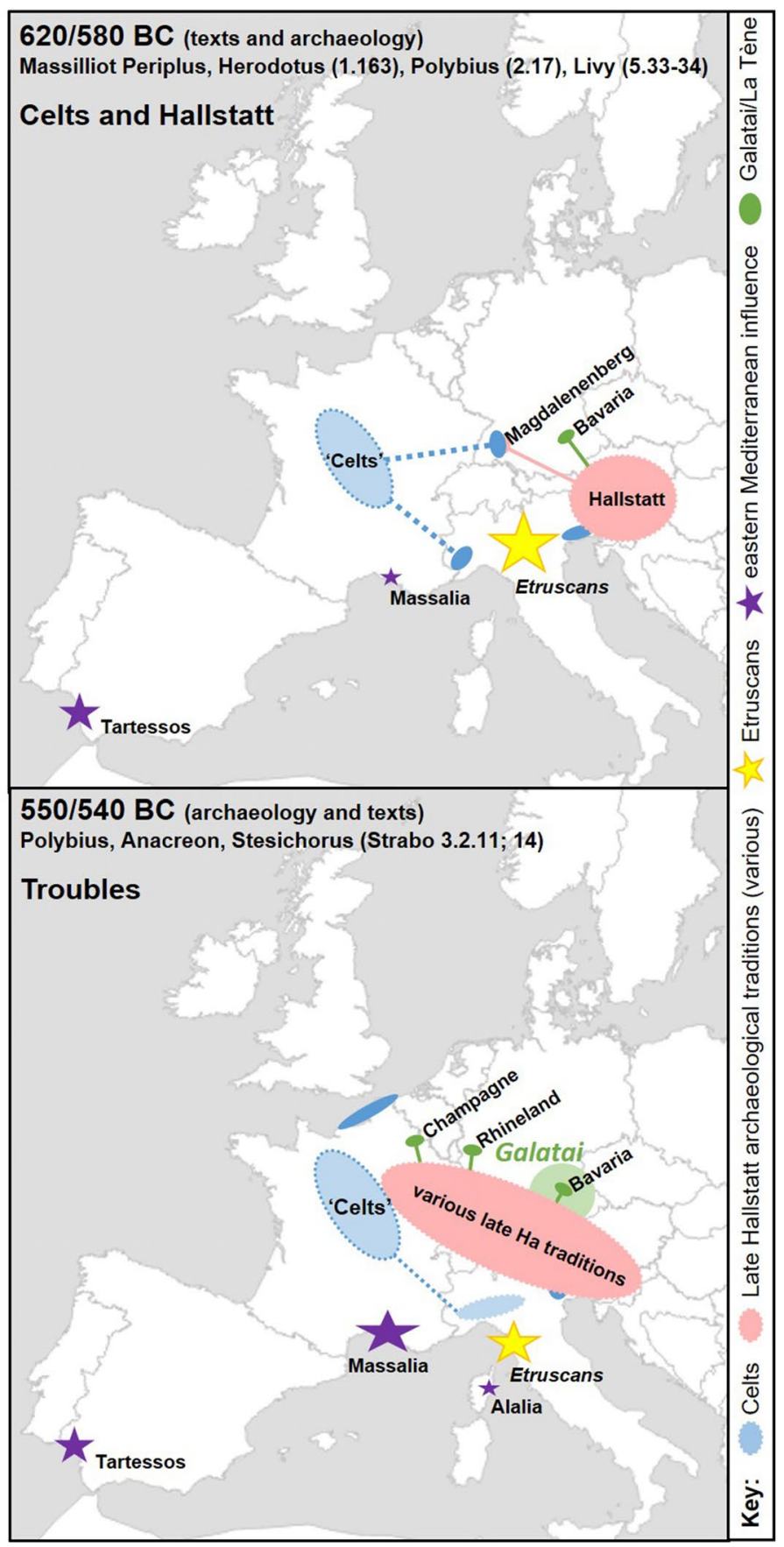

Fig. 7 Temporal maps (620-540 BC): integration of evidence from texts and archaeology (note: the shapes on the map do not represent culture groups; they are artifacts of archaeological and textual data only) 
necessitated a realignment of communities (people either stayed, left to join cousins, or started afresh in the north), presumably on the basis of shared values.

At this time in the Mediterranean, Persia had absorbed eastern Greek settlements, leading Phocaeans to migrate west to Alalia: their colony established on east-coast Corsica in 565 BC (Cunliffe 1997, p. 50; Hornblower et al. 2012). This upset Etruria, and in $535 \mathrm{BC}$, an Etruscan-Carthaginian alliance expelled Phocaeans from Alalia. In the 530s BC, during Hochdorf's lifetime, the western Mediterranean might be interpreted as increasingly "anti-Greek." Contemporary martial assemblages in northwest Europe (Württemberg, Rhineland, Bavaria, Champagne) alongside Polybius' migrations suggest a rejection, by some, of late Hallstatt values (Hochdorf's lavish wealth, Greek alliance), perhaps especially for Celts with their long-held Etruscan allegiances. Alongside the disproportionate deposition of feminine Hallstatt wealth in Württemberg and Bavaria, it is out of the new, northern and eastern communities that we see the very origins of new La Tène societies after 550 BC: those known to Greek writers as "Galatai" (see below).

\section{The Political Vix (520-450 BC)}

Following this period of political upheaval, we find the grave of Vix (Burgundy), often considered the wealthiest burial in western Europe. The status of the associated settlement of Mont Lassois was inherited, perhaps, from the woman of SteColombe de la Butte, $5 \mathrm{~km}$ to the south, whose 76-m-diameter tumulus was paralleled only by Hohmichele. Vix, in life, was very much in the center of things. Mont Lassois was strategically positioned near the heads of both the Seine (north to Atlantic tin) and the Rhône (south to Phocaeans at Massalia and the Mediterranean). Geographically, Vix was at the overlap of Celtic identity to the west and Württemberg influence to the east, a cultural overlap that may have inspired early moves to North Italy. Politically, Vix was born as Etruscans and Carthaginians were expelling Phocaeans from Alalia. Despite Gaul having Phocaean connections through Massalia (e.g., the Megaron-type house of Mont Lassois), on her death Vix appears to have asserted anti-Greek sentiments. At 500 BC her Württemberg contemporary, Grafenbühl, displayed Greek furniture, akin to earlier Hochdorf. The tomb of Vix contained the largest Greek krater-symbol of the masculine Greek symposion (Hobden 2016) — in all of Europe and the Mediterranean. This krater, however, subverts, with unusual, leg-spreading, terrifying gorgon imagery at the base of the handles. The usual parade of soldiers on the lid/sieve rim had been removed (and was not recovered in Joffroy's excavation), and instead, at the lid's center, was soldered an Italian bronze figure of a woman (Rolley 2003). On one of the two Attic cups, women (Amazons) were fighting Hoplites. The material culture of Vix's tomb reads as a subversion of the Greek symposion, an assertion instead of female authority, referencing back perhaps to Etruria via the Italian female figure. From Hecataeus, the Celtic market settlement of Narbo was established during the life of Vix, perhaps revealing an attempt by Celts, at this politically charged time, to circumvent Massaliot middlemen in the trade to the north-assuming a greater role perhaps in the trade of Brittany's tin. So, in the generation following the unrest of 550/540 BC, 
our "Celts" seem to have avoided greater conflict by restating Etruscan over Greek allegiances. At this time, Livy has more Celts moving to North Italy-which now makes more sense in political context - and ultimately fighting Etruscans for land (Table 5).

The political resolve of Vix, restating Etruscan over Greek allegiances, seems to have survived for two generations after her death, coming undone only at $450 \mathrm{BC}$. It is interesting that we have no surviving contemporary Greek texts of this period, particularly given that the archaeology suggests an era of female political authority. Two subsequent stories-Diodorus Siculus on the foundation of Gaul and Plutarch writing in $\mathrm{AD} 100$ on the judicial role of Celtic women in matters of war-can be read as regarding the political situation at the time of the Vix burial (Hist. Lib. 5.24; Mulierum Virtutes 246c). Each text highlights the respect for the political role of Celtic women in late Hallstatt-early La Tène society.

\section{Decline of Hallstatt and the Celts (450 BC)}

In the Mediterranean, Etruscans allied with Carthage against the Phocaeans and saw trade flourish after 480 BC (Cunliffe 1997, p. 51, 62). This, however, led to conflict, e.g., a Syracusian offensive against coastal Etruria (454/453 BC). Meanwhile, the female-led unrest in Württemberg seems, three generations on, to have spread farther west, particularly among men. In the archaeology of Rhineland and Champagne, the earlier Rhine-Moselle pattern (550/540 BC) was repeated at $450 \mathrm{BC}$ with a new martial identity in Hunsrück-Eifel. There, the wealthiest La Tène A burials were masculine (Hochscheid, Bescheid), and there is a notable absence of wealthy women north of the Moselle, suggesting that patrifocal groups shifted farther north again, as the traditional late Hallstatt heartland was abandoned (Fig. 8). In Champagne, too, a new association existed between men and chariots, particularly in the earliest examples, with a new growth of masculine status display alongside the established wealthy women of Champagne (Supplemental Table 3, no. 278). By 450 $\mathrm{BC}$, it seems to have been the men who led the final social move out of late Hallstatt traditions, alongside the breakdown of late Hallstatt gender norms (Fig. 9a). Importantly, our well-documented "shift north" at $450 \mathrm{BC}$ was in fact a continued move out of the Ha D1 Danube-Seine corridor, a political move that it seems was originally led by women as well as men, something we had missed due to our previous lack of interest in female graves.

"Celts," then, were caught up in broader social change as the social transition from Hallstatt to La Tène began to snowball. Late Hallstatt traditions east to Germany, as embraced by the eastern Celts, were dying. By $450 \mathrm{BC}$ the Heuneberg was abandoned, Greek trade had ended, and late Hallstatt grave assemblages were becoming ritualized. In Gaul, movement to North Italy continued, with Italian material culture dating later farther west (e.g., Bourges); at the same time others appear to have joined the now well-established northern communities. As had happened in neighboring Moselle-Rhine (after 475 BC), alongside masculine burials with swords/spears, the northern communities (e.g., Champagne) saw dramatic growth in Early La Tène feminine wealth after 450 BC. The 


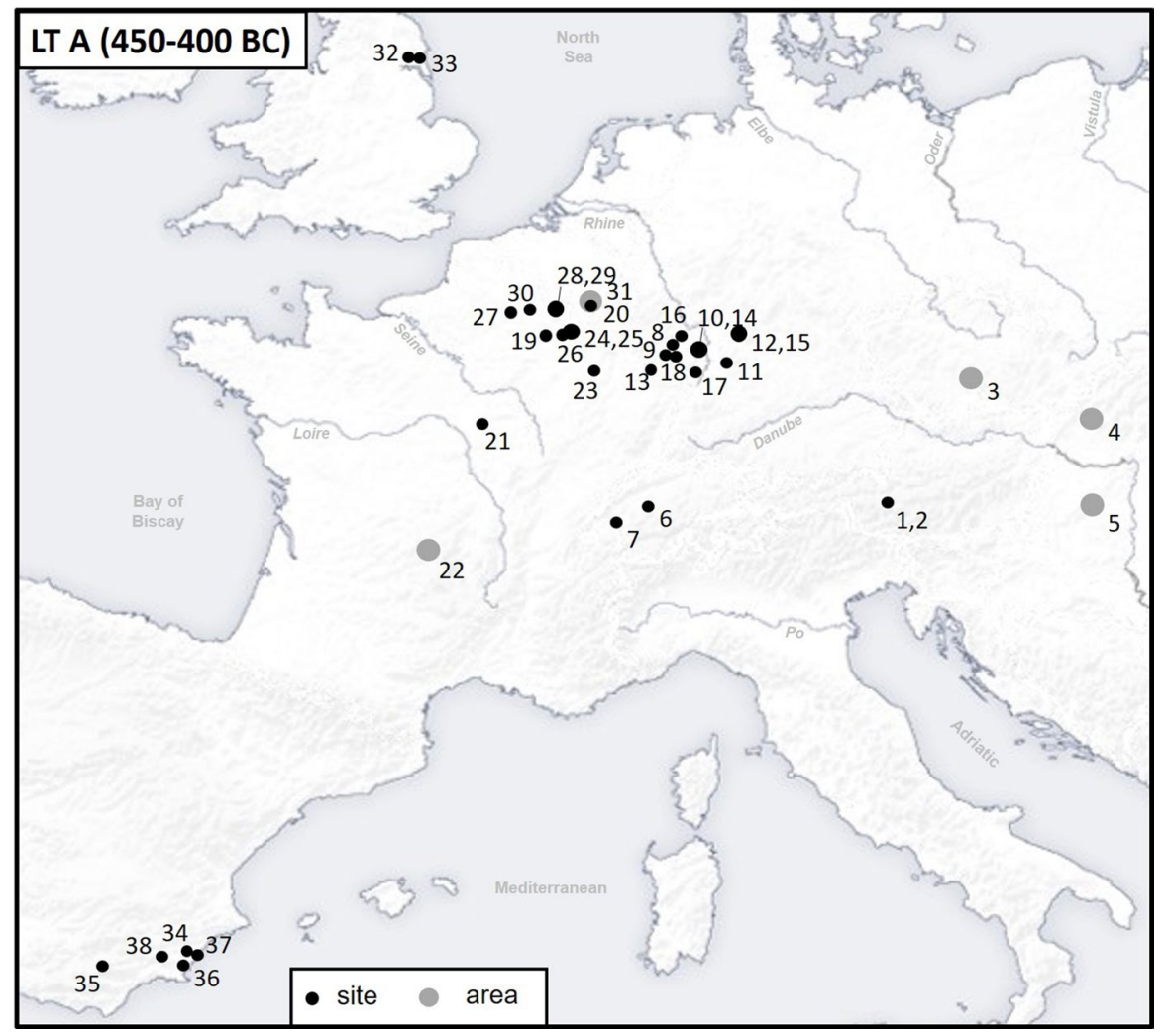

Fig. 8 Map of La Tène A sites mentioned in the text (450-200 BC). Austria: 1 Dürrnberg, 2 Hallein. 3 Bohemia. 4 Slovakia. 5 Hungary. Switzerland: 6 Münsingen-Rain (85), 7 Saint-Sulpice (Vaud). Hunsrück-Eifel: 8 Hochscheid, 9 Bescheid. Middle Rhine: 10 Worms-Herrnsheim, 11 Reinheim, 12 Rodenbach, 13 Besseringen, 14 Bad Dürkheim, 15 Glauberg, 16 Pfalzfeld, 17 Holzgerlingen, 18 Hoppstädten. France: 19 Vert-Toulon, 20 Lèglise, 21 Route de Dun (Bourges), 22 The Auvergne, 23 La Motte-SaintValentin à Courcel-les-en-Montagne (Haute-Marne), 24 Somme-Bionne, 25 Somme-Tourbe, 26 Châlonsur-Marne, 27 Pernant, 28 Berru, 29 Prunay, 30 Bucy-le-Long (Aisne), 31 Belgian Ardennes. Britain: 32 Wetwang Slack, 33 Danes Graves. Spain: 34 Elche (Alicante), 35 Baza (Granada), 36 Guardamar, 37 Cabezo Lucero (Alicante), 38 El Cigarralejo (Mula, Mercia)

graves display late Hallstatt jewelry - torcs, bracelet pairs, earrings; while graves of contemporary "Senones" women of the Adriatic also displayed torcs and bracelet pairs (Evans 2004; Kruta 2005, p. 70; Verger 1995). Interestingly, with only $13 \%$ infant burials during this period (Marne, Pernant cemeteries), early La Tène women seem to have been in control of their fertility, and Roualet (1997, p. 170) considered this new northern society to be "egalitarian." Similarly, contemporary Middle Rhine saw incredible female wealth (gold, Schnabelkannen) as Late Hallstatt traditions came to an end in the early La Tène period. This process involved slightly odd, potentially ritualized imagery/behavior: miserable warriors in a North Italian defensive stance; mistletoe headgear (Hirschlanden, Glauberg); a young boy of status (Hoppstädten); high-status women displaying North Italian 


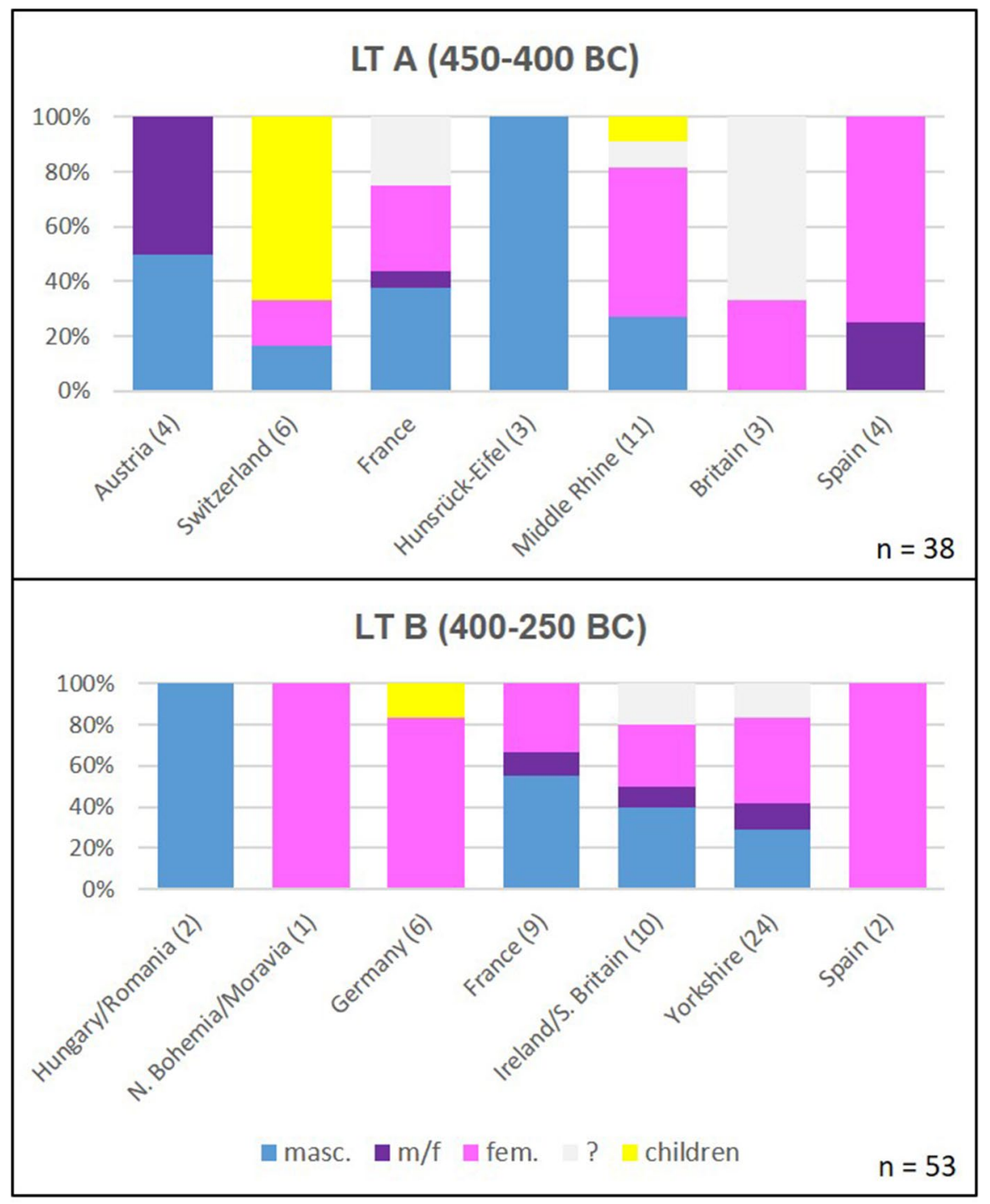

Fig. 9 The LT A-B transition (400 BC) as seen in the changing status of burial assemblages $(\mathrm{n}=91)$

links (Reinheim, Waldalgesheim)—a continued regret perhaps for Greek alliance and perhaps also for a loss of the Celts.

Alongside growing wealth in the northern communities of the Middle Rhine and Champagne, the archaeology of those who lived closer to the older salt communities, in Austria/Switzerland, shows rapid deposition of extraordinary female wealth, contemporary with the decline of late Hallstatt traditions in Germany (Table 6). In Dürrnberg, women received a disproportionate number of fibulae on burial, as the community actively deposited inherited wealth in its move away from feminine late Hallstatt power 
structures. In Switzerland, we find notably austere masculine graves, with relatively plain iron swords; children were buried with objects of female wealth, referencing adult elite themes and Etruscan contact, a notable development from late Hallstatt traditions that had celebrated middle-aged achievement and leadership. It was previously unrecognized that it was actually dead children who received feminine wealth (Fig. 9a; see Pope and Ralston 2011, p. 378). As seen first in Württemberg/Bavaria, these ostentatious grave assemblages seem to mark the deposition of an accumulated wealth of generations, representing a society that was shrinking rather than growing, as heirlooms were deposited rather than inherited. The older traditions were dying with the parents. Contemporary with this is the accumulation of large depositions of weaponry and animal remains at ritual sites (La Tène, Gournay-sur-Aronde, Ribemont-sur-Ancre), the masculine equivalent of the feminine graveside practice of deliberate deposition.

The late Hallstatt celebration of wealth, originating out of the salt trade, was in very rapid decline at $450 \mathrm{BC}$. Pockets of fast deposition, inside a generation, reveal that the objects of female wealth were no longer being passed on in socially fractured, martial communities where status remained ungendered, but where leadership was now less obviously the preserve of women. Identity on death celebrated martial ideologies/ traditions, presumably those that had begun a century earlier under Hochdorf. Earlier individual migrations (to Bavaria, Rhine-Moselle, Champagne) seem to have occurred again, now farther west and north (e.g., Supplemental Table 3, no. 287, 294), after which followed greater female wealth display/deposition, traditions that still demonstrated links to Italy amid cessation of Greek trade. Female wealth was deposited in areas of France, Switzerland, Austria, and the middle Rhine. Younger women at 450 $\mathrm{BC}$ seem to have accepted the end of Hallstatt traditions, something their Celtic great grandmothers had perhaps refused to do at 550/540 BC under Ste-Colombe and then Vix. A century after the upset of Hochdorf, more Celts joined the original move north. Others perhaps moved west (e.g., to Bourges) or south to join relatives in North Italy, as the archaeology seems increasingly to have verified (Cunliffe 1997, p. 73; Kruta 2005, pp. 66-67, 72; Vitali 1997).

What we can establish, then, from the archaeology, is the slow development of new, northern communities that formed across 550-450 BC out of late Hallstatt traditions. This was not a mass-migration but a slow process of groups of people changing politically and socially across three to four generations and shifting their settlement over time. This insight is provided only by a refined, chronologically sequenced understanding of both archaeology and texts. These newer, northern communities who developed the La Tène art traditions became known to Greeks as Galatai: sort-of-Celts, but not quite. I now turn primarily to the texts to further our understanding of Galatai and their relationship with the Celts. I begin with Herodotus, who documented Celts after the $450 \mathrm{BC}$ shift to the north, on the moment of their decline. 


\section{Making Sense of a New Era}

\section{Relocating the Celts (435-400 BC)}

Greeks of 500 BC understood Celts as from central Gaul, with some also dotted at points along various coasts (Fig. 4). Rather than "Celts" referring broadly to western Europe, akin to the Greek Hyperborean trope, Celts were noted at specific locations. By 435 BC, Herodotus recorded a Celtic market settlement on the south coast of France and another coastal group in southwest Spain; by 400 BC Herodorus of Heraclea placed an Iberian Kelkianoi tribe, the name suggesting Celtic links, slightly farther east. Groups of Celts had settled the Mediterranean coast, presumably to access Massalia, Emperion, Tartessos, and Carthage. In linguistics, we initially tried to push these coastal Celts of Herodotus and Herodorus from the Pillars to the Pyrenees to account for third century BC Celtic linguistics farther east; now other scholars accept fragments of an early Celtic language surviving in southwestern Spain (Cunliffe and Koch 2019; Sims-Williams 2017). It is the latter that now seems more in agreement with the contextualized texts.

Herodotus also had Celts at the Danube source, perhaps 15 years after we now think the Heuneburg was abandoned (Krausse et al. 2016), betraying a Greek need to document, perhaps, on cultural decline. The context is Herodotus seeking to correct a misunderstanding that had crept into Greek knowledge in the 470s/460s BC under poets Pindar and Aeschylus, that the Danube source was Hyperborean (Pyth. O. 3.10; Collis 2003), a poetic extension of the people-fromthe-north/Hyperborean trope that was repeated by historian Hellanicus toward the end of the fifth century BC (Dinan 1911, p. 26). Historian and stickler Herodotus sought to correct this poetic geography, reasserting the area as Celtic, not Scythian, and showing how early poets Hesiod (750 BC) and Aristeas (seventh century BC) had Hyperboreans farther east, with the Danube source instead in the land of the Celts, ek Kelton. Livy's 600 BC migration of Celts to the Danube source can be seen as supporting Herodotus here, and Herodotus perhaps understood something of the history of the Heuneburg, as Hecataeus knew Nyrax. If so, Herodotus believed that Heuneburg traditions, then dying, had included Celts, which, given the relatedness of the archaeology, seems entirely reasonable (see Pope 2018). So, despite later, Roman use of "Celts" as a geographical trope for west, we find early Greek writers understanding Celts ethnographically as from central Gaul and different from Iberians and Ligurians, with small groups settling east to the Danube source and south to the Mediterranean coast.

Herodotus has the Danube source near a polis named Pyrene, something that has created much confusion (see Sims-Williams 2016). There are three key interpretations: first, that it is the Pyrenees, leading scholars to suggest Herodotus was referring to Emporion, meaning his geography was wrong: his "imagined" Danube (cf. Collis 2003, p. 126; Cunliffe 2012; Sims-Williams' 2016, p. 17). While Aristotle's poor geography is accepted, this is disputed for Herodotus (Dobesch 1997). One solution is that, if referencing the Pyrenees, Herodotus was not being geographically literal but was employing a device to labor a western rather than 
northern source to his reader, which makes sense in the context of the incorrect poetic geography. The second is that the Heuneburg is Pyrene (Krausse et al. 2016); this is problematic given that Pyrene is located in the Massaliot Periplus on the coast west of Massalia, i.e., Pyrenees/Emporion (Collis 2003, p. 126; although notably not mentioned by Pseudo-Skylax). Dinan (1911, p. 30) suggests that use of Pyrene was a mistake, noting that it was written out of a later extract, highlighting Herodotus himself saying: "concerning the western extremities of Europe I cannot speak with certainty" (Hist. III.115). Perhaps, most simply, Herodotus got the location (Danube source) right but the name wrong. In summary, Pyrene was Emporion; Celts were at the Danube source (Heuneburg); and Herodotus, in his laboring west over north to correct the poets, initially confused the two (see Rankin 1996, p. 9).

Following Herodotus, we hear less on Celts during the time of the Peloponnesian War (431-404 BC). In the archaeology of 430/425 BC, however, a generation on from the $450 \mathrm{BC}$ male chariot burials of Hunsrück-Eifel/Champagne (newer communities) and deposition of feminine wealth in Austria/Switzerland (older communities), there is growing grave wealth among Champagne women, with martial masculine assemblages again farther north and west (Aisne-Marne, Upper Seine). Traditional status items (torcs, daggers) were replaced by those of combat (helmets, spears). Throughout 425-400 BC, Champagne saw more chariot burials, but proportionate now between men and women, with burials in family groups rather than in late Hallstatt/Jogassian sex-based clusters, a different social norm. Meanwhile farther east at Dürrnberg, alongside continuity of Hallstatt traditions (balanced gender rules, Greek contact) we see helmets, as in Marne. The archaeology reveals a continuing martial identity (burial with weapons) that began in late Hallstatt southern Germany/eastern France. By 430 BC, this identity had touched even the old salt communities and farther east to Hungary (Kruta 2005, p. 58). This "martial identity" may reveal active combat, or it was perhaps more a continuing cultural reference, on death, to the events of 550/540 BC and $450 \mathrm{BC}$.

So, at a time of war in the Mediterranean, martial identities also flourished in Europe. At 425-400 BC, we find female chariot burials in western Aisne-Marne, as far west as the Belgian Ardennes, with a lone outlier at Newbridge, south of the Forth estuary in Scotland, while two "Scandinavian" women were buried at Cliffs End, Kent. So, too, began the Dama statues of southeastern Spain (Supplemental Table 2, no. 246-247), and this potential for a western survival of Celtic identity perhaps fits the linguistics (Sims-Williams 2020, p. 13). Disruption of Italian trade is seen in German/Austrian archaeology at $400 \mathrm{BC}$, although dying Hallstatt traditions reveal that some contact, or perhaps an heirloom factor, may have continued to $350 \mathrm{BC}$ at Waldalgesheim (Arnold 1995a, p. 51; contra. Cunliffe 2001, p. 315; Supplemental Tables 3-4). After 400 BC, the Celts of the Greek writers (Timagetus, Theopompus, Xenophon) refer exclusively to those of North Italy (Table 4) as allying with Sicilians against Athens in 415-413 BC, reflecting their older political allegiances. Polybius and Livy tell of additional groups traveling from Gaul to North Italy throughout the fifth century BC, ultimately taking all land between the Alps and the Po and the Adriatic coast, as confirmed by Pseudo-Skylax (Tables 4, 5). Livy says the final group, the Senones of Champagne, settled down as far as Ravenna and 
came to Clusium seeking land (Table 5). More than two centuries, eight generations after the first small groups settled in North Italy, the decline of Late Hallstatt society in Gaul saw Celts without enough additional land in North Italy to settle. These were the ultimate "Celtic migrations" that attracted the attention of Rome, arguably changing the course of history following its sacking in 390/387 BC.

\section{Celtic Migrations}

What of the descendants of the original Celts in Gaul, prior to the occupation of Rome (387 BC). The settlement archaeology of $400 \mathrm{BC}$ reveals the decline of communal sites in Europe; late Hallstatt society had lasted 200 years before becoming lost to politics (Collis and Karl 2018; Fernández-Götz and Ralston 2017; Milcent 2014). Meanwhile, the burial archaeology of the newer, northern settlements reveals whole areas deserted at 400 BC (Rhineland, Marne, Bercy, Champagne, S. Bohemia; Supplemental Table 4). Champagne saw a shift from 162 active cemeteries in the late fifth century $\mathrm{BC}$ to just 36 in the first decades of the fourth century BC (Fernández-Götz 2020, p. 193), a depopulation, with the new northern communities disbanding within 150 years of their origins (Fig. 10). The late move out of late Hallstatt traditions at 450/430 BC was temporary, surviving only a generation. This well-recorded and male-led "shift north" to the newer northern communities - that had been established at 550/540 BC, by women in Gaul and men in Germany-seems not to have worked socially and broke down by $400 \mathrm{BC}$. The area of Champagne that remained populated (Reims) had cemeteries with few men and lavish feminine graves; half the community was buried with bronze torcs, and highstatus contact was now exclusively with Italy. Arnold's (1995b) argument for female authority as linked to male absence might hold most currency here, with Roualet (1997, p. 170) suggesting a matriarchal society. The women had stayed.

This seems to be an archaeology of the historically documented migrations at their 400 BC peak. Men in particular apparently left the newer northern settlements, moving north again to the Aisne Valley, Seine/Paris basin, and south to North Italy, where half the men in contemporary "Senonian" cemeteries had swords, some La Tène (Collis 2003, p. 137; Kruta 2005, p. 66, 85). Instead new, male-dominated groups in the Seine basin and East Yorkshire (Kirkburn) reveal a decline in female welfare, including evidence for stillbirths and higher than average neonate/infant deaths at Kirkburn, suggesting perhaps an absence of elder female knowledge (Giles 2012, pp. 92-95; Pope and Ralston 2011, p. 388). Rather than mass-migrations, however, isotope work in eastern Britain currently suggests only a few nonlocal individuals in Kent, with signatures in Yorkshire predominantly local (Green 2008; Jay and Montgomery 2020; McKinley et al. 2014). The British settlement evidence points to more substantial social change, specifically at around $400 \mathrm{BC}$, with the swelling of developed hillforts alongside a marked increase in the number of farmsteads, and social agglomeration in the lowland pastoralist settlements of Denmark and eastern England (Pope et al. 2020; Pope and Haselgrove 2007, p. 8). Although the chronology of the British La Tène period is an ongoing project, there are also hints of a potential western survival of some Celtic traditions. These 


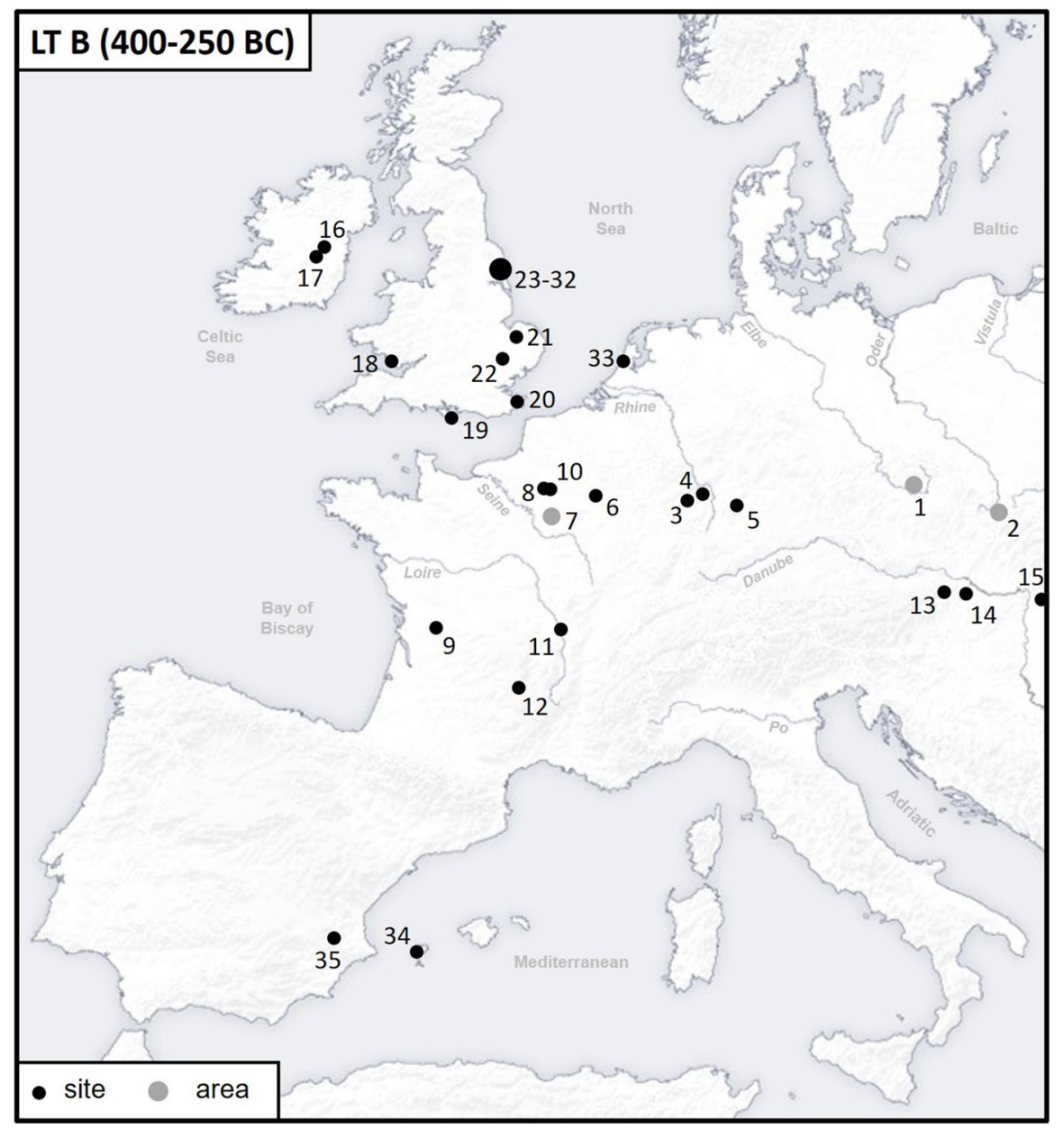

Fig. 10 Map of La Tène B sites mentioned in the text (400-250 BC). 1 northern Bohemia. 2 northern Moravia. Germany: 3 Bescheid, 4 Waldalgesheim, 5 Nebringen. France: 6 Reims (Champagne), 7 Seine basin, 8 Epiais-Rhus (Paris), 9 Agris, 10 Plessis-Gassot (north of Paris), 11 Aulnat (Auvergne), 12 Bozouls (Aveyron). Austria: 13 Sopron-Bécsidomb. Hungary: 14 Ménfőcsanak. Romania: 15 Ciumeşti. Ireland and southern Britain: 16 Old Croghan (Co. Meath), 17 Clonycavan (Co. Meath), 18 Old Castle (Ogmore) Down (Glamorgan), 19 Ventnor (Isle of Wight), 20 Mill Hill (Deal, Kent), 21 Shouldham (Norfolk), 22 Newnham Croft (Cambridge). Yorkshire: 23 Cowlam, 24 Burton Fleming, 25 Arras, 26 Kirkburn, 27 Danes Graves, 28 Rudston, 29 Burton Fleming, 30 Grimthorpe, 31 Wetwang (Village, Slack), 32 Pocklington. Netherlands: 33 Noordersluis. Spain: 34 Ibiza, 35 Cerro de los Santos

include the ithyphallic pendant from Bourges with its Mont Lassois parallel, the Belgic chariot at Newbridge, and occasional extended inhumations (a Gallic rite) in cemeteries in southeastern England/East Yorkshire that reveal more women than men and a rare penchant for Italian coral. The latter are contemporary, too, with the Damas of coastal Iberia. Ultimately perhaps, the gold-torc depositions of Norfolk might also make more sense in this light (fig. 9; Giles 2012; Pope 2018; Pope 
and Ralston 2011, p. 400). The archaeology at least reveals the further upset at 400 $\mathrm{BC}$ as once again markedly gendered, and this sociopolitical episode, so visible in the texts and archaeology, might now begin to make sense of the linguistics (SimsWilliams 2020, p. 13).

Meanwhile, there were fewer high-status burials in western Germany, and a change from chariot burials to cremations in bronze vessels. Final late Hallstatt burial rites (defined by gold ornaments, drinking vessels, bracelet pair) at Reinheim and Waldalgesheim seem ritualized, feminine, and still reference Etruria (Fig. 9b). At Nebringen, the wealthiest burial was a woman, and the highest strontium values were also with a woman, from Hungary or Romania. These findings illustrate connections between Germany and eastern Europe, with La Tène material culture in Bohemia and Moravia a further indication of feminine wealth (Čižmář 1997; Sankot 1997). Cunliffe (1997) considered Bohemia an origin for the migrations to Italy at $400 \mathrm{BC}$, but the Bohemian material has a $400 \mathrm{BC}$ start date. Similarly, Kruta's (2005, pp. 67, 121) idea that Livy's Boii were from Bohemia seems unlikely, as the Boii reportedly crossed the Poenine Pass, i.e., from the west. A wealth of Bohemian early La Tène material and evidence for subsequent abandonment (e.g., Závist) might, however, support a Bohemian origin for the third century BC "great expedition" to Delphi, although see Kruta (2005, pp. 67, 82-83) for an alternative model. So, while Celts were migrating to North Italy (and north and west), the same process was happening in Germany, with people moving east, marking the final end of late Hallstatt traditions.

\section{Celts, Galatai, and Rome (390/387 BC)}

Polybius records the last group of Celts from Gaul as the Senones from southern Champagne (Kruta 2005, p. 67), where cemeteries reveal desertion of the men. Whether these migrating groups were by then technically still Celts, as of the late Hallstatt period, is a moot point; these late groups moving into North Italy were by now those of the newer northern communities. Certainly, early fourth century Greeks seem to have reserved the term "Celts" for those of North Italy. Another clue comes from Theopompus, whose near-contemporary account used Galatai ( $\Gamma \alpha \lambda \alpha \tau_{\tau} \alpha 1$, Galátai) for those who occupied Rome, as did later Polybius, as distinct from the North Italian Celts. Linguistically, Galatai from Celtic "galos-" means "brave fighter" (Bridgman 2004). Theopompus distinguishing the migrating early La Tène northern communities (e.g., the Senones) from the original late Hallstatt Celts and the north Italian Celts is critically important, finally proving d'Arbois de Jubainville (1875) wrong. Sadly, the writing of Theopompus survives only as fragments in later texts; his Books $42-43$ on the western Celts were lost (Shrimpton 1991, p. 99). In fact, no contemporary accounts on early fourth century BC Celts remain (Table 4). Perhaps Rome sought not to preserve the history of its sacking, perhaps especially as the Galatai, as descendants of the Celts of Gaul, had such a deep heritage of female political authority. It is now clear that the Battle of Allia (387 BC) and the subsequent burning and seven-month occupation of Rome was 
undertaken by the descendants of the Celts, descendants of a potentially matriarchal northern Gaul who, under Vix, had already snubbed the Greeks.

In fact, the only other near-contemporary mention of a Galatai leader, in the late fourth/early third century $\mathrm{BC}$, refers to a woman. The anonymous Tractatus De Mulieribus Claris in Bellos [Women Intelligent and Courageous in Warfare] tells of 14 mostly Early Iron Age women leaders, but including an early fourth century BC Galatai leader, Onomaris (Gera 1997). In the absence of male leadership, Onomaris helped a group suffering from famine and wishing to flee their country by placing their property in common and leading them across the Danube, where she conquered the locals in battle, settled, and led (Gera 1997). A brief redating of the Tractatus is warranted, because of the 14 it is only Onomaris who remains undated. Although two of the women are pre-800 BC, the remainder date to 800-400 BC, giving us a preliminary $400 \mathrm{BC}$ terminus ante quem. An early fourth century $\mathrm{BC}$ date for Onomaris, the final entry, is preferred here, based largely on the use of " $\Gamma \alpha \lambda \alpha$ ó $\tau \omega v . "$ For the catalogue itself, vocabulary, genre, and mode of citation all suggest a late fourth century BC terminus post quem (Gera 1997), while the sources upon which it depends are fifth-third centuries BC. For Gera, two women (Menecles, Xenophilus) push this to $100 \mathrm{BC}$. If so, it is perhaps odd that none of the Tractatus women are in Plutarch's second century AD Mulierum Virtutes (26 notes on outstanding women). This late date is also contradicted by Gera's (1997, p. 126) own argument that the Tractatus was the source for Timaeus' mid-third century BC Dido. As such, a late fourth/early third century BC date seems most appropriate for the writing of the Tractatus; its "women intelligent and courageous in warfare" title very much fits the mood of that time. From Theompompus and the anonymous Tractatus, early fourth century BC Galatai were those on the move.

\section{Confusing the Celts: Plato and Aristotle (350-300 BC)}

Only at the point of the final death of late Hallstatt traditions did Greek writers again mention Celts. At 350 BC, the time of Waldalgesheim's death, Plato (correctly) described Celts as one of six barbarian peoples given to combat and, like Scythian/ Thracian women, to hard drinking. His pupil Aristotle disagreed, emphasizing Celts as a warlike race, laboring that, as such, they were unusually not under the control of their women, preferring instead relations with other men (Pol. 2.6.6) (sic: he seems in fact to be describing Theopompus' early fourth century BC Galatai). The geography of the younger philosophers is also confused: Aristotle by Herodotus' Pyrene (above) while his peer, Heraclides, incorrectly employs the Hyperborean trope for the attack on Rome (see Collis 2003, p. 125). Aristotle ultimately recognized the difference between Celts and Galatai on the basis of their Druids and Semnothei. He also reported Celts (no location, arguably those of North Italy by this point) raising their children with few clothes in a cold climate to aid health, and to fear nothing, neither earthquakes nor waves, but that this, following Plato, was an excess (Tierney 1960). This has always been read as a comment on Celtic foolhardiness; however, it might be read almost as a lament on the relationship between the "civilized" world and their barbarian neighbors in that the bravery of the latter is not of ignorance or 
madness but of spirit, courage, and resolve-as in the Celts who take up arms to resist the waves of the sea, the fruitlessness of resisting the Mediterranean world.

Plato's historical grasp of the Early Iron Age Celts became confused and lost, and his students had a particular problem it seems in understanding the heritage of the North Italian Celts, which is interesting once set in the context of Aristotle's wellstudied misogyny (see Politics). The period toward the end of Aristotle's life (330 BC) sees Celts and Galatai drawn into ridicule by comic poets (Ephippus, Sopater of Paphos), as the archaeology reveals La Tène burials farther east, a manifestation of a defense mechanism, perhaps, against the descendants of those who had razed Rome to the ground. Meanwhile, in contrast to the philosophers, contemporary historians instead reasserted the geography, distinguishing Celts from Iberians and noting a Keltoi nation next to Etruscans at the head of the Adriatic "left behind from the [387 BC] expedition" (Xenophon, Pseudo-Skylax). Ephorus simply repeated Hecataeus in regarding Celts as above Massalia, between Alps and Pyrenees: Celts as Gaul. While an anonymous periplus again placed Celts at the north Pillar. Akin to Plato, Ephorus revealed Keltoi as one of the four great barbarian peoples (Persians to the east, Scythians to the north, Libyans to the south, Celts to the west). More generally, use of "Celts" continued for those of North Italy. A generation after the sacking of Rome, Xenophon again had [presumably North Italian] Celts allied to Syracuse against Thebes in 368 BC. Beyond Theompompus and Xenophon, only later writers detail mid-fourth century BC politics: Polybius reports on a new (357/5 BC) expedition and a first Roman (345 BC) success against the [again presumably North Italian] Celts, while Ptolemy Lagos reports Alexander the Great receiving Celtic emissaries in $335 \mathrm{BC}$ and Polybius reports a $331 \mathrm{BC}$ peace treaty between Gauls and Rome (Table 3).

By the late fourth century BC, matters seem more resolved after Pytheas of Massalia's voyage (310-306 BC), which describes Britain as some days' sail from "Celtica" [Gaul] and distinguishes Keltoi from Germanoi. From Pytheas, Strabo tells us of a small island opposite the Loire mouth, inhabited by Samnite women who practice Bacchic rites (Italian origin) and ritual sacrifices, who sail to the mainland and back for intercourse, and hold an annual temple reroofing ritual in which the first woman to drop her roofing material is ripped limb from limb. Slightly modified by Pomponius Mela, the island is later home to an oracle of a Gallic god, with nine priestesses of remarkable intelligence in a vow of chastity. The Senae (old women) controlled the sea and wind with song, shifted shape, cured the incurable, and predicted the future, western women apparently still resisting the waves of the sea.

\section{Resolving Celts, Galatai, and the Ha-LT Transition}

In 1875, d'Arbois de Jubainville proposed no difference between Keltoi and Galatai, and 20th century archaeologists (Powell, Piggott, Cunliffe, Collis, Kruta) accepted the two as interchangeable, as both terms were used by classical writers. Further, Greek Galatai was proposed as equivalent to Latin Galli as those Celts who migrated south/southeast (Collis 2003, p. 99; Cunliffe 1997), despite Diodorus Siculus specifically noting that Roman writers erroneously conflated the two 
and called them all Gauls (5.32.1). Meanwhile, for Collis (2003, pp. 98-100), early third century BC Hieronymus of Cardia was the first to use Galatai interchangeably with Celts, and only Strabo distinguished between the two. In fact, Hieronymus did distinguish, as did earlier Aristotle regarding Druids/Semnothei-see also his disagreement with Plato, which clearly distinguishes. Further, early fourth century BC Theopompus was the first to use "Galatai" for those who sacked Rome. Of contemporary writers, only Sopater, writer of farce, used the two interchangeably. Archaeologists' grasp of the texts has been our main problem, despite the work of Chadwick. This, alongside a lack of confidence in archaeological method, resulted in deference instead to Caesar.

We are now closer to understanding. Bridgman (2004) argued for Galatai "brave fighters" as a character trait, a nongeographical subgroup of the more general Celts. Cunliffe, too, accepted Celts as a general name, with Galatai specific to those who migrated south (1997, p. 2). Developing this further, I suggest that the fourth century BC distinction (Theompompus, Plato/Aristotle) is primarily temporal: Celts (Early Iron Age central Gaul) and Galatai (La Tène brave fighters), with Celts also retained for those already well established as such in North Italy. Galatai, then, were brave fighters of Celtic descent, those of the shift north. Their martial character, the origins of which is visible in the archaeology of 550/540 BC, took full effect by 450 BC: Galatai as La Tène; La Tène art, the art of warrior ideology. Confusion came from late Hallstatt social traditions that morphed into those of La Tène over time, which explains later classical conflation. A temporal distinction between Celts and Galatai is supported by Strabo (Geog. IV.1.14), who we know used fourth century BC Ephorus. This suggests Keltai $(\mathrm{K} \dot{\varepsilon} \lambda \tau \alpha \mathrm{l})$ as the oldest given name (i.e., seventh century BC). Collis (2003) reads this as Keltoi (general) receiving their name after a small group named Keltai (presumably those inland from Massalia, after Hecataeus). Linguistically, however, Keltai seems to derive from the Latin Celtae, perhaps supporting a later origin for the name in line with the first century BC texts (Strabo, Posidonius) in which it is first given (B. Cartlidge, personal communication 2019). Nevertheless, the oral history that Strabo communicates may still be valid.

The important thing that Strabo recorded seems to be that the name "Keltoi" was Celtic in origin, as also reported by Hieronymous of Cardia in the third century $\mathrm{BC}$. The term first appears in fragments from the anonymous Massilliot periplus of $600 \mathrm{BC}$; it also was used by historian/geographer Hecateaus and traveler Himilco of Carthage at around $500 \mathrm{BC}$. The name was used for those encountered in Early Iron Age inland Gaul, who were in reality a whole series of valley-based, apparently matrifocal groups. In Greek, the prefix kel- is of noisiness/shouting/exhortation, dark/gloominess, traveling, which suggest Keltoi as a nickname, almost "the shouty ones" in the vein of the Boii (the terrible ones) and the Aedui (the fiery ones). The name sits within an apparently Celtic naming tradition, yet the written word as received is Greek, and so seems a mixing of the two traditions, as in Aristotle's origin tale for Massalia.

The name "Galatai" ( $\Gamma \alpha \lambda \alpha \dot{\alpha} \alpha \mathrm{l})$ is present by the fourth/third centuries BC (Theompompus, Aristotle) (cf. Collis 2003, p. 99; Kruta 2005, p. 15). Its root "galos," brave fighter, was a new name for a now La Tène north. It is often taken to refer to Gaul, but the two are not mutually exclusive (contra Cunliffe 1997, p. 2). From third 
century BC Hieronymus of Cardia (Pausanius 1.3.5), the Galatai, originally Celts, inhabited northern Europe (with "Galatas" asserted as a late term), while third century BC Timaeus called northern Europe Galatia (Dinan 1911, p. 145). The concept of Gaul is thus later than the first Galatai, who were those of Celtic descent and specifically northern. Confusion also exists between fourth century BC Galatai (northern Europe) and Galatae (eastern Europe). Both were ultimately of Celtic origin and only later conflated as one people.

By the fourth century BC, then, La Tène Galatai (brave fighters) had morphed out of sixth/fifth century BC Keltoi (central Gaul), who were named after a seventh century BC group inland of Massalia. Diodorus Siculus, who, like Strabo, used earlier Ephorus, gives further geographical distinction between Celts and Galatai, with the latter above Celtica, along the ocean and Black Forest (source of Danube) east to Scythia (5.32.1, quoting Posidonius). So, Celts were of central Gaul, while Galatai were more northern/eastern (i.e., our northern La Tène cemeteries of Marne, Rhineland, Bohemia); this is the "shift north" identified in the archaeology. Further, Diodorus distinguished between Galates (Gauls) and Galatai, linking Galates with Alesia (Gaul) and placing Galatai farther north beyond the Rhine (5.24-25). In summary, Celts were well established and from central Gaul; Galatai were new (La Tène brave fighters) and located farther north and east.

Plato's 350 BC "women who drink" (i.e., Vix, and Waldalgesheim as Plato's direct contemporary) is a recording of the embers of Celts and late Hallstatt traditions, who at their late fifth century BC zenith prized alcohol and challenged the Greeks, while Aristotle in the 330s BC described instead the masculine brave fighters of the early fourth century BC as fearless, warlike, and homosexual. There is a time lag here, as if Greek knowledge of these other peoples is already a generation or two old. Between Herodotus/Plato (435-350 BC) and Aristotle/Ephorus (350-330 BC), Greek knowledge of the Celts had shifted, from those of Gaul/Württemberg (late Hallstatt drinking traditions) to the more masculine/martial traditions of La Tène (Galatai). While Aristotle arguably sought to write Celtic women out of history, following the sacking of Rome by those of a matrifocal Champagne culture, Strabo (Geog. 4.1.14) instead seems to gender Gaul female (Collis 2003, p. 99). The sequenced archaeology agrees with Strabo's text on Belgic Gaul (Geog. 4.4.3): "But as for their custom relating to the men and the women (I mean the fact that their tasks have been exchanged, in a manner opposite to what obtains among us), it is one which they share in common with many other barbarian peoples."

\section{Discussion: Lost in the Mists of Time?}

Having employed chronologically sequenced archaeological data and contemporary classical texts, we find that the original use of "Celts" refers to matrifocal Early Iron Age groups in central Gaul, as Caesar ( $D B G$ 1.1) almost had it. Archaeology, linguistics, and aDNA studies all now point to the same conclusion, that Celts had Bronze Age origins; they did not "arrive" from anywhere else, with small groups settling in North Italy by the seventh century BC (Golasecca, Adriatic). The evidence confirms that Celts were not initially of Britain or Spain (beyond Tartessos), 
each an area where Celtic language developed later (fourth and late third centuries $\mathrm{BC}$, respectively). We might argue, tentatively, for some survival of Celtic traditions in the archaeology of the Atlantic west, after $400 \mathrm{BC}$, something that may help expand our understanding of Celtic identity through time (see also Sims-Williams 2020, p. 13; cf. James 1999).

Our historical Iron Age Celts were distinct from late Hallstatt archaeological traditions (as centered on Austria/Germany; Fig. 4), meaning we can finally reject Duval's (1977) late Hallstatt=early Celt hypothesis, although those of eastern Gaul did adopt late Hallstatt traditions from Württemberg. Some Celts are recorded as having moved to the Danube source - the Seine-Danube corridor of the archaeology - with potential lineages now identified between the two areas that reveal significant cultural overlap but also marked social differences, not the least of which regard gendered social structures (Pope 2018). At 600 BC, the western Mediterranean had many culturally different yet crucially intermingling groups: Tartessians (Phoenician influence), Ligurians (coastal groups), Massaliots (Phocaeans, Celts), Etruscans (North Italy), variant late Hallstatt traditions inland (Austria, Bavaria, Württemberg), Celts (central Gaul), and Celts (North Italy). Each is a shorthand, a name applied by Greeks, Romans, archaeologists, and linguists to categorize and simplify a yet more complex social reality. The archaeology demonstrates that each region actually comprised numerous, much smaller, valley-based social groups. Initially, texts and archaeology revealed Celts to be friendly with Phocaeans, Etruscans, and their likely cousins in Württemberg; they even moved to be in direct proximity (Narbo, North Italy, Heuneburg). Celts then evolved socially into their descendants: the Galatai, the brave fighters of early La Tène.

A period of major political drama at $550 / 540 \mathrm{BC}$, along with population growth (Fig. 6), corresponds with a first move out of the Seine-Danube corridor, as Celts continued to move to North Italy. The root of the upset was that central Gaul apparently preferred more feminine Etruria while Württemberg preferred more masculine Greece. The archaeology reveals unrest to the north and east of the old Hallstatt heartland. In Württemberg, some women were buried with daggers/spears; in Ha D1-established patrifocal Bavaria, men were buried with spears. At the same time, new communities were established in the north (men with spears in Rhineland and some women with daggers in Champagne). As such, the initial formation of a new La Tène social order may have originated at 550/540 BC, potentially linked socially to the 540/530 BC fire at the Heuneburg. At a time of wider anti-Greek feeling in the Mediterranean, some in Württemberg seem to have been unhappy with golden-shoed Hochdorf and his Greek alliance/links: the disproportionate deposition of female wealth in Württemberg and Bavaria reveals fractured communities that disowned their past. Celts seem to have been less affected than their southern German cousins at this time. A generation later, Vix's grave restated a Celtic-Italic identity, influenced by deep North Italian links, perhaps around Breton tin. As Tierney (1960) had it, a move against materialism in fourth century BC Greece (Plato, Theopompus, Ephorus) may then have begun at 550/540 BC in the west with the active rejection of Greek-derived wealth, as typified by Hochdorf's golden shoes, in a move to an austere, egalitarian, and equitable north and west (Fig. 9b). As some in 
late Hallstatt Germany actively parted company with Greek-inspired values, some Celts moved to join those nearer the Etruscans.

The early Greek texts do not see Celts as a pan-European culture (contra Hornblower et al. 2012). Fifth century BC Greek voyagers place Celts, at their height, in central/northern Gaul, from the Rhine mouth to the Danube source, alongside peak engagement with late Hallstatt traditions. At $500 \mathrm{BC}$, Massaliot trade to the north ended (Kruta 2005, p. 52) as Celts, under Vix, instead established their own trading posts on the Mediterranean, enabling direct long-distance contact: Narbo (midway between Massalia and Emporion), southwestern Spain (near Gadir), and especially settlement in North Italy, next to Etruria. In discussing the long relationship between Gaul and North Italy, which resulted in the early fourth century BC migrations, Kruta (2005, p. 70) talks of acculturation and assimilation, a "back and forth" of Celts across the Alps. Collis (2003, pp. 182, 192), too, has continuous contact, with Celts entwined with Etruscan culture. The Celtic province in North Italy exercised a "profound and durable influence" on the Celts of Gaul (Kruta 2005, p. 75; Rolley 2003, fig. 245), it was this long-term to-and-fro contact, and presumably deep kinship, between the two regions that resulted in the political decision making of Vix.

A generation after Vix's potential descendant Lavau died, came more political upset. In 450 BC, there was the "shift north" (Fig. 8) and a decline of late Hallstatt traditions in Germany: the Heuneburg was abandoned, Greek trade ended, and final late Hallstatt graves appear ritualized (Reinheim, Glauberg). Alongside this was more disproportionate deposition of female wealth in the graves of the old Hallstatt heartland (Austria, into Switzerland) and ritual deposition also at the type site of La Tène itself. The lead-up to the Hallstatt-La Téne transition is perhaps best captured in the sequence of the wealthiest burials in the Hallstatt-Dürrnberg salt community: seventh century BC (G507, male/female couple), sixth century BC (G505, female), and fifth century BC (T44/2, male). Meanwhile Galatai traditions grew; a northern crescent formed around a declining Württemberg core (Fig. 11), with new groups in Aisne-Marne and the upper Seine basin (430/425 BC), and a now well-established Champagne flourished (425-400 BC). These newer communities were again markedly martial, as people again seemingly fought their way out of the old Hallstatt order, leading to generations of subsequent warrior identities. The archaeology now suggests several influential factors-Mediterranean politics, traditional allegiances, tin, reactions against greed, gender politics - that augment Cunliffe's (1997, p. 74) overpopulation (taken from Livy but perhaps supported now in the archaeology; Fig. 6).

The traditional date for the Ha-LT transition is $450 \mathrm{BC}$. What we have discovered, however, is that a new social form was already evolving three generations before the other died, as was first identified in German chronology of the 1970s (see Collis 2003, pp. 167-168). The question now is whether this 550/450 BC disjuncture in the German/French archaeology might be an artifact of that early German chronology, with now a good time to revisit the relative chronology of the two regions. If the disjuncture holds, then the transition was a process, a slow identity shift that took place in full across two centuries (550-350 BC), with the origins of a martial La Tène identity first in Rhineland at $550 \mathrm{BC}$, a $450 \mathrm{BC}$ floruit marked by the cessation of Greek trade, and the survival of late Hallstatt ritualized burial traditions to $350 \mathrm{BC}$ 


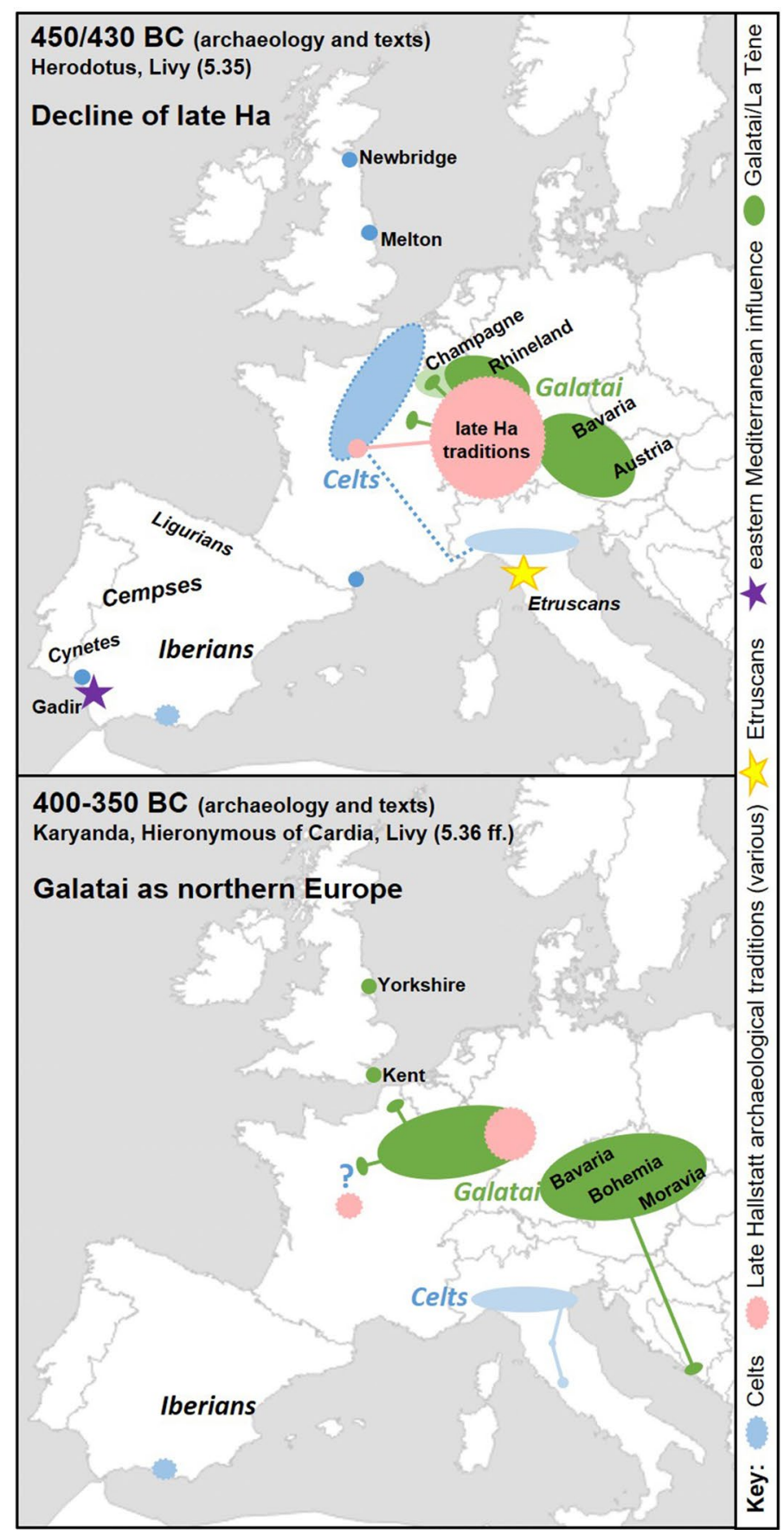

Fig. 11 Temporal maps (450-350 BC): integration of evidence from texts and archaeology (note: the shapes on the map do not represent culture groups; they are artifacts of archaeological and textual data only) 
(Waldalgesheim). The transition from one social order to another took place over several generations and varied markedly in character between regions.

The transition is not from Hallstatt to La Tène but from late Hallstatt/Celts to La Tène/Galatai. Those of the La Tène period in northern Europe became known to the Greeks as Galatai/brave fighters, while the already well-established Celts of North Italy retained the older name. Galatai were notably more egalitarian and jettisoned the wealth of Hallstatt traditions out of Austria (salt) and Württemberg (Greece). Yet, critically, this more masculine, martial society was not patrifocal (Pope 2018). Historically, it was only at the end of the process (late fourth century $\mathrm{BC}$ ) that Aristotle began to identify Galatai as different from the Celts of old, after his teacher Plato had begun to record the latter, following the attack on Rome, as mentioned by Aristotle's peer, Heraclides Ponticus. Aristotle described the Galatai as fearless, homosexual, and not ruled by their women; the masculine nature of the migrating groups is now verified in the archaeology.

By 400 BC, depopulation of the newer settlements (Rhineland, Marne, Champagne, Bercy, south Bohemia) is contemporary with apparent population increase farther east (Bohemia, Moravia), west (Bourges, Britain), and south to Italy. Arnold's (1995b) argument that male absence led to female authority does not work here, as female wealth increased in advance of masculine out-migration at $400 \mathrm{BC}$, a trend that instead reflected the deep history of matrifocal social forms. Over the course of a century a different but connected Würrtemberg/Burgundy had effectively split in two: a new, egalitarian, and austere north, and a traditional, hierarchical, and showy south. At $400 \mathrm{BC}$, the long contact between northwest Europe and North Italy largely ended (Arnold 1995a), although it may have lasted to $350 \mathrm{BC}$ at Waldalgesheim and to 300 BC farther west in the Paris basin. Meanwhile in Britain, the few instances of Italian coral, or its substitutes, in brooch decoration feel old, inherited.

Current interpretation, then, is that the Celts of Gaul did not survive as such beyond $450 \mathrm{BC}$, except as those who had long identified as Celts in North Italy and perhaps as a more fragmented identity farther west (western France, Spain, coastal Britain). In the fourth century BC, a shift took place from decorative Early Iron Age daggers to swords, implying a greater degree of active combat (with swords practically utilitarian by La Tène B) as political tensions replaced contact/exchange, although Britain seems to have been once again different. Livy's late-stage migrations to North Italy also resulted in tension and, ultimately, the sacking and occupation of Rome in $387 \mathrm{BC}$ by the descendants of the Celts.

The story of the Iron Age western Mediterranean, then, is that Württemberg, presumably via the success of the Austrian salt trade, became increasingly fond of (masculine) Greece while Celts (Gaul) preferred (feminine) Etruria. The origins of the new La Tène social order were partly influenced by wider Mediterranean politics; they were coeval with Hochdorf's authority in Württemberg (550/540 BC), which resulted in an episode of what seems to have been relatively violent out-migrations (to the north and east). A new martial, but ultimately equitable, La Tène period of brave fighters, fought their way out of old late Hallstatt social values and instead established settlements farther north while Hallstatt traditions continued in the old heartland. This 550/540 BC rebellion seems to have been largely led by women 
in the west (Württemberg, Champagne) and men in the east (Rhineland, Bavaria). A less-violent response in Gaul seems the result perhaps of the political savvy of Vix, whose burial assemblage actively signaled an anti-Greek political mood. These northern communities were subsequently joined by more (men) at 450/430 BC. Key here, alongside martial masculinity, was the (rapid) deposition of women's late Hallstatt wealth. Between 450 and $350 \mathrm{BC}$, after contact with Greece was dropped, the old feminine late Hallstatt social system, now ritualized, was in very active decline.

The archaeology suggests that these fairly liberal Early Iron Age societies were associated with small episodes of predominantly, although not exclusively, masculine out-migration (Pope 2018). The gender of this activity is not so clearly masculine in Gaul, however, as it is farther east in Germany, until after $450 \mathrm{BC}$. The display of a martial heritage/identity at $450 \mathrm{BC}$ was perhaps referencing the initial period of unrest at 550/540 BC and also relating to their becoming known as the brave fighters. The new La Tène social order is nevertheless considered relatively egalitarian/equitable in recent archaeological analyses of burial datasets out of France and Britain (Evans 2004; Giles 2012; Pope and Ralston 2011; Trémeaud 2019). The irony, of course, is that it was the Roman fear of the Galatai who sacked Rome, with their martial prowess and sexual freedom, and as descendants of the Celts, with their deep history of matrifocal society and their political move against the Greeks, that may be partly what led, ultimately, to the backlash that was the Roman Empire.

\section{Conclusions}

By combining archaeology and contemporary texts, the "impossible" origin of the historical Celts that has eluded resolution for over a century is further resolved. The name "Keltoi" is a merging of Celtic naming and Greek writing. Celts had Bronze Age origins in Gaul, with early groups settling in North Italy and at Spain's north pillar (as supported now in the linguistics) and developing connections east to the Heuneburg. These Celts of central Gaul were widely traveled and connected; they looked north to tin and south to the Mediterranean. They were at their height in the late sixth century BC, under Vix, who, at a time of wider anti-Greek feeling, snubbed Greece for Etruria, with Celtic outposts established on the Mediterranean coast to cut out Phocaean middlemen. During the decline of the late Hallstatt social order (550-450 BC), some Celts abandoned late Hallstatt traditions in favor of joining the more austere brave fighters of La Tène northern Europe, and others moved to North Italy where they retained their Celtic identity. By 400 BC, however, these northern early La Tène communities had fragmented again, our "Celtic migrations," with some (men) moving to North Italy and ultimately encountering Rome, while others (women) moved west, as perhaps now fits the Celtic linguistics evidence from the third century BC.

As defined in the early classical texts, these groups known as Celts never equated fully to late Hallstatt archaeological traditions (contra Duval 1977) nor to those of La Tène (contra Cunliffe 1997). In fact, "Celts" as a historical label does not map neatly onto any archaeological tradition; it overlaps with late Hallstatt traditions in 
northeast France and less ostentatious archaeologies farther west. This very overlap is perhaps the cause of much of the political strife. Nor did the name "Celt" ever equate to all of Gaul, let alone all of Europe. It was instead a label for less than a quarter of Gaul and more akin to Caesar's first century BC Celtic Gaul. Yet even this remains a gross oversimplification. Iron Age settlement was within valleys and at points on coastlines but did not cover whole regions. The name "Celt" was, and remains, a categorization by Greeks, Romans, and archaeologists for various smallscale Early Iron Age groups. Our error has been trying to force that label to fit the archaeology/linguistics/state, none of which is about Iron Age people. "Celts" was only ever a shorthand. Attempting to define Celts as a cultural entity is nonsensical; these groups did not represent an ethnicity. Instead, we know from the archaeology that we are dealing with a nickname for a multiplicity of prehistoric groups. It is important to make clear that regional archaeological traditions do not perform the same role as early 20th century "cultures," tied as ethnicity to large-scale linguistics spreads. Regional archaeological traditions are not bounded social entities but instead placeholders, as we continue to refine our method on the scale of past social groups and the time-depth of social change by reducing the scale of our analysis ever further.

Having improved our understanding of the historical Celts, we find that the archaeology, texts, and linguistics finally converge, so too the aDNA. Celtic language is now believed to have Bronze Age roots in Gaul. Early Celtic (Venetic, Lepontic) is found in North Italy, with fragments now claimed also in southwestern Spain: each might now receive a cautious seventh century BC date. The growth of "Celtic proper"- a phenomenon of the Celtic migrations (actually the descendants of the Celts) - is seen farther west in the third century BC (Spain, Britain) as well as east to Galatia (Cunliffe and Koch 2019; Sims-Williams 2020). Important to this work is an understanding that people, in a myriad of social networks communicate, travel, and integrate, meaning that traditions ultimately shift, typically over centuries, and societies change-Late Hallstatt society lasted 200 years, Jogassian 150 years. The past is a continuous coming and going of individuals and small groups, that is how metal and burial rites shifted east as ceramics shifted west (Collis 2003, p. 188). Movement was small-scale over time (Cunnington 1923). Even the migrations to North Italy took place over 200 years. Social transitions typically take time; the demise of Hallstatt traditions took three to four generations, and Greek texts display a 60-year time lag in knowledge.

The historian d'Arbois de Jubainville (1875), who sought to conflate Celts, Galatai, and Gaul, has been remarkably unhelpful all these years, while archaeologist Bertrand (1876), who sought to marry texts and archaeology with applied dating methods and saw evidence for social distinction, i.e., smaller social units, was right. The long game of critically applied scientific method will ultimately create a better social narrative, and so a better grasp of humanity, than rapid, historicist generalisms. Similarly, if we seek to study past societies without actively considering the women along with their men, then we will only ever half-understand those societies. The latter is something that is especially relevant to the study of the Celts, and it may help explain why we have struggled with them for so long. What remains now 
is to further refine our chronologies and our social understanding of regional/local Iron Age archaeologies.

Supplementary Information The online version contains supplementary material available at https://doi. org/10.1007/s10814-021-09157-1.

Acknowledgments I gratefully thank Professor John Collis and several anonymous reviewers for debate and learning. Thanks also go to Dr. Ben Cartlidge (University of Oxford) for translations and advice on linguistics and texts, to Dr. Eleni Asouti (University of Liverpool) for advice and support, and to Dr. Susanne Hakenbeck (University of Cambridge), Professor Dan Hicks (University of Oxford), Dr. Lesley McFadyen (Birkbeck, University of London), and Professor David Wengrow (University College London) for developing my thinking over the years on how best to do archaeology.

Open Access This article is licensed under a Creative Commons Attribution 4.0 International License, which permits use, sharing, adaptation, distribution and reproduction in any medium or format, as long as you give appropriate credit to the original author(s) and the source, provide a link to the Creative Commons licence, and indicate if changes were made. The images or other third party material in this article are included in the article's Creative Commons licence, unless indicated otherwise in a credit line to the material. If material is not included in the article's Creative Commons licence and your intended use is not permitted by statutory regulation or exceeds the permitted use, you will need to obtain permission directly from the copyright holder. To view a copy of this licence, visit http://creativecommons.org/licen ses/by/4.0/.

\section{References Cited}

Antcil, M. (2019). Assessing regional dental affinities among Iron Age populations in Austria and their associations with the Celts. Presentation at IARSS Cardiff, based on unpublished Ph.D. thesis, John Moores University, Liverpool.

Arnold, B. (1991). The deposed princess of Vix: The need for an engendered European prehistory. In Walde, D., and Willows, N. D. (eds.), The Archaeology of Gender: Proceedings of the Second Annual Chacmool Conference, University of Calgary, Calgary, pp. 361-374.

Arnold, B. (1995a). The material culture of social structure: Rank and status in Early Iron Age Europe. In Arnold, B., and Blair Gibson, D. (eds.), Celtic Chiefdom, Celtic State: The Evolution of Complex Social Systems in Prehistoric Europe, Cambridge University Press, Cambridge, pp. 43-52.

Arnold, B. (1995b). 'Honorary males' or women of substance? Gender, status and power in Iron Age Europe. Journal of European Archaeology 3: 151-168.

Arnold, B. (2006). Gender and archaeological mortuary analysis. In Nelson, S. M. (ed.), Handbook of Gender Archaeology, AltaMira, Lanham, MD, pp. 137-170.

Arnold, B. (2012). Gender, temporalities, and periodization in Early Iron Age west-central Europe. Social Science History 36: 85-112.

Arnold, B., and Blair Gibson, D. (eds.) (1995). Celtic Chiefdom, Celtic State: The Evolution of Complex Social Systems in Prehistoric Europe, Cambridge University Press, Cambridge.

Bertrand, A. (1876). Archéologie celtique et cauloise: Mémoires et documents relatifs au premiers temps de notre histoire nationale, Didier, Paris.

Bickle, P. (2019). Thinking gender differently: New approaches to identity difference in the central European Neolithic. Cambridge Archaeological Journal 30: 1-19.

Binford, L. (1967). Smudge pits and hide smoking: The use of analogy in archaeological reasoning. American Antiquity 32: 1-12.

Booth, T. (2019). A stranger in a strange land: A perspective on archaeological responses to the palaeogenetic revolution from an archaeologist working amongst palaeogeneticists. World Archaeology 51: 586-601.

Bowden, M., and McOmish, D. (1987). The required barrier. Scottish Archaeological Review 4: 76-84. 
Bridgman, T. P. (2004). Keltoi, Galatai, Galli: Were they all one people? Harvard Celtic Colloquium 25: $155-162$.

Brück, J. 1999. Houses, lifecycles and deposition on Middle Bronze Age settlements in southern England. Proceedings of the Prehistoric Society 65: 145-166.

Brück, J. (2004). Material metaphors: The relational construction of identity in Early Bronze Age burials in Ireland and Britain. Journal of Social Archaeology 4: 307-333.

Brück, J. (2021). Kinship: Politics and practice. Antiquity 95: 1-3.

Brun, P. (1988). Les 'résidences princières' comme centres territoriaux: Éléments de verification. In Les princes celtes et la méditerranée, Rencontres de l'École du Louvre, Paris, pp. 128-143.

Brun, P. (1994). From Hallstatt to La Tène period in the perspective of the Mediterranean world economy. In Kristiansen, K., and Jensen, J. (eds.), Europe in the First Millennium BC, Collis, Sheffield, pp. 57-65.

Brun, P. (1995). From chiefdom to state organization in Celtic Europe. In Arnold, B., and Blair Gibson, D. (eds.), Celtic Chiefdom, Celtic State: The Evolution of Complex Social Systems in Prehistoric Europe, Cambridge University Press, Cambridge, pp. 13-25.

Brun, P. (2018). Funerary practices. In Haselgrove, C., Rebay-Salisbury, K., and Wells, P. S. (eds.), The Oxford Handbook of the European Iron Age, Oxford University Press, Oxford (Oxford Handbooks Online) https://doi.org/10.1093/oxfordhb/9780199696826.013.8

Brunel, S., Bennett, E. A., Cardin, L., Garraud, D., Barrand Emam, H., Beylier, A., et al. (2020). Ancient genomes from present-day France unveil 7,000 years of its demographic history. Proceedings of the National Academy of Sciences 177: 12791-12798.

Büchsenseschütz, O. (1995). The significance of major settlements in European Iron Age society. In Arnold, B., and Blair Gibson, D. (eds.), Celtic Chiefdom, Celtic State: The Evolution of Complex Social Systems in Prehistoric Europe, Cambridge University Press, Cambridge, pp. 53-63.

Büchsenseschütz, O., and Mordant, C. (eds.) (2005). Architectures protohistoriques en Europe occidentale du Neolithique Final a l'âge de Fer, Comité des Travaux Historiques et Scientifiques, Paris.

Butler, J. (1990). Gender Trouble, Routledge, London.

Butler, J. (2020). Interview with Judith Butler. New Statesman 22/09/20.

Cardale Babington, C. (1881). Address delivered at the meeting of the Cambrian Archaeological Association, Church Stretton, Aug. 1st, 1881. Cambrian Archaeological Association, Church Stretton.

Carsten, J. (ed.) (2003). Cultures of Relatedness: New Approaches to the Study of Kinship, Cambridge University Press, Cambridge.

Chadwick, N. (1964). Celtic Britain, Thames and Hudson, London.

Chadwick, N. (1971). The Celts, Pelican, London.

Champion, S. (1994). Regional studies: A question of scale. In Kristiansen, K., and Jensen, J. (eds.), Europe in the First Millennium BC, Collis, Sheffield, pp. 145-150.

Childe, V. G. (1929). The Danube in Prehistory, Clarendon, Oxford.

Čižmár, M. (1997). The Celtic population of Moravia in the fourth century BC. In Moscati, S., Frey, O.-H., Kruta, V., Raftery, B., and Szabó, M. (eds.), The Celts, 2nd ed., Rizzoli, New York, pp. 297-301.

Clark, G. (1966). The invasion hypothesis in British archaeology. Antiquity 40: 172-189.

Clarke, A., and Haraway, D. (2018). Making Kin not Population: Reconceiving Generations, Prickly Paradigm Press, Chicago.

Clarke, D. L. (1968). Analytical Archaeology, Methuen, London.

Clarke, D. L. (1972). A provisional model of an Iron Age society. In Clarke, D. L. (ed.), Models in Archaeology, Methuen, London, pp. 801-870.

Collis, J. R. (1984). The European Iron Age, Batsford, London.

Collis, J. R. (1985). Review of Danebury: An Iron Age Hillfort in Hampshire, Vols. 1 and 2, by B. W. Cunliffe. Proceedings of the Prehistoric Society 51: 348-349.

Collis, J. R. (1986). Adieu Hallstatt! Adieu La Tène! In Duval, A., and Gomez de Soto, J. (eds.), Actes du VIIIe Colloque sur Ies Ages du Fer en France non-Mediterranéenne, Angoulême, 1984, Aquitania Supplément 1, Fédération Aquitania, Bordeaux, pp. 327-330.

Collis, J. R. (1994). Reconstructing Iron Age society. In Kristiansen, K., and Jensen, J. (eds.), Europe in the First Millennium BC, Collis, Sheffield, pp. 31-39. 
Collis, J. R. (1995). States without centres? The middle La Tène period in temperate Europe. In Arnold, B., and Blair Gibson, D. (eds.), Celtic Chiefdom, Celtic State: The Evolution of Complex Social Systems in Prehistoric Europe, Cambridge University Press, Cambridge, pp. 75-80.

Collis, J. R. (1996). The origin and the spread of the Celts. Studia Celtica 30: 17-34.

Collis, J. R. (1997). Celtic myths. Antiquity 71: 195-201.

Collis, J. R. (2003). The Celts: Origins, Myths and Inventions, Tempus, Stroud.

Collis, J. R. (2008). The Celts as 'grand narrative.' In Jones, A. (ed.), Prehistoric Europe: Theory and Practice, Blackwell, Oxford, pp. 35-53.

Collis, J. R. (2009a). Die konstruktion von chronologien. In Karl, R., and Leskovar, J. (eds.), Interpretierte Eisenzeiten 3, Oberösterreichische Landesmuseen, Linz, pp. 373-420.

Collis, J. R. (2009b). Déchelette's contribution to Iron Age studies: Theory and practice. Anabases 9: $239-247$.

Collis, J. R. (2011). "Reconstructing Iron Age society” revisited. In Moore, T., and Armada, X.-L. (eds.), Western Europe in the First Millennium BC: Crossing the Divide, Oxford University Press, Oxford, pp. 223-241.

Collis, J. R. (2017). Celts ancient and modern: Recent controversies in Celtic studies. Studia Celtica Fennica 14: 58-71.

Collis, J. R. (2019). Reconstructing Iron Age societies: What went wrong. In Currás, B. X., and Sastre, I. (eds.), Alternative Iron Ages: Social Theory from Archaeological Analysis, Routledge, London, pp. 95-108.

Collis, J. R., and Karl, R. (2018). Politics and power. In Wells, P. S., Rebay-Salisbury, K., and Haselgrove, C. (eds.), The Oxford Handbook of the European Iron Age, Oxford University Press, Oxford (Oxford Handbooks Online) https://doi.org/10.1093/oxfordhb/9780199696826.013.11

Conkey, M. W., and Spector, J. (1984). Archaeology and the study of gender. Advances in Archaeological Method and Theory 7: 1-29.

Cripps, L. (2007). Re-situating the later Iron Age in Cornwall and Devon: New perspectives form the settlement record. In Haselgrove, C., and Moore, T. (eds.), The Later Iron Age in Britain and Beyond, Oxbow, Oxford, pp. 156-172.

Crumley, C. (1995a). Building an historical ecology of Gaulish politics. In Arnold, B., and Blair Gibson, D. (eds.), Celtic Chiefdom, Celtic State: The Evolution of Complex Social Systems in Prehistoric Europe, Cambridge University Press, Cambridge, pp. 26-33.

Crumley, C. (1995b). Heterarchy and the analysis of complex societies. In Enhrenreich, R., Crumley, C., and Levy, J. (eds.), Heterarchy and the Analysis of Complex Societies, Archeological Papers No. 6, American Anthropological Association, Arlington, VA, pp. 1-5.

Cunliffe, B. W. (1974). Iron Age Communities in Britain, 1st ed., Routledge, London.

Cunliffe, B. W. (1983). Danebury: Anatomy of an Iron Age Hillfort, Batsford, London.

Cunliffe, B. W. (1984). Iron Age Wessex: Continuity and change. In Cunliffe, B., and Miles, D. (eds.), Aspects of the Iron Age in Central Southern Britain, Committee for Archaeology Monograph 13, Oxford University, Oxford, pp. 12-44.

Cunliffe, B. W. (1988). Greeks, Romans and Barbarians: Spheres of Interaction, Batsford, London.

Cunliffe, B. W. (1991). Iron Age Communities in Britain, 3rd ed., Routledge, London.

Cunliffe, B. W. (1997). The Ancient Celts, Penguin, London.

Cunliffe, B. W. (2012). Celticization from the west: The contribution of archaeology. In Cunliffe, B., and Koch, J. T. (eds.), Celtic from the West: Alternative Perspectives from Archaeology, Language and Literature, Oxbow, Oxford, pp. 13-38.

Cunliffe, B. W. (2013). The Celts - Where next. In Cunliffe, B. W., and Koch, J. T. (eds.), Celtic from the West 2: Rethinking the Bronze Age and the Arrival of Indo-European in Atlantic Europe, Oxbow, Oxford, pp. 219-223.

Cunliffe, B. W. (2019a). Setting the scene. In Cunliffe, B., and Koch, J. T. (eds.), Exploring Celtic Origins: New Ways Forward in Archaeology, Linguistics, and Genetics, Oxbow, Oxford, pp. 1-17.

Cunliffe, B. W. (2019b). The Scythians: Nomad Warriors of the Steppe, Oxford University Press, Oxford.

Cunliffe, B. W., and Koch, J. T. (eds.) (2012). Celtic from the West: Alternative Perspectives from Archaeology, Language and Literature, Oxbow, Oxford.

Cunliffe, B. W., and Koch, J. T. (eds.) (2013). Celtic from the West 2: Rethinking the Bronze Age and the Arrival of Indo-European in Atlantic Europe, Oxbow, Oxford.

Cunliffe, B. W., and Koch, J. T. (2016). Introduction. In Cunliffe, B. W., Koch, J. T., Cleary, K., and Gibson, C. D. (eds.), Celtic from the West 3: Atlantic Europe in the Metal Ages: Questions of Shared Language, Oxbow, Oxford, pp. 1-17. 
Cunliffe, B. W., and Koch, J. T. (eds.) (2019). Exploring Celtic Origins: New Ways Forward in Archaeology, Linguistics, and Genetics, Oxbow, Oxford.

Cunliffe, B. W., and Rowley, T. (eds.) (1976). Oppida: The Beginnings of Urbanisation in Barbarian Europe, British Archaeological Reports, Oxford.

Cunnington, M. E. (1923). The Early Iron Age Inhabited Site at All Cannings Cross, Wiltshire, Simpson, Devizes.

Cunnington, M. E. (1932). Was there a second Belgic invasion (represented by bead-rim pottery)? The Antiquaries Journal 12: 27-34.

Currás, B. X., and Sastre, I. (2019a). Segmentary societies: A theoretical approach from European Iron Age archaeology. In Currás, B. X., and Sastre, I. (eds.), Alternative Iron Ages: Social Theory from Archaeological Analysis, Routledge, London, pp. 127-148.

Currás B. X., and Sastre, I. (2019b). Egalitarianism and resistance: A theoretical proposal for Iron Age northwestern Iberian archaeology. Anthropological Theory 20: 300-329.

d'Arbois de Jubainville, H. (1875). Les celtes, les galates, les gaulois. Revues Archéologique 2: 1-15.

de Beauvoir, S. (1949) The Second Sex, Harmondsworth, Middlesex.

Déchelette, J. (1913). Manuel d'archéologie préhistorique et celtique, T. II.2, Premier âge du Fer ou époque de Hallstatt, Picard, Paris.

Diepeveen-Jansen, M. (2007). Early La Tène burial practices and social (re)construction in the MarneMoselle region. In Haselgrove, C., and Pope, R. (eds.), The Earlier Iron Age in Britain and the Near Continent, Oxbow, Oxford, pp. 374-389.

Dillon, M., and Chadwick, N. K. (1967). The Celtic Realms, Weidenfeld and Nicolson, London.

Dinan, W. (1911). Monumenta historica celtica: Notices of the Celts in the Writings of the Greek and Latin Authors from the Tenth Century BC to the Fifth Century AD, Vols. 1-3, Nutt, London.

Dobesch, G. (1997). Ancient literary sources. In Moscati, S., Frey, O.-H., Kruta, V., Raftery, B., and Szabó, M. (eds.), The Celts, 2nd ed., Rizzoli, New York, pp. 30-38.

Duval, P.-M. (1977). Les celtes, Éditions Gallimard, Paris.

Duval, P.-M. (1997). Celtic art. In Moscati, S., Frey, O.-H., Kruta, V., Raftery, B., and Szabó, M. (eds.), The Celts, 2nd ed., Rizzoli, New York, pp. 19-21.

Eggert, M. K. H. (1988). Riesentumuli und Sozialorganisation: Vergleichende Betrachtungen zu den sogenannten "Fürstengrabhügeln" der Späten Hallstattzeit. Archäologisches Korrespondenzblatt 18: 263-274.

Ehrenberg, M. (1989). Women in Prehistory, British Museum Press, London.

Evans, T. L. (2004). Quantitative Identities: A Statistical Summary and Analysis of Iron Age Cemeteries in North-Eastern France 600-130 BC, BAR International Series 1226, Archaeopress, Oxford.

Feinman, G. M., and Neitzel, J. E. (2020). Excising culture history from contemporary archaeology. Journal of Anthropological Archaeology 60: 101230.

Fernández-Götz, M. (2014a). Reassessing the oppida: The role of power and religion. Oxford Journal of Archaeology 33: 379-394.

Fernández-Götz, M. (2014b). Understanding the Heuneburg: A biographical approach. In FernándezGötz, M., Wendling, H., and Winger, K. (eds.), Paths to Complexity: Centralisation and Urbanisation in Iron Age Europe, Oxbow, Oxford, pp. 24-34.

Fernández-Götz, M. (2020). Migrations in Iron Age Europe: A comparative view. In Halkon, P. (ed.), The Arras Culture of Eastern Yorkshire: Celebrating the Iron Age, Oxbow, Oxford, pp. 179-199.

Fernández-Götz, M., and Ralston, I. (2017). The complexity and fragility of Early Iron Age urbanism in west-central temperate Europe. Journal of World Prehistory 30: 259-279.

Fischer, F. (1995). The early Celts of west central Europe: The semantics of social structure. In Arnold, B., and Blair Gibson, D. (eds.), Celtic Chiefdom, Celtic State: The Evolution of Complex Social Systems in Prehistoric Europe, Cambridge University Press, Cambridge, pp. 34-40.

Fokkens, H. (1998). Drowned Landscape: The Occupation of the Western Part of the Frisian-Drenthian Plateau, 4400 BC-AD 500, Van Gorcum, Assen.

Fontijn, D., and Fokkens, H. (2007). The emergence of Early Iron Age 'chieftain's graves' in the southern Netherlands: Reconsidering transformations in burial and depositional practices. In Haselgrove, C., and Pope, R. (eds.), The Earlier Iron Age in Britain and the Near Continent, Oxbow, Oxford, pp. 351-373.

Fox, A. (1953). Hill-slope forts and related earthworks in south-west England and south Wales. Archaeological Journal 109: 1-22 
Frankenstein, S., and Rowlands, M. J. (1978). The internal structure and regional context of Early Iron Age society in south-western Germany. Bulletin of the Institute of Archaeology (London) 15: 73-112.

Freeman, P. (2001). Classical ethnography and the Celts: Can we trust the sources? Proceedings of the Harvard Celtic Colloquium 20/21: 22-28.

Frieman, C. J., Teather, A., and Morgan, C. (2019). Bodies in motion: Narratives and counter narratives of gendered mobility in European later prehistory. Norwegian Archaeological Review 52: 148-169.

Furholt, M. (2018). Massive migrations? The impact of recent aDNA studies on our view of third millennium Europe. European Journal of Archaeology 21: 159-191.

Gera, D. L. (1997). Warrior Women: The Anonymous Tractatus de Mulieribus, Brill, Leiden.

Gero, J. M. 1983. Gender bias in archaeology: A cross-cultural perspective. In Gero, J. M., Lacy, D. M., and Blakey, M. L. (eds.), The Socio-Politics of Archaeology, University of Massachusetts, Amherst, pp. 51-57.

Gero, J. M., and Conkey, M. W. (1991). Engendering Archaeology: Women and Prehistory, Blackwell, Oxford.

Gerritsen, F. 2003. Local Identities: Landscape and Community in the Late Prehistoric Meuse-DemerScheldt Region, Amsterdam University Press, Amsterdam.

Gilchrist, R. (1999). Gender and Archaeology: Contesting the Past, Routledge, London.

Giles, M. (2012). A Forged Glamour: Landscape, Identity and Material Culture in the Iron Age, Windgather, Oxford.

Giles, M., Green, V., and Peixoto, P. (2020). Wide connections: Women, mobility and power in Iron Age East Yorkshire. In Halkon, P. (ed.), The Arras Culture of Eastern Yorkshire: Celebrating the Iron Age, Oxbow, Oxford, pp. 47-66.

Godard, C. (2013). L'implantation des habitations circulaires en Bretagne et an Normandie à l'âge du Fer: Un échange d'hommes et de savoirs. Revue Archéologique de l'Ouest 30: 165-186.

Green, M. J. (ed.) (1995). The Celtic World, Routledge, London.

Green, S. (2008), Diet and status at the Iron Age site of Mill Hill: Carbon and nitrogen stable isotope evidence. B.A. thesis, Department of Archaeology, University of Cambridge, Cambridge.

Gwilt. A., and Haselgrove, C. (eds.) (1997). Reconstructing Iron Age Societies, Oxbow, Oxford.

Hakenbeck, S. (2018). Infant head shaping in the first millennium AD. In Crawford, S., Hadley, D. M., and Shepherd, G. (eds.), Oxford Handbook for the Archaeology of Childhood, Oxford University Press, Oxford, pp. 483-504.

Hakenbeck, S. (2019). Genetics, archaeology and the far right: An unholy Trinity. World Archaeology 51: 517-527.

Haselgrove, C. (1986). An Iron Age community and its hillfort: The excavation at Danebury, Hampshire, 1969-79: A review. Archaeological Journal 143: 363-369.

Hawkes, C. F. C., and Dunning, G. C. (1931). The Belgae of Gaul and Britain. The Antiquaries Journal 87: $150-335$.

Hedeager, L. (1992). Iron Age Societies: From Tribe to State in Northern Europe, 500 BC to AD 700 , Blackwell, Oxford.

Hedenstierna-Jonson, C., Kjellström, A., Zachrisson, T., Krzewińska, M., Sobrado, V., Price, N., et al. 2017. A female Viking warrior confirmed by genomics. American Journal of Physical Anthropology 164: 853-860.

Heyd, V. (2017). Kossinna's smile. Antiquity 91: 348-359.

Hill, J. D. (1989). Re-thinking the Iron Age. Scottish Archaeological Review 6: 16-24.

Hill, J. D. (1995). How should we study Iron Age societies and hillforts? A contextual study from southern England. In Hill, J. D., and Cumberpatch, C. G. (eds.), Different Iron Ages: Studies on the Iron Age in Temperate Europe, BAR international series 602, Tempus Repartum, Oxford, pp. 45-66.

Hill, J. D. (1996). Hill-forts and the Iron Age of Wessex. In Champion, T. C., and Collis, J. R. (eds.), The Iron Age in Britain and Ireland: Recent Trends, Collis, Sheffield, pp. 95-116.

Hill, J. D. (2006). Are we any closer to understanding how later Iron Age societies worked (or did not work)? In Haselgrove, C. (ed.), Celtes et gaulois: L'archéologie face à l'histoire: Les mutations de la fin de l'âge du Fer, Collection Bibracte 12/4, Glux-en-Glenne, pp. 169-179.

Hill, J. D. (2011). How did British middle and late pre-Roman Iron Age societies work (if they did)? In Moore, T., and Armada, X.-L. (eds.), Atlantic Europe in the First Millennium BC: Crossing the Divide, Oxford University Press, Oxford, pp. 241-263. 
Hingley, R. 1984. Towards social analysis in archaeology: Celtic society in the Upper Thames Valley. In Cunliffe, B., and Miles, D. (eds.), Aspects of the Iron Age in Central Southern Britain, Committee for Archaeology Monograph No. 2, Oxford University, Oxford, pp. 72-88.

Hinton, P. (1986). An analysis of burial rites at Münsingen-Rain: An approach to the study of Iron Age society. Actes VIII Colloque Association Française pour l'Etude de l'Age du Fer, Revue Aquitania (Supplément 1), Bordeaux, pp. 351-368.

Hobden, F. (2016). The Symposion in Ancient Greek Society and Thought, Cambridge University Press, Cambridge.

Hodder, I. (1982). The Present Past, Batsford, London.

Hodder, I. (1986). Reading the Past, Cambridge University Press, Cambridge.

Hodson, F. R. (1964). Cultural groupings within the British pre-Roman Iron Age, Proceedings of the Prehistoric Society 30: 99-110.

Hodson, F. R. (1990). Hallstatt: The Ramsauer Graves: Quantification and Analysis, RGZM Monographien 16, Römisch-Germanisches Zentralmuseum, Mainz.

Hornblower, S., Spawforth, A., and Eidinow, E. (2012). The Oxford Classical Dictionary, 4th ed., Oxford University Press, Oxford.

James, S. (1993). Exploring the World of the Celts, Thames and Hudson, London.

James, S. (1999). The Atlantic Celts: Ancient People or Modern Invention? British Museum Press, London.

Jay, M., and Montgomery, J. (2020). Isotopes and chariots: Diet, subsistence and origins of Iron Age people from Yorkshire. In Halkon, P. (ed.), The Arras Culture of Eastern Yorkshire: Celebrating the Iron Age, Oxbow, Oxford, pp. 85-100.

Joffroy, R. (1954). Das Oppidum Mont-Lassois, Gemeinde Vix, Dep. Cote d'Or. Germania 32: 59-65.

Joffroy, R. (1960). L'oppidum de Vix et la civilization Hallstattienne finale, Université de Dijon, Paris.

Karl, R. (2004). Celtoscepticism: A convenient excuse for ignoring non-archaeological evidence? In Sauer, E. W. (ed.), Archaeology and History: Breaking Down the Borders, Routledge, London, pp. $185-199$.

Karl, R. (2008). Random coincidences? Or: the return of the Celtic to Iron Age Britain. Proceedings of the Prehistoric Society 74: 69-78.

Karl, R. (2012). The Celts from everywhere and nowhere: A re-evaluation of the origins of the Celts and the emergence of Celtic cultures. In Cunliffe, B., and Koch, J. T. (eds.), Celtic from the West: Alternative Perspectives from the Archaeology, Genetics, Language and Literature, Oxbow, Oxford, pp. 39-64.

Karl, R., and Stifter, D. (eds.) (2007). The Celtic World: Critical Concepts in Historical Studies, vol. 1: Theory in Celtic Studies, Routledge, London.

Kenyon, K. (1952). A survey of the evidence concerning the chronology and origins of Iron Age A in southern and midland England. London Institute of Archaeology Annual Report 8: 29-78.

Kiesslich, J., Neuhuber, F., Meyer, H. J., Baur, M. P., and Leskovar, J. (2005). DNA analysis on biological remains from archaeological findings: Sex identification and kinship analysis on skeletons from Mitterkirchen, Upper Austria. In Karl, R., and Leskovar, J. (eds.), Interpretierte Eisenzeiten 1, Oberösterreichisches Landesmuseum, Linz, pp. 141-154.

Kimmig, W. (1969). Zum problem späthallstättischer Adelssitze. In Otto, K.-H., and Herrmann, J. (eds.), Siedlung, Burg und Stadt: Studien zu ihren Anfängen (Festschrift für Paul Grimm), Deutsche Akademie der Wissenschaften zu Berlin, Berlin, pp. 95-113.

Koch, J., Karl, R., Minard, A., and Ó’ Faoláin, S. (2007). An Atlas for Celtic Studies: Archaeology and Names in Ancient Europe and Early Medieval Ireland, Britain and Brittany, Oxbow, Oxford.

Koch, J. (2009). Tartessian: Celtic in the South-West at the Dawn of History, Oxbow, Oxford.

Koch, J. (2011). Tartessian 2: The Inscription of Mesas Do Castelinho Ro and the Verbal Complex Preliminaries to Historical Phonology, Oxbow, Oxford.

Koch, J. (2019). Celtic from the West meets linguistics and genetics. In Cunliffe, B. W., and Koch, J. T. (eds.), Exploring Celtic Origins: New Ways Forward in Archaeology, Linguistics, and Genetics, Oxbow, Oxford, pp. 19-37.

Krausse, D. (1999). Der "Keltenfürst" von Hochdorf: Dorfältester oder Sakralkönig? Anspruch und Wirklichkeit der sog. kulturanthropologischen Hallstatt-Archäologie. Archäologisches Korrespondenzblatt 29: 339-358.

Krausse, D., Fernández-Götz, M., Hansen, L., and Kretschmer, I. (2016). The Heuneburg and the Early Iron Age Princely Seats: First Towns North of the Alps, Archaeolingua, Budapest.

Kristiansen, K. (1998). Europe before History, Cambridge University Press, Cambridge. 
Kruta, V. (1976). Les celtes, Presses Universitaires de France, Paris.

Kruta, V. (1997). In search of the ancient Celts. In Moscati, S., Frey, O.-H., Kruta, V., Raftery, B., and Szabó, M. (eds.), The Celts, Rizzoli, New York, pp. 22-29.

Kruta, V. (2005). The Celts: History and Civilisation, Hachette, London.

Lane Fox, A. H. (1868). An examination into the character and probable origin of the hill forts of Sussex. Archaeologia 42: 27-52.

Latour, B. (2005). Reassembling the Social: An Introduction to Actor-Network-Theory, Oxford University Press, Oxford.

MacCormack, C., and Strathern, M. (eds.) (1980). Nature, Culture and Gender, Cambridge University Press, Cambridge.

McKinley, J. I., Leivers, M., Schuster, J., Marshall, P., Barclay, A. J., and Stoodley, N. (2014). Cliffs End Farm, Isle of Thanet, Kent, Wessex Archaeology, Salisbury.

Mead, M. (1935). Sex and Temperament in Three Primitive Societies, Morrow, New York.

Mead, M. (1950). Male and Female, Penguin, Harmondsworth.

Megaw, J. V. S., and Megaw, R. M. (1989). Celtic Art: From Its Beginnings to the Book of Kells, Thames and Hudson, London.

Megaw, J. V. S., and Megaw, R. M. (1992). The Celts: The first Europeans? Antiquity 66: 254-260.

Megaw, J. V. S., and Megaw, R. M. (1996). Ancient Celts and modern ethnicity. Antiquity 70: 175-181.

Milcent, P.-Y. (2003). Statut et fonctions d'un personage féminin hors norme. In Rolley, C. (ed.), $L a$ tombe princière de Vix, Éditions Picard, Paris, pp. 311-327.

Milcent, P.-Y. (2004). Le premier âge du Fer en France centrale, Mémoire 34, Société Préhistorique Française, Paris.

Milcent, P.-Y. (2014). Hallstatt urban experience before the Celtic oppida in central and eastern Gaul: Two cases-studies: Bourges and Vix. In Fernández-Götz, M., Wendling, H., and Winger, K. (eds.), Paths to Complexity: Centralisation and Urbanisation in Iron Age Europe, Oxbow, Oxford, pp. 35-51.

Moore, T. (2017). Alternatives to urbanism? Reconsidering oppida and the urban question in Late Iron Age Europe. Journal of World Prehistory 30: 281-300.

Mortillet, G. (1871). Les gaulois de Marzabotto dans l'Apennin. Revue Archaéologique 22: 288-290.

Moscati, S., Frey, O.-H., Kruta, V., Raftery, B., and Szabó M. (eds.) (1997). The Celts, 2nd ed., Rizzoli, New York.

Nash, D. (1984). The basis of contact between Britain and Gaul in the late pre-Roman Iron Age. In Macready, S., and Thompson, F. H. (eds.), Cross-Channel Trade between Gaul and Britain in the Pre-Roman Iron Age, Society of Antiquaries, London, pp. 92-107.

Nash, D. (1985). Celtic territorial expansion and the Mediterranean world. In Champion, T. C., and Megaw, J. V. S. (eds.), Settlement and Society: Aspects of West European Prehistory in the First Millennium BC, Leicester University Press, Leicester, pp. 45-67.

Nash Briggs, D. (2003). Metals, salt, and slaves: Economic links between Gaul and Italy from the eighth to the late sixth centuries BC. Oxford Journal of Archaeology 22: 243-259.

Nash Briggs, D. (2007). Home truths from travellers' tales: On the transmission of culture in the European Iron Age. In Gosden, C., Hamerow, H., de Jersey, P., and Lock, G. (eds.), Communities and Connections: Essays in Honour of Barry Cunliffe, Oxford University Press, Oxford, pp. 15-29.

Oelze, V. M., Koch, J. K., Kupke, K., Nehlich, O., Zäuner, S., Wahl, J., et al. (2012). Multi-isotopic analysis reveals individual mobility and diet at the Early Iron Age monumental tumulus of Magdalenenberg, Germany. American Journal of Physical Anthropology 148: 401-421.

Pauli, L. (1972). Untersuchungen zur Späthallstattkultur in Nordwürrtemberg: Analyse eines Kleinraums im Grenzbereich zweier Kulturen, Hamburger Beiträge 2, Hamburg.

Pauli, L. (1980). Die herkunft der Kelten: Sinn und unsinn einer alten frage. In Pauli, L. (ed.), Die Kelten in Mitteleuropa: Kultur, Kunst, Wirtschaft, Salzburg, Salzburger Landesausstellung, pp. 16-24.

Pauli, L. (1994). Case studies in Celtic archaeology. In Kristiansen, K., and Jensen, J. (eds.), Europe in the First Millennium BC, Collis, Sheffield, pp. 67-79.

Pare, C. (1991). Fürstensitze: Celts and the Mediterranean world: Developments in the west Hallstatt culture in the 6th and 5th centuries BC. Proceedings of the Prehistoric Society 52: 183-202.

Pare, C. (1992). Wagons and Wagon-Graves of the Early Iron Age in Central Europe, Oxford University Committee for Archaeology, Oxford.

Pezron, P.-Y. (1703). L'antiquité de la nation et de la langues des celtes autrement appellez gaulois, Paris. 
Piggott, S. (1967). Celts, Saxons and Early Antiquaries: The O'Donnell Lecture 1966, Edinburgh University Press, Edinburgh.

Piggott, S. (1983). The Earliest Wheeled Transport: From the Atlantic Coast to the Caspian Sea, Thames and Hudson, London.

Pope, R. E. (2003). Circular Structures in North and Central Britain c. 2500 BC-AD 500, Ph.D. dissesrtation, Department of Archaeology, University of Durham, Durham.

Pope, R. E. (2007). Ritual and the roundhouse: A critique of recent ideas on domestic space in later British prehistory. In Haselgrove, C., and Pope, R. (eds.), The Earlier Iron Age in Britain and the Near Continent, Oxbow, Oxford, pp. 204-228.

Pope, R. E. (2011). Processual archaeology and gender politics: The loss of innocence. Archaeological Dialogues 18: 59-86.

Pope, R. E. (2015a). Review of 'The Celts: Blood, Iron and Sacrifice' - BBC2. History Today (October). Available at: http://www.historytoday.com/rachel-pope/celts-blood-iron-and-sacrifice.

Pope, R. E. (2015b). Bronze Age architectural traditions: Dates and landscapes. In Hunter, F., and Ralston, I. B. M. (eds.), Scotland in Later Prehistoric Europe, Society of Antiquaries of Scotland, Edinburgh, pp. 159-184.

Pope, R. E. (2018). Gender and society. In Wells, P. S., Rebay-Salisbury, K., and Haselgrove, C. (eds.), Oxford Handbook of the European Iron Age, Oxford University Press, Oxford (Oxford Handbooks Online) https://doi.org/10.1093/oxfordhb/9780199696826.013.4

Pope, R. E. (2020). Review of Cunliffe and Koch's Exploring Celtic Origins: New Ways Forward in Archaeology, Linguistics, and Genetics. Archaeological Journal 177: 421-422.

Pope, R. E., and Haselgrove, C. C. (2007). Characterising the Early Iron Age. In Haselgrove, C., and Pope, R. (eds.), The Earlier Iron Age in Britain and the Near Continent, Oxbow, Oxford, pp. 204-228.

Pope, R. E., and Ralston, I. B. M. (2011). Approaching sex and status in Iron Age Britain with reference to the nearer continent. In Moore, T., and Armada, X.-L. (eds.), Atlantic Europe in the First Millennium BC: Crossing the Divide, Oxford University Press, Oxford, pp. 371-414.

Pope, R. E., Mason, R. G., Hamilton, D., Rule, E., and Swogger, J. (2020). Hillfort gate-mechanisms: A contextual, architectural reassessment of Eddisbury, Hembury, and Cadbury hillforts. Archaeological Journal 177: 339-407.

Powell, T. G. E. (1958). The Celts, Thames and Hudson, London.

Powell, T. G. E. (1971). From Urartu to Gundestrup: The agency of Thracian metalwork. In Boardman, J., Smith, M. A., and Powell, T. G. E. (eds.), The European Community in Later Prehistory: Studies in Honour of C. F. C. Hawkes, Routledge, London, pp. 183-210.

Powell, T. G. E. (1976). The inception of the Iron Age in temperate Europe. Proceedings of the Prehistoric Society 42: 1-14.

Prosdocimi, A. L. (1984). Una nuova iscrizione Venetica da Oderzo con elementi Celtici. In Marzi Costagli, M. G., and Tamagno Perna, L. (eds.), Studi di Antichità in Onore di Guglielmo Maetzke, Vol. 2, Giorgio Bretschneider, Rome, pp. 423-442.

Prtak, E. J. (2019). Writing 'herstory' from the Molly Cotton Archive: How women's careers impacted mid20th century Iron Age studies. M.S. thesis, Department of Archaeology, Classics and Egyptology, University of Liverpool, Liverpool.

Rankin, D. (1996). Celts and the Classical World, Routledge, London.

Rebay-Salisbury, K. (2016). The Human Body in Early Iron Age Central Europe: Burial Practices and Images of the Hallstatt World, Routledge, London.

Rhŷs, J. 1882. Early Britain: Celtic Britain, Society for Promoting Christian Knowledge, London.

Richards, C., Bouman, W. P., and Barker, M.-J. (eds.) (2017). Genderqueer and Non-Binary Genders, Palgrave Macmillan, London.

Rolley, C. (ed.) (2003). La Tombe Princière de Vix, Picard/Société des Amis du Musée du Châtillonnais, Paris.

Roualet, P. (1997). The Marnian culture of Champagne. In Moscati, S., Frey, O.-H., Kruta, V., Raftery, B., and Szabó, M. (eds.) The Celts, 2nd ed., Rizzoli, New York, pp. 165-172.

Saini, A. (2019). Superior: The Return of Race Science, 4th Estate, London.

Samson, R. (ed.) (1990). The Social Archaeology of Houses, Edinburgh University Press, Edinburgh.

Sankot, P. (1997). The Celtic population of Bohemia in the fourth century BC. In Moscati, S., Frey, O.-H., Kruta, V., Raftery, B., and Szabó, M. (eds.), The Celts, 2nd ed., Rizzoli, New York, pp. 294-296. 
Sastre, I. (2011). Social inequality during the Iron Age: Interpretation models. In Moore, T., and Armada, X.-L. (eds.), Atlantic Europe in the First Millennium BC: Crossing the Divide, Oxford University Press, Oxford, pp. 264-284.

Scheeres, M., Knipper, C., Hauschild, M., Schönfelder, M., Siebel, W., Vitali, D., Pare, C., and Alt, K. W. (2013). Evidence for "Celtic migrations"? Strontium isotope analysis at the early La Tène (La Tène B) cemeteries of Nebringen (Germany) and Monte Bibele (Italy). Journal of Archaeological Science 40: 3611-3625.

Shipley, G. (2011). Pseudo-Skylax's Periplous: The Circumnavigation of the Inhabited World, Phoenix, Bristol.

Shrimpton, G. S. (1991). Theopompus the Historian, McGill-Queen's University Press, London.

Sims-Williams, P. (1998). Celtomania and Celtoscepticism. Cambrian Medieval Celtic Studies 36: 1-35.

Sims-Williams, P. (2016). The location of the Celts according to Hecataeus, Herodotus, and other Greek writers. Études Celtiques 42: 7-32.

Sims-Williams, P. (2017). The earliest Celtic ethnography. Zeitschrift für Celtische Philologie 64: 421-442.

Sims-Williams, P. (2020). An alternative to 'Celtic from the east' and 'Celtic from the west.' Cambridge Archaeological Journal 30: 1-19.

Spindler, K. 1983. Die Frühen Kelten, Reclam, Stuttgart.

Stopford J. (1987). Danebury: An alternative view. Scottish Archaeological Review 4: 70-75.

Strathern, M. (2020). Relations: An Anthropological Account, Duke University Press, London.

Thierry, A. (1827). Histoire de Gaulois, Paris.

Tierney, J. J. (1960). The Celtic ethnography of Posidonius. Proceedings of the Royal Irish Academy: Archaeology, Culture, History, Literature 60: 189-275.

Trémeaud, C. (2018). Genre et hiérarchisation dans le monde nord-alpin, aux âges du Bronze et du Fer, BAR International Series 2912, Archaeopress, Oxford.

Trémeaud, C. (2019). Tracing gender in funerary data: The case study of elite graves in the north-alpine complex (Late Bronze Age to La Tène B). In Koch, J., and Kirleis, W. (eds.), Gender Transformations in Prehistoric and Archaic Societies, Sidestone, Leiden, pp. 275-293.

Trigger, B. (1984). A History of Archaeological Thought, Cambridge University Press, Cambridge.

Turek, J. (2016). Sex, transsexuality and archaeological perception of gender identities. In Casella, E. C., and Fowler, C. (eds.), The Archaeology of Plural and Changing Identities, Plenum, New York, pp. 55-71.

Veit, U. (2000). König und Hohepriester? Zur These der sakralen Gründung der Herrschaft in der Hallstattzeit. Archäologisches Korrespondenzblatt 30: 549-568.

Verger, S. (1995). De Vix à Weiskirchen: La transformation des rites funéraires aristocratiques en Gaule du nord et de l'est au Ve siècle avant J.-C. Mélanges de l'École Française de Rome (Antiquité) 107: $331-458$.

Verger, S., and Pernet, L. (eds.) (2013). Une odyssée Gauloise: Parures de femmes à l'origine des premiers échanges entre la Grèce et la Gaule, Collection Archéologie de Montpellier Agglomération 4, Éditions Errance, Arles.

Vitali, D. (1997). The Celts in Italy. In Moscati, S., Frey, O.-H., Kruta, V., Raftery, B., and Szabó, M. (eds.), The Celts, Rizzoli, New York, pp. 230-247.

Walley, M. (2019). Incorporating Nonbinary Gender into Inuit Archaeology: Oral Testimony and Material Inroads, Routledge, London.

Webley, L. 2008. Iron Age Households: Structure and Practice in Western Denmark, 500 BC-AD 200, Jutland Archaeological Society Publications, Hoejbjerg.

Wheeler, R. E. M. 1921. Roman and native in Wales: An imperial frontier problem, Transactions of the Honourable Society of Cymmrodorion 1920-1921: 40-96.

Wylie, A. (1985). The reaction against analogy. Advances in Archaeological Method and Theory 8: 63-111.

\section{Bibliography of Recent Literature}

Arnold, B. (2011). The illusion of power, the power of illusion: Ideology and the concretization of social difference in Early-Iron Age Europe. In Bernbeck, R., and McGuire, R. H. (eds.), Ideologies in Archaeology, University of Arizona Press, Tucson, pp. 151-172. 
Arnold, B. (2012). The Vix Princess redux: A retrospective on European Iron Age gender and mortuary studies. In Prados Torreira, L. (ed.), La arqueología funeraria desde una perspectiva de género, UA Ediciones, Madrid, pp. 211-232.

Arnold, B. (2016). Belts vs. blades: The binary bind in Iron Age mortuary contexts in southwest Germany. Journal of Archaeological Method and Theory 23: 831-853.

Farley, J., and Hunter, F. (2015). Celts: Art and Identity, British Museum Press, London.

Green, M. J. (1997). Exploring the World of the Druids, Thames and Hudson, London.

Haselgrove, C. C., and Pope, R. E. (eds.) (2007). The Earlier Iron Age in Britain and the Near Continent, Oxbow, Oxford.

Jordan, A. M. (2016). Her mirror, his sword: Unbinding binary gender and sex assumptions in Iron Age British mortuary traditions. Journal of Archaeological Method and Theory 23: 870-899.

Lejars, T. (2013). La Tène: La collection Schwab (Bienne, Suisse), La Tène, un site, un mythe 3, Vols. 1-2, Cahiers d'Archéologie Romande 140-141, Cahiers d'Archéologie Romande, Lausanne.

Piggott, S., and Daniel, G. (1951). A Picture Book of Ancient British Art, Cambridge University Press, Cambridge.

Rieckhoff, S., and Biel, J. (2001). Die Kelten in Deutschland, Theiss, Stuttgart.

Schwab, R., Milcent, P.-Y., Armbruster, B., and Pernicka, E. (eds.) (2018). Early Iron Age Gold in Celtic Europe: Society, Technology, and Archaeometry, Proceedings of the International Congress Held in Toulouse, France, 11-14 March 2015, VML GmbH, Rahden/Westf.

Sims-Williams, P. (2006). Ancient Celtic Place-Names in Europe and Asia Minor, Blackwell, Oxford.

Wells, P., Rebay-Salisbury, K., and Haselgrove, C. (eds.) (2018). The Oxford Handbook of the European Iron Age, Oxford University Press, Oxford (Oxford Handbooks Online) https://doi.org/10.1093/oxfor dhb/9780199696826.001.0001

Publisher's Note Springer Nature remains neutral with regard to jurisdictional claims in published maps and institutional affiliations. 